\title{
ENCUESTA SOBRE LA CUESTIÓN CATALANA
}

\section{PRESENTACIÓN}

Nuestra revista ha afrontado siempre el estudio de los problemas de alcance jurídico-constitucional, aunque los mismos estuviesen situados en terrenos de dureza innegable, por lo que ni la dirección ni los miembros del equipo de redacción han dudado nunca en abordar los múltiples y reiterados conflictos que han jalonado la vigencia del Título VIII de nuestra Constitución.

Ello ha sido así desde los primeros balbuceos de «Teoría y Realidad Constitucional», en cuyo primer número se recoge una recensión de la STC 91/1998 — de la que fue ponente el profesor Jiménez de Parga — en que nuestro alto Tribunal niega que se hubiese producido una invasión del ámbito competencial autonómico contemplado en el artículo 20.1 del Estatuto de Autonomía de Cataluña.

Siendo aún más clara prueba de esa especial preocupación nuestra el dedicar nuestro número dos, con carácter monográfico a la temática Lenguas y Constitución, publicando íntegramente, entre otros textos, los cuatro dictámenes solicitados por el Defensor del Pueblo sobre la posible inconstitucionalidad de la Ley 1/1998, de 7 de enero, de Política lingüística del Parlamento de la Generalidad de Cataluña y emitidos por los profesores Tomás Ramón Fernández, Antonio López Pina, Sebastián Martín-Retortillo y Jesús Prieto de Pedro, que desembocaban unánimemente en la conclusión de que dicha Ley autonómica era inconstitucional, sin que sea preciso recordar que ni el Gobierno ni el Defensor del Pueblo ni ningún Grupo de parlamentarios de ninguna de las Cámaras interpusiese recurso de inconstitucionalidad ante el supremo intérprete de la Constitución.

Desde el mismo particular interés por verter luz sobre la crecientemente compleja y preocupante realidad de nuestro sistema autonómico, esta modesta revista dedicó la encuesta que sirvió de pórtico a su número tres a ofrecer la oportunidad a cinco prestigiosos catedráticos de nuestra disciplina — Francesc de Carreras, Javier Corcuera, José Juan González Encinar, Pablo Pérez Tremps y Francisco Rubio Llorente- de verter su sabio criterio al hilo de preguntas sobre si era aún posible pensar en un tránsito de nuestro Estado autonómico hacia un Estado federal, si se observaban actitudes coherentes con las exigencias de la lealtad constitucional, si había posicionamientos nacionalistas que colisionaban con los man- 
datos constitucionales, sobre las dinámicas que generaban en las últimas legislaturas los «gobiernos recostados en el apoyo parlamentario cotidiano de los grupos nacionalistas», sobre si se había incrementado la influencia de las fuerzas nacionalistas en la jurisprudencia del Tribunal Constitucional... y así sucesivamente en los números ulteriores de esta publicación.

En efecto, en nuestro número doble 10-11, en 2002, convocamos a seis colegas a contestar a otras tantas preguntas sobre el Derecho de Autodeterminación, cuyas dos últimas preguntas eran: ¿Entiende que plantear una consulta en un territorio determinado sobre la existencia misma del Derecho de Autodeterminación supondría ya la vigencia de tal derecho, porque implicaría la afirmación del pueblo consultado como poder soberano, sujeto de un nuevo poder constituyente? y ¿Cuál sería la actuación correcta del Estado desde el ángulo del Derecho constitucional, ante una iniciativa de ciertas instituciones (como por ejemplo órganos de Comunidades Autónomas) tendente a posibilitar el ejercicio del llamado derecho de autodeterminación?

Y en 2011 dedicamos nuestro número 27, con carácter monográfico al estudio de la STC 31/2010 sobre el nuevo Estatuto de Cataluña.

En 2015, el curso obvio de la vida política en Cataluña no era desconocible por ningún medio de comunicación, ni era precisa una capacidad de análisis profundo para deducir que el nacionalismo catalán pretendía abordar una fase soberanista para abordar finalmente la escisión de Cataluña respecto del Estado. Ello nos conducía a dedicar un nuevo número monográfico, que es el que el lector tiene en sus manos, sobre tan grave cuestión, que debíamos introducir con una encuesta a la que invitaríamos a responder a un grupo particularmente cualificado de catedráticos de Derecho Constitucional, con una presencia significativa de colegas de universidades de Cataluña, de diversas sensibilidades en esta materia.

«Teoría y Realidad Constitucional» quiere agradecer expresa y muy sinceramente a todos los profesores a que hemos invitado el que sin excepción hayan aceptado participar y nos hayan remitido unas amplias respuestas de lectura casi imprescindible para cuantos compartimos la docencia del Derecho Constitucional en nuestras aulas. Así mismo deseamos constatar nuestra confianza acerca de que en los distintos ámbitos académicos potenciemos el esfuerzo por hacer aportaciones intelectuales lúcidas a un problema cuya gravedad nadie puede ya ni desconocer ni negar.

\section{CUESTIONES}

1. ¿En qué sentido cree que el Título VIII de nuestra Constitución ha operado como integrador de Cataluña en el conjunto de España y en qué medida su carácter abierto cree que ha facilitado el proceso de acumulación de poder y de competencias con la vista quizás puesta en una meta de secesión? 
2. En su opinión, ¿qué ha podido significar en el proceso soberanista el Estatuto de Autonomía de Cataluña de 2006? ¿Y la STC 31/2010 que resolvió el recurso de inconstitucionalidad presentado desde la oposición?

3. ¿Qué analogías y diferencias observa entre el proceso promovido por el nacionalismo catalán y el seguido por el nacionalismo de Quebec o de Escocia? ¿Cree que de esas experiencias debemos aprender algo?

4. ¿Qué valoración técnico-jurídica le merece el llamado derecho a decidir? ¿Y la vía de las denominadas elecciones plebiscitarias?

5. ¿Qué comentarios desea usted hacer a los pronunciamientos del Tribunal Constitucional sobre los pasos que el Govern y el Parlament han dado en esta andadura? ¿Y sobre los dictámenes del Consell de Garantías Estatutarias?

6. ¿Cree usted aplicable y útil para los supuestos indicados en las preguntas inmediatamente anteriores el que el Estado actuase al amparo de las previsiones del artículo 155 CE?

7. ¿Considera que algún tipo de reforma constitucional o estatutaria sería capaz de potenciar la integración de Cataluña, satisfaciendo, cuando menos, a parte de quienes apoyan la opción «soberanista? ¿Querría usted dejarnos constancia de alguna otra reflexión o sugerencia sobre la fase presente de la cuestión catalana?

8. Como constitucionalista ¿qué consideraciones quiere aportarnos sobre una hipotética declaración de independencia unilateral por parte del Parlament tras las llamadas elecciones autonómicas plebiscitarias? ¿Y sobre una posible subsiguiente redacción y aprobación de una Constitución catalana?

\section{ENCUESTADOS}

ENOCH ALBERTÍ ROVIRA, Catedrático de Derecho Constitucional, Universidad de Barcelona.

ROBERTO L. BLANCO VALDÉS, Catedrático de Derecho Constitucional, Universidad de Santiago de Compostela.

ENRIC FOSSAS ESPADALER, Catedrático de Derecho Constitucional, Universidad Autónoma de Barcelona.

TERESA FREIXES SANJUAN, Catedrática de Derecho Constitucional, Universidad Autónoma de Barcelona.

JAVIER GARCÍA FERNÁNDEZ, Catedrático de Derecho Constitucional, Universidad Complutense de Madrid.

JOSÉ ANTONIO MONTILLA MARTOS, Catedrático de Derecho Constitucional, Universidad de Granada.

MIGUEL SATRÚSTEGUI GIL-DELGADO, Profesor Titular de Derecho Constitucional, Universidad Carlos III de Madrid.

EDUARDO VIRGALA FORURIA, Catedrático de Derecho Constitucional, Universidad del País Vasco. 


\section{RESPUESTAS}

1. ¿En qué sentido cree que el Titulo VIII de nuestra Constitución ba operado como integrador de Cataluña en el conjunto de España y en qué medida su carácter abierto cree que ha facilitado el proceso de acumulación de poder y de competencias con la vista quizás puesta en una meta de secesión?

\section{ENOCH ALBERTÍ ROVIRA}

A mi juicio, la Constitución de 1978 constituyó un intento muy serio de resolver la cuestión catalana y, más en general también, el problema de la articulación territorial española. Baso esta afirmación en dos hechos relevantes relativos al tratamiento de la cuestión territorial en la Constitución de 1978: primero, el reconocimiento, en su Título Preliminar, de las nacionalidades y de las regiones. Tal reconocimiento, efectuado en el mismo frontispicio del texto constitucional, daba paso - $\mathrm{o}$ al menos así se podía razonablemente entender y en esta convicción se situaron muchos sectores políticos-a una nueva concepción de la unidad estatal, basada ahora en la diversidad territorial y la pluralidad de poderes. Este reconocimiento tenía sin duda importancia histórica, pues rompía el patrón sobre el que se había construido el Estado constitucional en España en los últimos doscientos años, de corte unitario, uniformista y fuertemente centralista, sólo exceptuado fugazmente en las experiencias fallidas de la Primera y la Segunda Repúblicas. Y, segundo, el establecimiento en la Constitución de un modelo territorial abierto y flexible. Porque, en efecto, la Constitución no fija una estructura territorial del poder única y uniforme. Y ni siquiera puede decirse que fije, directamente, una estructura territorial nueva. Lo que realmente hace la Constitución es, a partir del reconocimiento de las nacionalidades y las regiones (sin determinar cuáles sean) establecer las reglas para permitir la creación de unas nuevas entidades territoriales, que pueden ser diversas en su organización (art. 152 CE) y en sus competencias (art. 148 y 149 CE), remitiéndose para ello a normas posteriores de naturaleza y posición singulares, como son los estatutos de autonomía. Este carácter abierto y flexible es, a mi juicio, la clave del sistema territorial de la Constitución de 1978, que le otorga (u otorgó inicialmente) una capacidad de adaptación a las diversas realidades territoriales existentes en España, cuyo tratamiento uniforme, con un único molde, hubiera resultado imposible. La clave del consenso constitucional en esta materia tan problemática, y en la que los diversos partidos políticos partían de posiciones muy alejadas, residió precisamente en esta apertura y flexibilidad, en la capacidad de ofrecer soluciones diferenciadas.

Esta flexibilidad y apertura se muestran no sólo en el momento de la creación inicial de la nueva estructura territorial y de la configuración de las nuevas entidades, sino también en la capacidad de evolución —igualmente diferenciada—que se otorga al sistema, especialmente reflejada de forma expresa en la Constitución en las previsiones acerca de las posibilidades de modificar las competencias asumi- 
das inicialmente por las Comunidades Autónomas (art. 148.2 y $150 \mathrm{CE}$ ), pero también, de forma implícita pero igualmente clara, en la posibilidad de reformar en el futuro los propios estatutos de autonomía de las comunidades, que podrían evolucionar, en su caso, dentro de un marco constitucional muy general y abierto.

Esta configuración del modelo territorial, basada en una Constitución que establece un marco general y flexible y unos estatutos de autonomía particulares para las nuevas entidades territoriales, que pueden ser así configuradas de forma diferenciada, proporciona al sistema una gran complejidad, pero, como he dicho, también le ofrece una gran capacidad de adaptación a situaciones y realidades muy diversas. Uno de los problemas esenciales que, a mi juicio, se ha producido a lo largo del desarrollo del Estado autonómico es que no se ha gestionado adecuadamente esta complejidad y, de la forma en que se ha hecho, se ha sacrificado la capacidad de adaptación del sistema a las distintas realidades existentes.

En relación a la segunda parte de la cuestión planteada, no creo que el carácter abierto del modelo territorial inicialmente previsto en la Constitución haya sido aprovechado para acumular competencias «con la vista quizás puesta en una meta de secesión», como reza el enunciado que se formula. Creo que este enunciado expresa un juicio erróneo sobre la realidad. Si se observa la evolución de las posiciones llamadas soberanistas o independentistas en Cataluña puede comprobarse cómo éstas han crecido de forma significativa en los últimos 6 años, pasando de un 15-20\%, aproximadamente (nivel bastante estable desde la transición) al 48\%, al menos, en las elecciones al Parlamento de Cataluña de septiembre de 2015. Igualmente, el Gobierno de la Generalitat nunca sostuvo, hasta el año 2012, posiciones soberanistas. Por tanto, creo que no es acertada una visión que entienda que existía ya, desde los inicios del Estado autonómico, una cuasi-mayoría social soberanista / independentista, y unas instituciones que políticamente le correspondieran, que estuvieran a la espera de acumular poderes para plantear directamente la secesión. Creo que más bien lo que se ha producido es una pérdida, súbita pero con profundas raíces, de confianza en el Estado autonómico, a raíz esencialmente del fracaso del Estatuto de autonomía de 2006 (largo proceso interno de negociación y aprobación, nueva negociación en las Cortes Generales con importantes modificaciones, $y$, finalmente, sentencia del Tribunal Constitucional que en realidad lo invalida) y del fuerte movimiento re-centralizador que se ha desarrollado desde entonces, que ha llevado a amplios sectores sociales y políticos al convencimiento de que lo que quedaba realmente invalidado era el Estado autonómico en sí, al menos tal como lo concebían hasta el momento, fracasando con ello el intento, ya problemático pero en el que habían creído, de la Constitución de 1978.

\section{ROBERTO BLANCO VALDÉS}

La mejor prueba de que el Título VIII de la Constitución operó en su momento, y, con posterioridad, durante un largo período de tiempo, como un ins- 
trumento jurídico y político integrador del nacionalismo catalán —lo que me parece, en el contexto de la pregunta, más correcto que hablar de Cataluña- reside en el hecho de que la Constitución de 1978 se aprobó en las Cortes Constituyentes con un apoyo muy mayoritario por parte de los diputados catalanes. De los 47 elegidos en total en las provincias de Barcelona, Tarragona, Lérida y Gerona en los comicios de 15 de junio de 1977, 45 (el 96\%) votaron a favor del texto constitucional (los del PSC, PSUC, UCD, PDPC, UDC y CC-AP) y sólo 2 (el de Esquerra y uno de Pacto Democrático por Cataluña, que representaban un exiguo $4 \%$ de la representación parlamentaria catalana) optaron por la abstención. Si tal abrumadora mayoría se mide en término de votos, los datos no son, como es obvio, menos concluyentes: con un participación en las elecciones a Cortes Constituyentes de casi el $80 \%$ del cuerpo electoral, los sufragios de los seis partidos del sí representaron en conjunto el 89,9\% frente al 4,7\% de las fuerzas de la abstención, defendida sólo por Esquerra. En plena coherencia con ese resultado, el apoyo a la Constitución fue amplísimo, igualmente, en el referéndum de ratificación de la ley fundamental, pues mientras la media nacional del sí sobre voto válido alcanzó un porcentaje del 88,5\%, en Cataluña se elevó hasta el 90,1\%, sólo por debajo de los porcentajes obtenidos en Andalucía, Murcia y Canarias. Por tanto, decir que Cataluña apoyó masivamente la Constitución es una descripción precisa de lo que entonces ocurrió. Ese apoyo al sistema autonómico se mantuvo, al menos aparentemente, a lo largo de casi tres décadas, durante las cuales $\mathrm{CiU}$ no planteó ni la necesidad de una reforma estatutaria (Pujol hablaba todavía al final de su mandato de una lectura del Estatuto en clave catalanista, es decir, más favorable a la descentralización) ni mucho menos una superación del marco autonómico en el camino de la autodeterminación. Es verdad que hoy disponemos de muchos elementos que permiten constatar que los nacionalistas impulsaron desde muy pronto un proceso de construcción nacional (lo que ellos mismos llamaban fer país) y es verdad igualmente que a partir de la segunda década del siglo XxI tal proceso iba a desembocar en ese ya indisimulado fer estat en que ahora estamos y al que aquel previo fer país acabó por servirle en gran medida de soporte político de masas. Pero, ello constatado, lo cierto es que sólo desde una lectura manipuladora del pasado puede sostenerse que el sistema autonómico no supuso una integración del nacionalismo en el marco constitucional: los nacionalistas apoyaron ese marco, se beneficiaron de él gobernando ininterrumpidamente Cataluña desde 1980 hasta 2003 y sólo a partir de 2010, cuando la competencia con entre CIU y ERC pasó a ser un cuestión central para la primera de esas fuerzas, el hasta entonces llamado (probablemente mal llamado) nacionalismo moderado comenzó una deriva soberanista que ha acabado en el desafío al orden constitucional en que hoy estamos.

En cuanto a la segunda cuestión que se plantea en la pregunta, la respuesta, a mi juicio, no puede ser más que positiva. Uno de los principales defectos del Título VIII de la Constitución es su carácter abierto, lo que se deriva, en primer lugar, del defectuoso sistema de reparto de competencias contenido en las dos 
listas de los artículos 148 y 149 de la ley fundamental, reparto que, según es conocido, sólo es efectivo a través de la concreción que lleva a cabo cada Estatuto, lo que complica extraordinariamente el funcionamiento práctico del sistema y aumenta el protagonismo del Tribunal Constitucional, hasta extremos insoportables, para que éste pueda cumplir adecuadamente su importante función como supremo intérprete de la Constitución. Junto a ello, la disparatada previsión del artículo 150.2, en relación con las leyes de delegación o transferencia de competencias, ha puesto en manos de la mayoría parlamentaria un mecanismo que se presta a todo tipo de interpretaciones abusivas de las previsiones de la Constitución y que, de hecho desconstitucionaliza en gran parte el régimen de reparto de competencias dispuesto en nuestra ley fundamental. Las cosas podrían haber sido diferentes, en todo caso, si el nacionalismo vasco y catalán (PNV y CiU, sobre todo, pero también ERC durante la presidencia de Rodríguez Zapatero) no hubieran tenido el papel decisivo que se deriva para ellos de nuestro peculiar sistema de partidos, pues, como es bien sabido, cuando la mayoría parlamentario-gubernamental no es absoluta, los gobiernos no han tenido otra alternativa en las Cortes Generales (sobre todo en donde resulta políticamente relevante, es decir, en el Congreso de los Diputados) que completarla con el apoyo de diputados de los partidos nacionalistas que acabo de citar, partidos que han venido aprovechando esa posición sistemática de privilegio para comportarse como auténticos grupos de presión, que se han dedicado a favorecer sin disimulo la imparable descentralización de los territorios que CiU y el PNV gobernaron durante la mayor parte del período autonómico. El resultado final de tal combinación de necesidades y posibilidades está bien a la vista y resulta bastante desalentador: el poder de esas Comunidades, y por emulación, de todas las demás - a través de aquella carrera de la liebre y la tortuga a la que se refirió un día el periodista y editor Javier Pradera—, no ha hecho otra cosa que aumentar, mientras, al mismo tiempo, y paradójicamente, se incrementaba también el desapego de los nacionalistas hacia un sistema autonómico que les ha venido garantizando niveles de autogobierno propios de un Estado federal pero que parece no haber servido para otra cosa que para ir acumulando los recursos de poder necesarios para preparar, «sin prisas pero sin pausas», el camino a la secesión.

\section{ENRIC FOSSAS ESPADALER}

El proceso constituyente emprendido de facto durante la transición se enfrentó de nuevo al "problema catalán», pendiente de resolución en nuestra historia constitucional, y que la dictadura franquista no logró eliminar a pesar de su política represiva. Como es sabido, los constituyentes se inspiraron en la experiencia de la Segunda República para llegar a ese compromiso constitucional «apócrifo» schmittiano, mediante el cual la decisión política sobre la organización territorial del Estado no se adoptó en la Constitución de 1978 y se 
remitió al momento estatutario posterior. Pero creo que también hubo un pacto implícito según el cual el Estado se comprometía a garantizar una autonomía política para Cataluña, y a cambio ésta renunciaba a la secesión. Los constituyentes acordaron la desconstitucionalización y el principio dispositivo, quedando buena parte del Título VIII como derecho constitucional transitorio: esas son las singularidades de lo que hemos llamado Estado autonómico. En este sentido, podría decirse que ese Título, junto al Preliminar, ha sido un instrumento integrador por cuanto permitió la recuperación de la autonomía que Cataluña perdió en 1939: su reconocimiento como «nacionalidad», y su conversión en una Comunidad Autónoma mediante el Estatuto de Autonomía de 1979, que tiene un carácter innegable de pacto. Una integración, sin embargo, subconstitucional: ni el reconocimiento ni el poder de Cataluña se encuentran en el texto constitucional sino en la llamada «constitución territorial», que tiene un carácter abierto y evolutivo mediante su interpretación por el TC, su concreción por parte del legislador estatal, y la posibilidad de la reforma estatutaria. De ahí que a mi juicio fueran más decisivos los factores de integración política: el restablecimiento de la Generalitat provisional en 1977, la participación de los representantes catalanes en los trabajos constituyentes, y la implicación de las fuerzas políticas catalanistas en la gobernabilidad de la España democrática. En cualquier caso, el sistema permitió durante 30 años el desarrollo del autogobierno catalán desde el punto de vista político, identitario, competencial, institucional y financiero, de tal modo que Cataluña ha vivido bajo la Constitución de 1978 el periodo más largo de su historia disfrutando de autonomía política. ¿Hasta qué punto esta acumulación de poder ha servido para plantear después la secesión como objetivo político? Esta es una cuestión cuya respuesta requeriría rigurosos análisis desde diversas ópticas, no siendo seguramente la jurídica la más importante. Los estudiosos de los nacionalismos han debatido si la satisfacción de sus demandas políticas facilita su integración, o por el contrario, impulsa nuevas demandas hasta el objetivo final que es siempre la independencia. En el caso de Cataluña, se ha sostenido que durante el largo periodo de hegemonía del llamado «nacionalismo moderado», éste llevó a cabo una persistente acción de nation building que, mediante el domino de importantes resortes de poder, llegó a todos los ámbitos de la sociedad, y asentó progresivamente la idea de que Cataluña ya funcionaba «como si fuera un Estado» al margen de España. Esa acción «nacionalizadora» del gobierno autonómico catalán ha sido con toda probabilidad un factor importante para la creación de un estado de opinión favorable a la independencia, pero de nuevo habría que analizar la incidencia de otros factores que han llevado al rápido crecimiento del sentimiento independentista en una parte de la sociedad catalana durante la última década, y su expresión política. Me refiero a la grave y larga crisis económica e institucional que atraviesa España, y a la desastrosa actuación de su Gobierno en relación con Cataluña en los últimos años. Finalmente, los expertos en demoscopia han señalado algunos datos importantes a 
tener en cuenta para comprender la realidad: el primero, que pone de manifiesto las mayorías asimétricas que se dan en Cataluña y España en relación con la descentralización y las preferencias invertidas de sus ciudadanos respecto del Estado autonómico; y el segundo, que advierte de la dificultad de contabilizar con precisión los independentistas «incondicionales» dentro de Cataluña, así como las preferencias de los no independentistas. Todo ello demuestra la complejidad del "problema catalán» tal como se presenta en la actualidad, y la necesidad de tenerla en cuenta tanto a la hora de realizar diagnósticos como de proponer soluciones políticas, y también constitucionales.

\section{TERESA FREIXES SANJUAN}

Detectar qué papel ha podido desempeñar el Título VIII de la Constitución en la relación de Cataluña con el resto de España necesita retrotraernos al momento de su elaboración, en los acuerdos habidos en la ponencia que redactó el anteproyecto de Constitución. Ya en aquellos momentos se barajaron varias opciones y el hecho de que formaran parte de la ponencia Miguel Roca y Jordi Solé Tura fue decisivo al respecto. Lo fue porque la inclusión de Roca supuso el anclaje de los nacionalismos moderados del País Vasco y de Cataluña ya que ello se pudo hacer gracias a que el PSOE cedió uno de los dos puestos que se habían fijado para este partido con la finalidad de que tales tendencias pudieran formar parte del consenso constitucional. También ayudó el hecho de que el ponente comunista, Jordi Solé, fuera también catalán y coadyuvara en tal sentido. En 1978 se pudo llegar hasta donde se pudo llegar, de modo que no se cerró el modelo autonómico y ello constituyó, de origen, una ventaja. Nos habíamos creído que el consenso les había alcanzado.

Sin embargo, con el transcurso de los años, el carácter abierto de este Título VIII fue aprovechado por un nacionalismo que se iba radicalizando, no en sus manifestaciones externas al principio, sino en ir conformando la opinión de que era necesario aprovechar todo lo que de él pudiera obtenerse mientras no fuera posible otra opción más contundente. No podemos olvidar que el independentismo ha sido una constante en la historia de Cataluña y que ha tenido más o menos adeptos en concordancia con la situación global del sistema político de cada momento.

La apertura del Título VIII ha sido constantemente utilizada por el nacionalismo catalán para aumentar las competencias inicialmente adquiridas al redactarse el primer Estatuto de Autonomía, el de 1979, mediante la transferencia de competencias a través del artículo 150.2 CE, especialmente en los períodos en los que no ha existido mayoría absoluta de ningún partido en el Congreso de los Diputados. Facilitar «la gobernabilidad» a cambio de concesiones competenciales por parte del Estado, mediante la llamada política «de peix al cobe» Epescado en la cesta, equivalente al castellano refrán del «pájaro en mano»] ha sido una constante. 
Visto con retrospectiva, da toda la impresión de que el nacionalismo catalán ha ido escondiendo la finalidad de la secesión mientras la ha estado preparando concienzudamente a lo largo de tres décadas. No se puede entender, sin tener esto presente, la política educativa de la Generalitat, dirigida a la creación de una conciencia nacional catalana aún a costa del falseamiento de la historia y del empobrecimiento cultural de la población escolar; tampoco es ajeno a este planteamiento la política de comunicación, con la subvención descarada de los medios, escritos y audiovisuales, dirigida a la formación de un concepto cultural catalán totalmente ajeno de sus orígenes. $\mathrm{O}$, por poner otro ejemplo, el saqueamiento impune de las arcas públicas o el cobro de porcentajes en la contratación de servicios o la realización de obras públicas, con desviaciones de fondos que, en vez de dedicarse a las finalidades propias de las competencias autonómicas, han sido utilizados para la creación de facto de nuevas competencias, fuera del marco constitucional cuando no claramente anticonstitucionales, durante los últimos años.

$\mathrm{Si}$, en los primeros años de la democracia, la apertura del Título VIII, que había creado un modelo autonómico dinámico, con posibilidad de adaptarse a los tiempos, ha podido ser considerado como algo positivo, la evolución del sistema autonómico, sobre todo en los últimos años, ha ido derivando en una clara regresión, en cuanto a la cohesión política, económica y social, del modelo instaurado con la Constitución de 1978.

\section{JAVIER GARCÍA FERNÁNDEZ}

El modelo de descentralización que se impulsa en España desde 1977 estaba orientado, principalmente, a satisfacer las reivindicaciones autonomistas que habían impulsado los partidos y las élites empresariales y culturales de Cataluña y del País Vasco. Al igual que en la Segunda República, desde las elecciones de 15 de junio de 1977, el Gobierno del Presidente Suárez y la mayoría de los partidos representados en las Cortes Constituyentes estaban comprometidos a ofrecer un modelo de descentralización para Cataluña y para el País Vasco. Desde ese punto de vista, el Título VIII tenía una vocación fuertemente integradora de Cataluña (y del País Vasco) aun cuando, como ha mostrado Francesc de Carreras, en Cataluña hubiera independentistas de Convergència Democràtica que estaban disfrazados de autonomistas.

Todo proceso de descentralización atribuye poder a un territorio que hasta entonces no lo tenía. Desde ese punto de vista, con un modelo centralizador como el que había en la dictadura franquista, no hubiéramos podido ver al Parlamento catalán adoptar acuerdos secesionistas ni tampoco a la Presidente del Parlamento dar gritos subversivos. Pero esos son los riesgos que tiene la democracia, que un grupo o un partido antisistema se ampare en las garantías y en los procedimientos democráticos para combatir la democracia. Aun con esos riesgos, en un país de la 
extensión y de la variedad culturales de España era casi necesario establecer un modelo descentralizador, y no sólo para Cataluña.

\section{JOSÉ ANTONIO MONTILLA MARTOS}

El Título VIII no ha sido integrador de Cataluña ni de ningún otro territorio porque no había sido diseñado para ello. Planteaba un proceso de descentralización a partir de un Estado unitario y se ocupaba, fundamentalmente, de regular el proceso de formación del Estado autonómico, con la creación de CCAA y la asunción de facultades competenciales sobre distintas materias por éstas a través de traspasos negociados bilateralmente. El modelo no era integrador, ni por su estructura ni por su contenido. En cuanto a su estructura responde a un federalismo de devolución, no de integración, como no podía ser de otra forma pues partíamos de un preexistente Estado unitario que iba a ser reformado. Sabemos que el problema de los federalismos de devolución es que suponen un proceso de vaciamiento paulatino de la federación, el Estado en nuestro caso, sin que resulte definido el límite del proceso descentralizador. En cuanto al contenido, la Constitución no prevé mecanismos de integración como pueden ser procedimientos e instituciones que faciliten el acuerdo en el ejercicio de las competencias compartidas o el diálogo entre las Comunidades y de éstas con el Estado. Lo sorprendente no es que la Constitución de 1978 tuviera esas carencias pues respondía a unas necesidades precisas y el consenso imponía imprecisión y ambigüedad. El problema es que desde 1978 no se haya modificado la estructura constitucional para reforzar ese contenido integrador. La consecuencia es que se ha desarrollado un federalismo yuxtapuesto y de conflicto, en el que Estado y CCAA han actuado de espaldas en el ejercicio de lo que consideraban su espacio de actuación competencial respectivo, sin que existan procedimientos e instituciones que habiliten el diálogo y, con ello, la integración, sino intentando expandir lo más posible el espacio propio. Las CCAA, especialmente las que tienen un fuerte sentimiento identitario, a través de reformas estatutarias o la solicitud de transferencias; el Estado a través de una concepción material de las bases que ha permitido su expansión casi ilimitada o el control desde arriba de los foros de encuentro y diálogo, desde las conferencias sectoriales o la conferencia de presidentes hasta el Consejo de Política Fiscal y financiera. El federalismo de conflicto en que se ha convertido el Estado autonómico es el resultado de ese proceso. En él, el órgano de resolución de conflictos, el Tribunal Constitucional, se hace omnipresente y termina convertido en un actor político más. Por ello, la crisis territorial actual no deriva de una hipotética «acumulación de poder» por las CCAA pues esa pretensión ha sido respondida con una expansión de los títulos del Estado que ha permitido a las CCAA la gestión pero ha limitado su capacidad para el diseño de políticas propias en sus ámbitos competenciales. El problema está en la ausencia de procedimientos e instituciones que impulsen y faciliten la integración. 


\section{MIGUEL SATRÚSTEGUI GIL-DELGADO}

Aunque ahora muchos temen que haya sido una oportunidad perdida, la Constitución de 1978 ofreció la ocasión y el contexto para una mejor integración de Cataluña en España, al aunar la restauración de la democracia con la apertura de un proceso de profunda descentralización del Estado. Y la opinión pública en Cataluña reconoció esa oportunidad, como lo demuestran las amplias mayorías con las que el cuerpo electoral catalán respaldó la Constitución de 1978 y el Estatuto de 1979. Además, la Constitución diseñó un modelo de régimen parlamentario con representación proporcional que facilitó que el nacionalismo catalán tuviera un rol importante en el sistema político español, porque los gobiernos en minoría en el Congreso de los Diputados dependieron de forma recurrente del apoyo de $\mathrm{CiU}$, a efectos de completar la mayoría parlamentaria. Lo que otorgaba a $\mathrm{CiU}$ un notable poder negociador.

El carácter abierto del Título VIII de la Constitución y la amplitud con que acogió el llamado «principio dispositivo» fueron planteamientos útiles para conseguir un acuerdo amplio entre las fuerzas políticas que protagonizaron el proceso constituyente, aunque fuera un acuerdo incompleto que se refería al proceso de descentralización más que a sus resultados. Pero ese planteamiento abierto de la Constitución, en especial en aspectos relativos a las competencias autonómicas, ha contribuido también a una conflictividad bastante intensa entre el Estado y las comunidades autónomas, sobre todo con aquellas, como la catalana, gobernadas generalmente por fuerzas nacionalistas. $\mathrm{Y}$ aunque la jurisprudencia del Tribunal Constitucional ha procurado precisar las ambigüedades del Título VIII —en muchos aspectos de manera favorable y protectora de la autonomía - no ha impedido que persista un notable grado de confusión en la distribución de competencias ni ha podido suplir la falta de un consenso claro sobre la estructura territorial del Estado.

Pero no creo que haya una relación causal entre el problema competencial y el secesionismo. Parece más plausible interpretar que el espectacular crecimiento de la opción secesionista obedece a factores y acontecimientos más marcadamente políticos. El nacionalismo moderado catalán que apoyó la Constitución ha acumulado, a través de la Generalitat, un gran poder político que ha utilizado para modernizar Cataluña, pero también para una estrategia general de potenciación de la identidad nacional catalana a costa de la española. Esa estrategia ha creado un ambiente de hegemonía nacionalista en la sociedad catalana y ha permitido atraer a posiciones nacionalistas a partidos que inicialmente no procedían de esa matriz cultural, hasta el punto de que en 2005 y con un acuerdo bastante transversal de las fuerzas políticas catalanas, se intentó reformular la autonomía sobre bases más ambiciosas y más explícitamente nacionalistas. La desafección provocada por el desenlace de ese intento, que ha sido percibido como un fracaso, y también por las políticas de austeridad puestas en marcha por los gobiernos central y autonómico para combatir la prolongada crisis económica, está en el origen de la 
conversión al independentismo de amplias capas de la sociedad catalana, que han creído descubrir nuevas justificaciones políticas y económicas para la secesión. Pero no parece que el nacionalismo moderado haya liderado ese movimiento, más bien dio la impresión de adherirse al mismo para no ser desbordado. Con mayor razón, tampoco parece que la secesión fuera tácitamente desde el inicio de la Transición democrática el objetivo general del nacionalismo, aunque eso solo puede ser dilucidado por los historiadores, sin juzgar el pasado como mera antesala del presente ni sustituir el juicio histórico por las opiniones actuales de los actores políticos.

\section{EDUARDO VIRGALA FORURIA}

El problema de la integración territorial de Cataluña creo que está más en el entendimiento que se hizo del término «nacionalidad» que en el Título VIII, aunque algunos aspectos de su desarrollo tampoco han ayudado mucho en esa integración. A la hora de acomodar a Cataluña y a Euskadi en el Estado autonómico, un elemento que podía haber ayudado era la distinción del artículo 2 CE entre nacionalidades y regiones, entendiendo que la primera se refiriera exclusivamente a aquellas y a Galicia (por su mención indirecta en la Disposición Transitoria 2. ${ }^{a} \mathrm{CE}$ ), siendo las demás Comunidades Autónomas meras regiones. Un término el de nacionalidad que sin ser el de nación, imposible de utilizar por su vinculación a la soberanía detentada por la española, sí recogía los ecos de lo que fue el principio de las nacionalidades, como colectividades que pretenden un alto grado de autonomía sin que necesariamente eso se plasme en un Estado propio y, por otro lado, permitía diferenciar entre unas Comunidades y otras. En principio, políticamente tuvo la importancia de contentar al nacionalismo catalán asumiendo un papel legitimador de la Constitución, habiendo un cierto consenso implícito de que el término iría asociado a los territorios que más lejos habían llegado en materia autonómica en el periodo republicano, lo que se conectaría con la ya mencionada Disposición Transitoria 2. ${ }^{\mathrm{a}} \mathrm{CE}$.

El problema es que el artículo 2 CE no señala ningún criterio para definir a la nacionalidad ni para diferenciarla de la región, ni la asocia a la Disposición Transitoria $2 .{ }^{a} \mathrm{CE}$, y una cosa es la intencionalidad política y otra muy diferente la significación jurídica de un término. El artículo 2 no extrae consecuencias jurídicas de esa distinción ni la práctica constitucional posterior ha ido por ese camino, en lo que han confluido muchos factores para que el Estado autonómico tendiera hacia la uniformidad: reacción al golpe de estado del 23-F, pactos autonómicos, jurisprudencia constitucional en materia de legislación básica, etc. En definitiva, que no ha existido efecto jurídico alguno si una Comunidad se califica de nacionalidad o región. Ahora en 2015 no tendría sentido resucitar jurídicamente la distinción, ya que provocaría la negativa radical de las Comunidades Autónomas no laureadas con tal denominación, por lo que no parece una vía útil 
ya en la actualidad para establecer adicionales asimetrías jurídicas entre las Comunidades Autónomas.

En todo caso, la deriva secesionista en Cataluña tiene un componente político o, más bien, partidario, que es imposible de esquivar. Aunque durante muchos años CiU guardó en el congelador su lado más independentista y gobernó sin impugnar el marco constitucional, contribuyendo también a la estabilidad de los Gobiernos centrales, siempre estaba latente esa pulsión secesionista. A partir de la pérdida por ese partido del Gobierno catalán en 2003, del impacto que tuvo la STC 31/2010 y de las Diadas de 2012 y siguientes, esa pulsión secesionista se ha acentuado hasta llegar a la situación que hoy en día vivimos. A ello ha contribuido la actuación del Gobierno del PP que no ha ofrecido ninguna alternativa desde el marco constitucional y, por el contrario, ha impulsado una política de recentralización con la excusa de la crisis económica y ayudado por el enorme despilfarro de muchas Comunidades Autónomas en los últimos decenios. Esta recentralización se ha producido en muchas ocasiones mediante la declaración del «carácter básico» de una parte importante de los numerosos Decretos-Leyes de la legislatura actual (en sanidad, educación, funcionarios, pensiones, horarios comerciales, etc.). Creo que todos estos factores explican mejor la deriva independentista de Artur Mas y del nacionalismo catalán que la insatisfacción ante la interpretación que se ha realizado del Título VIII.

2. En su opinión, ¿qué ha podido significar en el proceso soberanista el Estatuto de Autonomía de Cataluña de 2006? ¿Y la STC 31/2010 que resolvió el recurso de inconstitucionalidad presentado desde la oposición?

\section{ENOCH ALBERTÍ ROVIRA}

Dicho en pocas palabras, creo que el Estatuto de 2006 significó el intento de actualizar el pacto autonómico para, al menos, las dos generaciones siguientes, y que la Sentencia 31/2010 supuso el fracaso de este intento, dejando la cuestión de la articulación entre Cataluña y España sin alternativas.

En efecto, el Estatuto de 2006, que fue el resultado de un largo, complejo y problemático proceso de negociación -internamente entre las fuerzas políticas catalanas, primero, y después entre éstas y las estatales-, y constituyó un intento de actualizar, treinta años después del primer Estatuto, el régimen de autogobierno de Cataluña, tanto para hacer frente a los problemas que se habían presentado a lo largo de estos años de desarrollo autonómico (relativos a la distribución de competencias, las relaciones intergubernamentales y, en general, la relación entre los poderes centrales y los territoriales, el régimen local, la financiación, ...), como para abordar situaciones nuevas no contempladas inicialmente (pe., la participación en asuntos europeos, que se habían ido resolviendo mediante fór- 
mulas con escasas garantías institucionales), al tiempo que se establecía un reconocimiento más claro, explícito y garantista de la propia identidad, especialmente en el ámbito lingüístico.

Sobre el Estatuto de 2006 cabe además añadir dos consideraciones generales: en primer lugar, la voluntad de mantenerse dentro del marco constitucional, tanto por lo que hace al procedimiento (respeto escrupuloso del procedimiento de reforma estatutaria previsto, incluyendo la aceptación de las modificaciones introducidas en el trámite de las Cortes Generales) como a los contenidos normativos (nueva regulación de algunas materias, introduciendo innovaciones respecto del Estatuto de 1979, que cabían dentro del marco general de la Constitución, aunque en algunos casos mediante una interpretación distinta de la dominante hasta el momento, pero no por ello menos plausible). Y, en segundo lugar, hay que tener en cuenta que la reforma estatutaria se planteó como una opción para actualizar el autogobierno y resolver los problemas planteados ante la imposibilidad, política, de reformar la Constitución. Ciertamente, habría sido conveniente que algunas de las materias abordadas en el nuevo Estatuto hubieran tenido un tratamiento constitucional previo. Pero ello no significa que, en términos estrictamente jurídico-constitucionales, no pudieran ser abordados en un Estatuto de Autonomía, dado el peculiar sistema español, en el que, dentro del bloque de la constitucionalidad que rige la organización territorial, éstos cumplen una función constitucional, concretando y complementando el marco general establecido en el texto de 1978. El alcance de esta función constitucional o, lo que es lo mismo, el papel de los Estatutos en el sistema autonómico español, es, desde luego, la gran cuestión constitucional que se plantea en el conflicto suscitado en relación con el Estatuto de Cataluña de 2006, y que el Tribunal Constitucional resuelve en sentido enormemente restrictivo y limitativo para los Estatutos, en general. Pero a mi juicio, no hay duda de que hubiera sido posible otra interpretación, que otorgara a los Estatutos un papel mucho más relevante, en línea, además, con el que habían jugado en la etapa fundacional del Estado autonómico y hasta este momento, y que el mismo Tribunal había reconocido, al menos en algunos aspectos, muy poco antes (STC 247/2007, sobre el Estatuto de la Comunidad Valenciana). El Tribunal, otra vez, como ha ocurrido en tantos otros casos en la construcción del Estado autonómico, y ante la ausencia de normas claras y específicas en la Constitución, ha suplido a los poderes políticos en la tarea de moldear el sistema territorial y fijar sus reglas de funcionamiento (pe., de manera destacada, en la definición de los tipos competenciales y, en especial, de las «bases» estatales). Pero en este caso, con el Estatuto de Cataluña de 2006, la actuación del Tribunal Constitucional interpretando la Constitución para fijar, ante el silencio o la ambigüedad de ésta, las reglas del Estado autonómico, no ha sido en lugar de, sino en contra de los poderes políticos ordinarios, pues éstos (Parlamento de Cataluña, Cortes Generales y electorado de Cataluña) habían ya manifestado expresamente su voluntad, interpretando políticamente la Constitución, en el Estatuto de 2006.

UNED. Teoría y Realidad Constitucional, núm. 37, 2016, pp. 13-98 
Este último es, a mi juicio, uno de los grandes problemas que presenta la STC 31/2010, sobre el Estatuto de Autonomía de Cataluña: el hecho de no sólo no mostrar la necesaria deferencia hacia el legislador, exigible en cualquier caso y más, si cabe, cuando se trata de una ley aprobada al mismo tiempo por las Cortes Generales y un Parlamento autonómico y ratificada después en referéndum, sino de ni siquiera dedicar una sola palabra a esta circunstancia especial, siendo además la primera vez que el Tribunal Constitucional conocía de una ley de estas características, ratificada en referéndum. Resulta realmente difícil entender porqué el hecho de controlar una ley ratificada en referéndum (después de haber sido aprobada mediante la confluencia de voluntades de dos Parlamentos) no merece ninguna consideración por parte del Tribunal Constitucional, y más aún siendo ésta la primera vez que ello ocurre.

Pero éste no es el único problema que presenta la STC 31/2010. La Sentencia, más allá de las declaraciones concretas de inconstitucionalidad y nulidad de determinados preceptos del Estatuto catalán (14 preceptos, sobre los 199 impugnados), a través de las numerosas declaraciones interpretativas que contiene (muchas de las cuales fueron llevadas al fallo de la sentencia), tiene un efecto general sobre el Estatuto de Cataluña y, más allá aún sobre el entero sistema autonómico, en la medida que reduce hasta la casi irrelevancia la función constitucional de los Estatutos de Autonomía y niega prácticamente cualquier posición especial de los mismos en el ordenamiento español, especialmente respecto de las leyes estatales, y singularmente las orgánicas. No se trata ahora de desarrollar estas ideas, que he tenido ocasión de exponer más detalladamente en otros trabajos, pero sí me gustaría indicar que la STC 31/2010 trata a los Estatutos como simples leyes orgánicas, tanto respecto de la Constitución (principio de jerarquía, a secas, sin ninguna referencia al carácter complementario y la función constitucional de los mismos que la STC 247/2007 sobre el Estatuto valenciano había enfatizado) como en relación al resto de leyes estatales, ordinarias y orgánicas (que se rige, dice la Sentencia, simplemente por un principio de competencia que deriva de la reserva material que la Constitución establece a favor de los Estatutos). El Estatuto de Autonomía, así, no tiene ninguna capacidad vinculante del Estado, olvidando no sólo la función constitucional que cumple sino, simplemente, que se trata de una ley estatal. Ley estatal, además, que emana de las Cortes Generales después de un proceso legislativo muy especial y que se dota, por mandato constitucional directo y expreso, de una especial rigidez, que le debería conferir una posición también especial en el ordenamiento, como ya había dicho el propio Tribunal en ocasiones anteriores. De este modo, los Estatutos - en general y no solo el catalán—quedan enormemente devaluados, y, con ello, queda afectado el entero sistema autonómico español, que pierde una de sus piezas esenciales. Con ello, se abrieron incógnitas muy serias sobre el futuro del Estado autonómico y su capacidad para seguir ejerciendo la función de integración que corresponde a la Constitución en este ámbito, y, particularmente en relación con Cataluña, el futuro del autogobierno quedó sin alternativa. Creo, en efecto, que la actual situa- 
ción que vive Cataluña arranca específicamente de esta devaluación general del Estatuto de 2006, que dejó sin capacidad de evolución al sistema constitucional de autogobierno en Cataluña, sin alternativa para la resolución de los numerosos problemas y déficits que arrastraba. No se trata de discutir sobre la legitimidad de la interpretación que sostiene el Tribunal Constitucional en su Sentencia sobre el Estatuto catalán, pero creo que era también perfectamente posible y plausible otra interpretación, mucho más respetuosa con éste. Al final, el Tribunal opta por una interpretación del sistema autonómico muy restrictiva, con el efecto de excluir del marco constitucional unas opciones en las que se movían una parte muy significativa, incluso mayoritaria, de las fuerzas políticas de Cataluña. La conflictiva situación actual deriva precisamente, en mi opinión, de tal exclusión.

\section{ROBERTO BLANCO VALDÉS}

El Estatuto de 2006 tal y como salió del parlamento catalán, y antes de la modificación del texto llevada a cabo en el Congreso, era un proyecto legal de clara matriz confederal, que no se correspondía en absoluto con la naturaleza de las normas sub estatales propias de los Estados federales. En él se expresaba hasta tal punto un modelo de organización territorial que era completamente incompatible con el principio de unidad previsto en el artículo $2{ }^{\circ}$ de la Constitución, que resulta incomprensible que fuera apoyado no sólo por los partidos nacionalistas sino también por la izquierda no nacionalista y de forma muy sobresaliente por el PSC, que mantuvo en todo el proceso histórico que condujo al momento de desafío al orden constitucional en el que estamos una postura errática, con cambios constantes de posición y que contribuyó, por ello, en no pequeña medi$\mathrm{da}$, a facilitar la deriva soberanista de las fuerzas nacionalistas: por ejemplo, apoyando con toda claridad inicialmente la celebración de un referéndum de autodeterminación. El proyecto de Estatuto supuso el primer paso, pues, en el camino hacía eso que se dado en llamar la «desconexión» de Cataluña con España, es decir, con el resto de España, de la que Cataluña forma parte desde tiempo inmemorial. Modificado profundamente en el Congreso, el texto fue sometido a referéndum de los electores catalanes, y los partidos que lo habían apoyado en el parlamento catalán lo apoyaron luego en esa consulta popular, con la única excepción de ERC. Resulta curioso por ello que la misma CiU que no tuvo inconveniente en pedir el voto favorable a un Estatuto que había salido del Congreso con muchos y muy profundos cambios, pusiera luego el grito en el cielo por la sentencia del TCE que, en realidad, anulaba, sólo parcialmente, 14 preceptos de un Estatuto extensísimo de 223 artículos, además de sus disposiciones adicionales, transitorias y finales. Es verdad que previsiones que afectaban a 27 artículos más (que se llevaban al fallo) y a otros 49 (que no aparecían en el fallo) fueron sujetas a interpretación conforme, pero, como era previsible, la eficacia de tales interpretaciones ha resultado o nula o muy escasa. Baste mencionar a ese respecto las re- 
lacionadas con la significación de la cooficialidad lingüística y con el impacto que tal significación debería tener - y no ha tenido — en la enseñanza.

Por ello resulta más que sorprendente como la tesis política de que la sentencia 31/2010 del TCE fue el elemento decisivo de la ruptura entre España y Cataluña (es decir, entre España y el nacionalismo catalán, que representa sólo a un parte, y no la mayor de Cataluña) pudo hacer tan pronta fortuna. En refutación de tal tesis, bien sé que de escasa utilidad contra una falsedad histórica que ha adquirido una naturaleza similar a la de un prejuicio popular, puede alegarse el hecho incontestable de que la modificación que el proyecto de Estatuto catalán experimento tras su paso por las Cortes fue mucho mayor que el derivado de la sentencia del TCE, sin que ello impidiera a CiU y al PSC de Montilla, que luego pusieron al alimón el grito en el cielo por la sentencia, pedir el sí para aquel en el referéndum. Pero es que además, la misma CiU que tras la sentencia del Estatuto de junio de 2010 pasó a gobernar en diciembre de ese año en Cataluña pudo hacerlo inicialmente, y sin que ello le produjese ningún tipo de conflicto, contando con el apoyo o la abstención del mismo Partido Popular que era, supuestamente, el responsable del gran atentado contra Cataluña que había supuesto una sentencia dictada como consecuencia del recurso de inconstitucionalidad que el citado partido había presentado. Y es que una cosa son los hechos, y otra muy distinta la falsa realidad que se ha construido manipulándolos sin el más mínimo recato.

\section{ENRIC FOSSAS ESPADALER}

El Estatuto de 2006 se vio precedido por la llamada «Declaración de Barcelona», firmada en 1998 por las fuerzas nacionalistas de Cataluña, el País Vasco y Galicia; y por la legislatura de las Cortes 2000-2004, con mayoría absoluta del PP, en la que el Gobierno presidido por Aznar se mostró muy beligerante con los nacionalismos, especialmente con el vasco, tras el «Acuerdo de Lizarra» y la ruptura de la tregua por parte de ETA en 1999. En ese contexto político se elaboró el fallido Plan Ibarretxe en 2004, mientras en Cataluña los partidos surgidos de las elecciones de 2003 (excepto el PP), proponían en sus respectivos programas la reforma del Estatuto de 1979 como vía para la mejora del autogobierno. La tramitación parlamentaria duró casi dos años, en los que el debate estatutario acaparó la vida política catalana pero también la española. La elaboración de la propuesta en el Parlament se llevó a cabo bajo lo que se denominó «el mito del Estatuto-Constitución», y la reforma se entendió en realidad como la refundación de la comunidad política a partir de una cierta idea de autodeterminación. De ahí que el texto surgido del Parlament en septiembre de 2005 fuera de difícil encaje constitucional e inasumible políticamente, y por ello se introdujeron numerosas e importantes modificaciones hasta su aprobación por las Cortes en 2006, siendo después refrendado por el $73,2 \%$ de los ciudadanos de Cataluña con una participación de solo el 48,9\%. La reforma estatutaria generó numerosas tensiones entre 
las fuerzas políticas de Cataluña (ERC finalmente no apoyó el texto), y de éstas con el Gobierno central; y desató una oposición frontal del PP, que votó y realizó una campaña en contra del nuevo Estatuto. Todo ello puede ayudar a entender el significado que para el proceso soberanista tuvo el Estatuto de 2006: fue una propuesta de pacto político para dotar a Cataluña de un nuevo estatus constitucional y reformar el sistema sin reformar la Constitución. La operación generó tensiones y expectativas finalmente frustradas, debido a los errores técnicos y políticos cometidos en Cataluña y a la actitud de las fuerzas políticas estatales.

Si la desafortunada operación estatutaria pudo ser un factor causal del proceso, la impugnación masiva del nuevo Estatuto por parte del PP (que no impugnó otras reformas estatutarias de contenido similar), y su resolución mediante la STC $31 / 2010$ creo que puede considerarse un claro factor desencadenante del mismo. Por un lado, las vicisitudes políticas y jurídicas acaecidas durante los cuatro años de tramitación y deliberación en el Tribunal Constitucional hicieron aflorar las peores pulsiones todavía presentes en la precaria cultura constitucional española, y trasladaron a esa institución las batallas políticas surgidas con la reforma, lo cual redundó en una irreparable pérdida de su autoridad incluso antes de dictar la Sentencia. Ésta, por otro lado, adoptada con cinco votos particulares, si bien declaró la nulidad de solo 14 de los 144 artículos impugnados, llevó a cabo una utilización sui generis de la técnica de la interpretación conforme de muchos preceptos estatutarios, que quedaron «desactivados» con base en una determinada concepción de la naturaleza, contenido y función de la norma estatutaria que la convierte en irrelevante. La Sentencia, con un tono inadecuado y excesivamente dogmático, también reinterpretó las materias sensibles, como la definición «nacional» de Cataluña y el régimen jurídico de la lengua catalana. Con todo ello se cerraba el paso a los principales objetivos políticos y jurídicos de la reforma propuesta, pero también a una futura evolución del sistema basado en los Estatutos. Más allá de estas consecuencias jurídicas, la Sentencia desató un fuerte malestar en Cataluña: por su larga y lamentable tramitación en el Tribunal; por considerar que aquél carecía de legitimidad para juzgar una norma aprobada por dos Parlamentos y refrendada por los ciudadanos de Cataluña; y por entender que constituía un rechazo contundente a una propuesta de pacto «constitucional» realizada desde Cataluña, que contenía unas aspiraciones políticas ya reducidas en la tramitación parlamentaria. La culminación y máxima expresión del rechazo a la Sentencia se visualizó en la masiva manifestación (alrededor de un millón de personas) que bajo el lema «Somos una Nación. Nosotros decidimos» tuvo lugar en Barcelona el 10 de julio de 2010 con el apoyo de la mayoría de las fuerzas políticas catalanas, los sindicatos y numerosas entidades. Creo que es un hecho insólito en Europa que se lleve a cabo una manifestación de ese carácter contra una Sentencia de un Tribunal Constitucional. En las elecciones catalanas celebradas el 28 de noviembre de ese año, CiU recuperó la mayoría (62 diputados) y Artur Mas fue investido Presidente de la Generalitat. Transcurrieron dos años, en los que se reclamó un pacto fiscal, hasta la decisiva manifestación del 11 de septiembre de 
2012, cuyo lema fue «Cataluña, nuevo Estado de Europa», y que puede considerarse el punto de arranque del proceso soberanista.

\section{TERESA FREIXES SANJUAN}

La aprobación del Estatuto de Autonomía de Cataluña de 2006, siguiendo el procedimiento constitucionalmente establecido y de acuerdo con las previsiones de la Ley Orgánica del Tribunal Constitucional y del entonces vigente Estatuto de Autonomía de 1979, como no podía ser de otra manera, fue entendida por buena parte de los actores políticos del momento como el instrumento con el que se podría ir más allá del marco constitucional porque ellos así lo habían decidido (no cuajó el intento de reforma, limitada a cuatro puntos, de la Constitución que había sido incluida en el programa electoral del Partido Socialista en 2004). El Estatut resultante fue aprobado por el Parlament de Cataluña, con suficiente mayoría pero con insuficiente consenso, porque no se quiso o no se pudo llegar a un acuerdo con el Partido Popular, actuando bajo el lema acuñado por el entonces President de la Generalitat y el entonces Presidente del Gobierno de España, ambos socialistas, consistente en que «Madrid aceptaría lo que le llegara desde el Parlament de Cataluña».

Dado que los Estatutos de Autonomía deben ser aprobados en las Cortes Generales mediante ley orgánica, el texto que llegó «a Madrid» fue discutido, enmendado y modificado en buena parte de su articulado en el parlamento español, mediando además un rocambolesco «pacto nocturno» entre el Presidente del Gobierno y el líder de Convergencia Democrática, actual President en funciones de la Generalitat, entonces en la oposición y a espaldas del Gobierno catalán del momento.

Ello fue debido a dos importantes circunstancias. Por una parte, a que, además del Partido Popular, buena parte del Partido Socialista tampoco veía claro que un Estatuto de Autonomía pudiera modificar, de facto, el marco constitucional. Por otra parte, a que Convergencia quería tomar protagonismo y desplazar de la negociación al Gobierno catalán, llamado «el tripartito» porque se había formado, con el Pacte del Tinell, mediante una alianza entre el Partido Socialista de Cataluña, Esquerra Republicana e Iniciativa por Cataluña/Izquierda Unida. Entre estos tres partidos se podía obtener la mayoría necesaria para formar gobierno, pero ninguno de ellos, por separado, había superado a Convergencia, en votos o en escaños, en las elecciones autonómicas. Es bueno recordarlo para entender lo que está pasando en Cataluña en este momento.

Una vez que fue aprobado por ley orgánica, el Estatuto, con el contenido acordado en las Cortes, pasó a referéndum del pueblo catalán, referéndum vinculante por expresa disposición constitucional y en el que la participación no llegó a la mitad del censo. Obtuvo casi un $74 \%$ de votos a favor, más del $20 \%$ de votos en contra y un $5 \%$ de voto en blanco. Haciendo bien las cuentas, resulta que el 
Estatut fue respaldado por alrededor del $36 \%$ de la población con derecho a voto. Sólo la clase política, y no toda, estaba enrocada en conseguir el nuevo Estatut. A buena parte de la población de Cataluña, por no decir a la mayoría, el Estatut le traía al pairo.

Y aquí es donde aparece el chivo expiatorio, es decir, el Tribunal Constitucional, puesto que el Estatut refrendado fue recurrido ante este Tribunal, no sólo por el Partido Popular, sino, entre otros, porque hubo hasta siete recursos, también por el Defensor del Pueblo. Ya en ese momento se comenzó a decir, desde los partidos políticos del ámbito catalán, que acudir al Tribunal Constitucional provocaría la «desafección de los catalanes» hacia España, porque el Tribunal no podía (sic.), decían, controlar la constitucionalidad de un Estatuto aprobado en referéndum popular.

Ello fue jurídicamente posible porque el recurso previo de inconstitucionalidad sobre leyes orgánicas (los Estatutos de Autonomía entre ellas), había sido suprimido, a pesar de las opiniones contrarias que muchos expresamos en relación con lo que podía pasar con los Estatutos, con los votos del Partido Socialista (que incluyeron los del Partido Socialista de Cataluña), del Centro Democrático y Social y también con los de la Minoría Catalana. De este modo, sin tacha legal alguna, se presentó recurso contra el Estatuto de 2006 y el Tribunal Constitucional resolvió el tema declarando contrarios a la Constitución algunos artículos y realizando una sentencia interpretativa sobre el resto.

El Tribunal Constitucional ha sido una especie de chivo expiatorio del mal hacer de nuestros políticos, aunque no se puede menos que constatar que no es precisamente suya, es decir, del Tribunal, la responsabilidad de lo que sucedió con el Estatut, puesto que el procedimiento de control de constitucionalidad que se utilizó estaba totalmente ajustado a Derecho. Y que resulta bastante alucinante que, hoy en día, precisamente algunos de los que colaboraron en la desaparición del recurso previo traigan de nuevo a colación que la «desafección de los catalanes» hacia España tiene su origen en que el Tribunal Constitucional dictó ilegítimamente la sentencia sobre el Estatut porque éste había sido aprobado por el pueblo catalán en referéndum.

Afortunadamente, tal situación no va a poder ser repetida, puesto que se ha vuelto a instaurar el recurso previo de inconstitucionalidad para controlar los Estatutos de Autonomía, mediante una nueva reforma de la Ley Orgánica del Tribunal Constitucional y, en su caso, el referéndum se haría después de que el Tribunal hubiera dictaminado la constitucionalidad del Estatuto.

Pero sí que podemos estar otra vez, si es que se realizara una reforma de la Constitución que fuera seguida de un nuevo Estatuto de Autonomía, ante el hecho de que el Estatuto no fuera, como en 1979, una norma consensuada, puesto que parece que no aprendemos de la historia. Las normas institucionales básicas, las Constituciones, los Estatutos de Autonomía, no pueden ser adoptadas ni reformadas sin el consenso necesario. Si sólo se obedece a lo que podríamos denominar «la regla de la mayoría», aplicada sin mayor argumento que la fuerza de 
los votos, podríamos reproducir la situación en que, retorciendo el funcionamiento de las instituciones, se facilitó, en el período de entreguerras, el acceso al poder de las más tiránicas formas de opresión y de humillación del individuo, de exclusión social y de exterminio del disidente.

\section{JAVIER GARCÍA FERNÁNDEZ}

El Estatuto de Autonomía es producto de la frivolidad de unos y de la desidia de otros. Cuando se inició la redacción del proyecto de Estatuto la sociedad catalana no exigía un nuevo Estatuto pero Maragall y el PSC, para competir con $\mathrm{CiU}$, lo puso en marcha y además lo puso en manos de un independentista agazapado sin hacer un seguimiento de lo que se estaba redactando en el Instituto de Estudios Autonómicos. El Gobierno catalán de Maragall y el PSC se desentendieron de lo que es estaba redactando y tampoco pretendieron cambiar luego un proyecto que era ya inconstitucional. Tampoco hubo el menor seguimiento por parte del Gobierno de la Nación ni por parte del P.S.O.E. y éste sólo reaccionó cuando era público el proyecto y toda rectificación suponía ya un enfrentamiento con el PSC.

A partir de un procedimiento de elaboración estatutaria tan inmeditado (de quienes tenían que meditar las consecuencias de lo que estaba haciendo), el nuevo Estatuto tenía que chocar mucho o poco con la Constitución (yo mismo algunos puntos de fricción señalé en «El proyecto de reforma del Estatuto de Cataluña y la Constitución», Temas para el debate, n. ${ }^{\circ} 132$, noviembre 2005, pp. 8-9). Y al chocar, el PSC y el Gobierno que presidía Montilla tendrían que haber meditado a medio y a largo plazo y no competir como CiU a ver quién vertía más lágrimas y quién movilizaba más gente contra Madrid. Por eso la especies que lanzó Montilla (todo un ex-Ministro de España) contra el Tribunal Constitucional y el encabezar una manifestación contra la Sentencia que resolvió el recurso de inconstitucionalidad es un baldón que llevará el PSC y Montilla toda su existencia y, en términos políticos, uno de las factores que más fortaleció el independentismo. A partir de la actitud del PSC los independentistas antiguos y los que se estaban preparando para serlo se fortalecieron y se inventaron, con grandes medios de agitación y propaganda, un nuevo 1714 que en materia de inventar historia los independentistas son maestros. La Sentencia constitucional 31/2010 fue para el independentismo como la voladura del crucero Maine en 1898, el pretexto para iniciar una guerra que previamente ya se había preparado.

\section{JOSÉ ANTONIO MONTILLA MARTOS}

El Estatuto de Cataluña de 2006 era una suerte de propuesta de pacto lanzada desde Cataluña ante una sensación de insatisfacción autonómica que se expo- 
nía en el Informe sobre la Reforma del Estatuto elaborado por el Institut d'Estudis Autonomics, dependiente del Gobierno de Cataluña, en noviembre de 2003. Y, ciertamente, tras introducir numerosas enmiendas en el texto del Estatuto, fue aceptado por la mayoría absoluta de las Cortes Generales, aunque no completamente consensuado pues tuvo el rechazo del PP y de ERC, que había apoyado el texto aprobado en el Parlamento autonómico. A mi juicio, significaba un adecuado punto de inicio para una nueva etapa del Estado autonómico. Creaba un modelo de Estatuto de segunda generación que podía ser emulado en otros territorios, adaptándolo a los intereses específicos, como hizo de forma inmediata Andalucía. El procedimiento no era el idóneo en términos políticos pues obligaba al encaje no siempre fácil de 17 piezas en un ordenamiento constitucional único y coherente, por más que cumpliera con las prescripciones procedimentales previstas en la Constitución. Por ello, parecía inevitable que ese proceso de reformas estatutarias culminara con una reforma constitucional. Obviamente, debía haberse realizado antes pero ante la inacción del poder de reforma constitucional, las propias CCAA, específicamente Cataluña, tomaron la iniciativa y, por tanto, la reforma constitucional quedaba pospuesta a las reformas estatutarias. Sin embargo, el virulento conflicto político desatado en torno al Estatuto de Cataluña convirtió lo que era un instrumento para evitar el conflicto territorial y favorecer la conllevanza en un arma arrojadiza que agravó la crisis territorial. La STC 31/2010 fue el punto culminante pues tras unos antecedentes poco edificantes fue interpretada por algunos sectores impulsores de la reforma estatutaria como la demostración de que el pacto era imposible y sólo cabía apostar por la secesión. Con ello, por la mera suma aritmética de los independentistas tradicionales y estos nuevos independentistas surgidos del fracaso del proceso estatutario los partidarios de la independencia han llegado a ser prácticamente la mitad de la ciudadanía de Cataluña, lo que implica un problema político de primera magnitud.

A mi juicio, la sobreactuación de unos y otros nos ha llevado a la situación actual. La presión sobre el Tribunal fue excesiva; el Tribunal podía haber sido más prudente en su sentencia, como luego lo ha sido en la STC 42/2014, y la reacción a la sentencia en Cataluña fue exagerada. Si analizamos fríamente la STC 31/2010, algo más fácil a medida que nos alejamos temporalmente de ella, podemos comprobar que en la mayoría de los supuestos el Tribunal Constitucional no ha rechazado los contenidos estatutarios sino su inclusión en una fuente con eficacia territorial limitada como es el Estatuto de Autonomía en cuanto son aspectos que afectan a otros territorios y al Estado en su conjunto. Por tanto, resulta plenamente posible, a mi juicio, que una reforma constitucional incorpore los contenidos más novedosos incluidos en el Estatuto de Cataluña en relación a la definición de las categorías competenciales, la participación de las Comunidades en las decisiones del Estado que les afectan o los principios que deben regir el modelo de financiación autonómica. Esta es la forma de intentar reconducir la situación a través de un pacto federal que utilice como base los contenidos estatutarios para trasladarlos a la Constitución. 


\section{MIGUEL SATRÚSTEGUI GIL-DELGADO}

Después de un cuarto de siglo de ejercicio continuado de la autonomía catalana, no exento de conflictos, el Estatuto de 2006 representó un intento audaz de conseguir para Cataluña una posición especial en España, de maximizar su autonomía, de singularizarla respecto de las demás comunidades autónomas y de blindarla frente injerencias centralizadoras.

El nuevo Estatuto fue aprobado, en el Parlamento de Cataluña y en Congreso de los Diputados con el apoyo del nacionalismo moderado y del Partido Socialista, entre otras fuerzas políticas, pero prescindiendo del que era entonces principal partido de la oposición en España. Eso fue desde luego una imprudencia política, como lo confirmó la campaña contra el Estatuto que promovió el Partido Popular y la agresividad con la que este planteó la impugnación del Estatuto ante el Tribunal Constitucional, llegando incluso a la recusación de algunos de sus magistrados (que en un caso prosperó sin motivos suficientemente justificados).

Pero lo cierto es que el recurso de inconstitucionalidad, por muy inoportuno que fuera, tenía fundamento porque el nuevo Estatuto pretendía una cierta equiparación entre la norma estatutaria y la constitucional (por ejemplo, al redefinir determinados conceptos constitucionales relativos a las competencias del Estado o al intentar crear un sistema descentralizado de gobierno del poder judicial). En definitiva, el Estatuto suponía en algunos aspectos una reforma implícita de la Constitución y por eso difícilmente podía superar el control de constitucionalidad. Y no lo superó, porque la STC 31/2010 declaró nulos algunos de sus preceptos y reinterpretó otros aspectos del Estatuto muy significativos desde la perspectiva de la identidad catalana (como la alusión a la nación y a la realidad nacional catalana en el preámbulo del Estatuto o la regulación de los derechos lingüísticos en el ámbito de la enseñanza).

La sentencia fue para un sector importante de la opinión pública catalana causa de una gran frustración porque recayó sobre un Estatuto aprobado en referéndum por el cuerpo electoral catalán y que llevaba varios años en vigor. La STC 31/2010 fue además considerada por el nacionalismo catalán como certificación del fracaso de la vía autonomista y como un punto de inflexión que creaba las bases para una «involución del autogobierno», «en los aspectos políticos, competenciales, financieros, sociales, culturales y lingüísticos» (Preámbulo de la Resolución 5/X del Parlamento de Cataluña, por la que se aprueba la Declaración de soberanía y del derecho a decidir del pueblo de Cataluña, de 23.01.2013), en definitiva, como un hito que justificaba su giro hacia el independentismo.

En ese sentido, la STC 31/2010 ha tenido a corto plazo consecuencias políticas claramente desfavorables. Pero es difícil sustraerse a la impresión de que ese riesgo estaba implícito en el imprudente planteamiento del nuevo Estatuto. Por otra parte, el nacionalismo catalán ha exagerado las consecuencias negativas de la STC 31/2010, que no ha supuesto el desahucio de la autonomía, porque el Estatuto de 2006, en su mayor parte sigue en pie, entre otras razones, porque el TC 
ha salvado algunas de sus disposiciones más polémicas mediante su interpretación conforme a la Constitución.

\section{EDUARDO VIRGALA FORURIA}

Lo lógico hubiera sido haber llevado adelante una reforma constitucional a partir de la solicitud de informe que el Gobierno realizó al Consejo de Estado en 2005 y que éste materializó al año siguiente. Tras la reforma constitucional podían haberse abordado las reformas estatutarias. Por el contrario, el Presidente socialista J. L. Rodríguez Zapatero, condicionado por su poco prudente promesa electoral de respetar sin cambios el acuerdo al que se llegara en el Parlamento de Cataluña, y por la victoria del tripartito catalán en las elecciones autonómicas de noviembre de 2003, no se opuso a la aprobación de un Estatuto de máximos en septiembre de 2005. Es cierto que dicho Estatuto fue modificado en las Cortes Generales, pero el texto del mismo contenía numerosos aspectos inconstitucionales (la STC 31/2010 declaró la inconstitucionalidad total o parcial de 14 artículos y estableció la interpretación constitucionalmente correcta de otros 27 preceptos), a pesar de lo cual fue aprobado por la mayoría socialista.

La nefasta gestión del TC en la elaboración de la sentencia sobre el Estatuto catalán, con una tardanza de cuatro años, las filtraciones continuas a la prensa, los cambios de ponentes, las recusaciones, etc., hicieron que la STC 31/2010 no contentase a casi nadie. La sentencia, aun siendo aceptable en mi opinión desde el punto de vista jurídico, fue percibida como un agravio por un importante sector de la ciudadanía catalana, generando un ambiente político propicio para el aumento del independentismo catalán. Pero, lo cierto es que, a pesar de lo anterior, todos los estudios serios de carácter sociológico que se han publicado y las series de encuestas muestran que el aumento del independentismo catalán está más unido a la llegada al Gobierno central del Partido Popular a finales de 2011 y al impacto de la Diada de 2012 que a una hipotética frustración popular por la sentencia de 2010 .

3. ¿Qué analogías y diferencias observa entre el proceso promovido por el nacionalismo catalán y el seguido por el nacionalismo de Quebec o de Escocia? ¿Cree que de esas experiencias debemos aprender algo?

\section{ENOCH ALBERTÍ ROVIRA}

A pesar de tratarse de sistemas constitucionales distintos, creo que los casos de Cataluña, Quebec y Escocia presentan en España, Canadá y el Reino Unido, respectivamente, algunas semejanzas relevantes: se trata de sistemas democráti- 
cos, con una pluralidad de entidades territoriales con identidades singulares que en algunos casos han reclamado la posibilidad de secesión, pero en los que no se contempla para tales entidades el derecho a la autodeterminación. A partir de ahí, se da una circunstancia en Canadá y el Reino Unido que no se ha producido en España: mientras que en estos dos primeros Estados la demanda de autodeterminación de algunas de sus entidades se ha canalizado a través de una consulta popular en estos territorios, con la opción de pronunciarse sobre su voluntad de constituir un Estado propio, en España no se ha permitido esta misma consulta, con el argumento básico, más allá de las alegaciones meramente legalistas, de que la misma, en sí, rompería la soberanía nacional, que reside en el conjunto del pueblo español. Este argumento no ha impedido, por el contrario, que en Canadá y el Reino Unido - también entidades estatales que no reconocen el derecho de secesión a los territorios que las integran y que por tanto se basan igualmente en un principio de soberanía única—se admitiera que estos territorios pudieran celebrar sendas consultas en las que se expresara su población. No se ha tratado, en ningún caso, como tampoco se pidió en España, de referéndums de autodeterminación, esto es, de consultas populares con efectos vinculantes y directos. Se trataba de referéndums de carácter consultivo, que, en caso de resultar ganadora la opción por la independencia de los territorios respectivos, deberían generar un proceso de negociación entre el territorio correspondiente y el Estado (caso del Reino Unido), incluyendo también incluso, además del Estado como tal, el resto de territorios (caso del Canadá). Lo realmente significativo, a mi juicio, es que en estos casos los conflictos suscitados se han resuelto mediante una fórmula no prevista en las Constituciones respectivas, escrita (Canadá) o no (Reino Unido), pero de modo perfectamente pacífico y democrático, permitiendo la expresión de la voluntad de la población de los territorios afectados.

Esta es la solución que ofrece el muy famoso ya Dictamen del Tribunal Supremo del Canadá de 20 de agosto de 1998 (Reference re Secession of Quebec, [1998] 2 S.C.R. 217), en una doctrina que me parece muy pertinente y aplicable también al caso catalán en España, y que enlaza dos proposiciones fundamentales: en primer lugar, no se reconoce ni en el derecho internacional ni en el derecho constitucional interno un derecho a la secesión unilateral de un territorio; pero, en segundo lugar, si la población de un territorio se manifiesta claramente y por una también clara mayoría a favor de la secesión, deberán entablarse negociaciones al respecto entre éste y el Estado y el resto de territorios. La primera proposición de la doctrina del Tribunal Supremo canadiense ha sido recordada en numerosas ocasiones, también por el Tribunal Constitucional español (STC 42/2014, FJ 3). Pero no tanto la segunda proposición. Por ello creo que merece la pena citarla: «el orden constitucional canadiense existente no podría permanecer indiferente ante la expresión clara, por parte de una clara mayoría de quebequeses, de su voluntad de no seguir formando parte del Canadá. EI resto de provincias y el gobierno federal no tendrían ninguna razón válida para negar al gobierno de Quebec el derecho a perseguir la consecución de la secesión, si una mayoría clara de la población de Quebec optara por ello, durante tanto 
tiempo y de forma que, en dicha persecución, Quebec respetara los derechos de los otros. Las negociaciones que seguirian a un voto de este tipo, se referirían al acto potencial de secesión y a sus eventuales condiciones si ésta debiera efectivamente llevarse a cabo. No babría ninguna conclusión predeterminada en derecho sobre ningún aspecto de la cuestión. Las negociaciones deberían tratar los intereses de las otras provincias, del gobierno federal, del Quebec y, de hecho, de los derechos de todos los canadienses en el interior y en el exterior del Quebec, y muy particularmente, de los derechos de las minorías». Creo que esta doctrina, que tiene como presupuesto básico la posibilidad de que la población del territorio concernido pueda expresar su opinión mediante un referéndum consultivo, es perfectamente aplicable a España para resolver el conflicto de Cataluña, y que si no se recurre a la misma es por motivos esencialmente políticos y no jurídico-constitucionales.

\section{ROBERTO BLANCO VALDÉS}

La diferencia fundamental reside en el hecho de que en Quebec y en Escocia los referéndums de autodeterminación se realizaron sin desafiar la legalidad constitucional (Quebec) o fueron consecuencia de un acuerdo entre el Estado y los nacionalistas (Escocia), lo que no ha ocurrido en Cataluña. Aunque de ello podría deducirse, claro, que la responsabilidad del grave conflicto territorial que hoy atravesamos reside en el hecho de que el Estado se haya negado a convocar un referéndum de autodeterminación, mi opinión no es coincidente con tal juicio. Primero, porque las relaciones históricas de Quebec respecto a Canadá y de Escocia respecto al Reino Unido resultan absolutamente incomparables con la de Cataluña respecto a España. Segundo, porque mientras que el Reino Unido carece de una Constitución escrita y la Constitución canadiense no impide la celebración de un referéndum de autodeterminación, nuestra ley fundamental afirma dos principios (el que atribuye al pueblo española la soberanía nacional en el art. $1 .^{\circ} .2$ y el de unidad del art. $2^{\circ} .^{\circ}$ que hacen radicalmente inconstitucional la celebración de tal referéndum en el territorio de Cataluña. Tercera, y no por ello menos importante, porque no existe ninguna experiencia histórica que permita afirmar que las reivindicaciones secesionistas puedan integrarse a través de consultas de autodeterminación. Para ser más precisos, la experiencia de Canadá (con dos consultas sucesivas en 1980 y 1995) y la de Escocia, junto con las de otros territorios donde se han producido procesos de secesión, ponen de relieve que los referéndums se siguen repitiendo indefinidamente (o que esa resulta al menos la pretensión de los nacionalistas que los impulsan) hasta que los partidarios de la secesión los ganan. Así, tras los dos referéndums en los que resultaron derrotados, los nacionalistas quebequeses han planteado en más de una ocasión la necesidad de celebrar un tercer referéndum, que no ha tenido lugar finalmente porque los citados nacionalistas no han obtenido el apoyo parlamentario necesario para sacarlo adelante; del mismo modo, el nacionalismo escocés, defendió, muy poco 
tiempo después de celebrada la primera, la posibilidad de una segunda consulta al pueblo sobre la separación del Reino Unido. Por tanto, y en conclusión, hay muy buenos motivos para sostener, en contra de los que creen que el ejercicio del llamado derecho a decidir desarmaría de argumentos al nacionalismo catalán, que la celebración de un referéndum de autodeterminación pactado entre el Estado central y la Generalitat de Cataluña, lejos de resolver definitivamente o por un largo período de tiempo la reivindicación secesionista, sentaría un precedente político y constitucional que permitía a los nacionalistas exigir la celebración de sucesivas consultas mientras se trataba de mantener viva la movilización popular a favor de la secesión indispensable para poder ganarlas antes o después. Ello significaría, como a nadie se le escapa, que la convivencia interna en Cataluña entre nacionalistas y no nacionalistas, así como la relación entre el Estado y las instituciones catalanas, seguiría deteriorándose por la presión nacionalista para que sucediera de ese modo, pues ese deterioro acabaría por ser en el futuro, como lo ha sido ya hasta ahora, el caldo de cultivo para obtener la victoria en las urnas de la secesión en un eventual referéndum que estaría siempre en el horizonte, hasta que lo ganaran los partidarios de la independencia.

\section{ENRIC FOSSAS ESPADALER}

El proceso catalán se asemeja a los de Quebec y Escocia en el hecho de constituir un intento de secesión promovido por fuerzas nacionalistas en el contexto de una democracia liberal, lo cual plantea nuevos desafíos al derecho constitucional, pues casi ninguna Constitución en el mundo prevé su regulación, que hasta hoy ha sido esencialmente una cuestión de derecho internacional. Pero se diferencia de aquéllos en muchos aspectos: históricos, políticos, culturales y sociales. Y también, claro, constitucionales. He manifestado en alguna ocasión que en Cataluña se da un proceso «eufemístico» de secesión para cuya realización no existe un marco constitucional, y de ahí que sus promotores hayan acudido a conceptos deliberadamente ambiguos y confusos, como el de «transición nacional», «derecho a decidir», «estructuras de Estado», «consultas no referendarias», «elecciones plebiscitarias», o «desconexión democrática», todos ellos destinados a evitar, contornear o vulnerar la legalidad constitucional. Por su parte, el Gobierno central se ha escudado en la Constitución para negar cualquier interpretación o modificación de la misma que permitiera encauzar el problema político catalán. Nada de esto ha ocurrido ni en Quebec ni en Escocia porque en ambos casos se ha llevado a cabo un proceso «constitucional»: ésta es la principal diferencia con el proceso catalán, como han puesto de manifiesto relevantes personalidades políticas y académicas de ambos países (Alex Salmond, Stephan Dion, Michael Keating o Michael Ignatief). Quebec ha celebrado ya dos referéndums (1980 y 1995) amparándose en la Constitución canadiense, y en la ejemplar decisión del Tribunal Supremo de Canadá de 1998, que estableció las reglas que debería seguir una 
consulta constitucional para la secesión de esa provincia. Por su parte, Escocia celebró en 2014 su referéndum acordado (en los Acuerdos de Edimburgo suscritos en 2012 entre el Primer Ministro del Reino Unido y el jefe de Gobierno escocés), y legal (basándose en una reforma de una ley del Parlamento británico, la Scotland Act de 1998). Debe tenerse en cuenta que estos países constituyen dos excepciones pues ninguna democracia avanzada dispone de un marco constitucional para la secesión, y sus respectivas constituciones, de naturaleza bien distinta a la española, no contienen referencias a la soberanía nacional, a la indisolubilidad, ni a los referéndums. De hecho, tampoco Canadá ni el Reino Unido disponían de ese marco, pero con el tiempo lo han ido construyendo para dar respuesta a las demandas democráticas de las minorías nacionales, aunque debe subrayarse que ninguno de los dos países ha reconocido constitucionalmente un derecho a la secesión unilateral. Esa respuesta constitucional se ha ido elaborando con los años, no en unos meses; y a base de diálogo, negociaciones y acuerdos, no adoptando decisiones unilaterales o negando la realidad. Estas son, a mi juicio, las principales enseñanzas que deberían extraer de los procesos de Quebec y Escocia todas las fuerzas implicadas en el proceso, dentro y fuera de Cataluña: el problema catalán debe encauzarse a través de un proceso constitucional (quizá no para resolverlo definitivamente, como tampoco lo han hecho aún esos países), y para ello se requiere tiempo, capacidad de negociación y acuerdo, y cultura constitucional.

\section{TERESA FREIXES SANJUAN}

Los partidos y grupos secesionistas han repetido hasta la saciedad de que el modelo de Escocia y el de Quebec (éste no tanto) podrían haber sido aplicados a Cataluña. Se parte de un [falso] principio consistente en que la negociación entre el Estado y Cataluña lo tenía que haber hecho posible. Este principio, al que también denominan «principio democrático» es, para ellos, lo único que legitima la toma de decisión política, justificando de ese modo la primacía de la democracia, es decir, del voto, frente a la ley, frente al Estado de Derecho.

Hay que señalar en este punto que, tanto en el caso de Escocia como en el Quebec, el pacto político que derivó en la realización de sendos referéndums (varios, en varias etapas históricas) tenía una sólida base legal y allí nunca se emitió el voto fuera de la ley, porque, además, si era necesario reformarla, de mutuo acuerdo se hacía. Quizás ello fue debido a que en el Reino Unido y en Canadá se partía de un pacto de lealtad institucional entre los distintos niveles políticos, el central y el territorial, pacto que evidentemente no existe en nuestro supuesto. Ésta es la principal diferencia entre tales procesos y el que se ha pretendido poner en marcha en Cataluña.

En este punto, es necesario constatar que nuestra Constitución no contiene el principio, que sí existe en otras, como por ejemplo en la de Alemania, de democracia militante. El hecho de no contenerlo implica, jurídica y políticamente, que se 
pueden defender legítimamente ideas contrarias a las regulaciones constitucionales, como por ejemplo, la promoción de la independencia de parte del territorio español. Por ello, ser independentista no es ilegítimo ni contrario a la Constitución. Lo que es ilegítimo y contrario a la Constitución es pretender la independencia de Cataluña, o de otra parte de España, al margen de la ley, sin respetar los procedimientos legalmente establecidos y, aplicando esa torticera regla de la mayoría, proclamar una república catalana e iniciar la construcción de un «nuevo estado» en forma contraria al Derecho interno y al Derecho internacional.

Ahí está la gran diferencia entre los casos del Quebec y Escocia, comparándolos con la deriva secesionista que determinadas fuerzas políticas pretenden instaurar unilateralmente en Cataluña.

\section{JAVIER GARCÍA FERNÁNDEZ}

Con Canadá ninguna analogía y todas las diferencias, posibles. Para algunos constitucionalistas catalanes, Canadá es la versión intelectual de Ítaca, a donde hay que ir a pasar un proceso de éxtasis intelectual que les permite tornar a su tierra con una visión casi divina acompañada de un par de sentencias del Tribunal Supremo. En la operación de legitimación intelectual que prepararon los juristas independentistas, se pusieron a buscar un Estado compuesto donde se hubiera celebrado un referéndum de independencia y lo encontraron en Canadá. Y decidieron mitificar no sólo la experiencia referendaria sino el modelo federal canadiense en su conjunto. Evidentemente, para un jurista europeo el modelo federal alemán o el modelo estadounidense son mucho más ricos que el modelo canadiense, bastante más tosco. ¡Pero los canadienses tenían referéndum que es lo único que les interesaba! Si los juristas independentistas hubieran encontrado un referéndum en la India o en Malasia, allí habrían mandado a los alevines constitucionalistas y todos estaríamos hablando de alguna Sentencia del Tribunal Supremo hindú o malayo.

En cuanto a Escocia, el proceso guarda bastantes diferencias. Por oportunismo, el Premier Cameron convocó un referéndum innecesario, que sólo podía favorecer a los independentistas cuando no conducir a la independencia. Los independentistas catalanes, que siempre han buscado la vía referendaria para forzar la independencia, quedaron maravillados de que todo un Primer Ministro pusiera en riesgo la unidad de un Estado que dura más de tres siglos y se alinearon con el modelo escocés. Pero las diferencias entre la reivindicación independentistas escocesa y catalana son bastantes grandes.

\section{JOSÉ ANTONIO MONTILLA MARTOS}

Las analogías son políticas; las diferencias son jurídico-constitucionales. El proceso político tiene similitudes en cuanto estamos ante crisis territoriales al 
plantearse el debate sobre la integridad de un Estado. Quebec, con sus dos referéndum, había sido el punto de referencia tradicional para las aspiraciones secesionistas. Sin embargo, si comparamos la doctrina establecida por el Tribunal Supremo del Canadá con el procedimiento propuesto por el Consejo Asesor para la Transición Nacional creado por el Gobierno de Cataluña para asesorar en el proceso de secesión, comprobamos que el modelo canadiense se toma sólo en los aspectos que interesan. Así, atendiendo al principio democrático, que se presenta como fuente de legitimidad de todo el proceso, los secesionistas catalanes parten de una concepción obsoleta de la democracia mayoritaria, mientras el Tribunal Supremo canadiense se sitúa nítidamente en la democracia pluralista, que se sustenta en la protección de las minorías. De forma insólita para una democracia moderna se considera que bastaría un voto más a favor que en contra de la independencia para que se debiera producir la secesión a diferencia del modelo canadiense, que exigía una mayoría clara y amplia, así como una preocupación por la situación de las minorías. El caso de Escocia es distinto, aunque también es evidente la influencia política especialmente por su cercanía temporal. La celebración de un referéndum de secesión en 2014 impulsó las reivindicaciones independentistas articuladas en torno al derecho a decidir.

En cualquier caso, más allá de la evidente influencia política, las estructuras constitucionales son distintas. En el caso de España, a diferencia de Reino Unido o Canadá, la celebración de un referéndum sobre la independencia requiere una previa reforma constitucional para modificar el artículo $92 \mathrm{CE}$ o para reconocer expresamente un derecho a la secesión como hacen las Constituciones de Etiopía, Saint Pitts and Nevis o Uzbekistán. Como ha reiterado el Tribunal Constitucional, la Constitución española admite su revisión total y, por tanto, puede incluirse cualquier contenido, también el derecho de secesión, siempre que se haga siguiendo los procedimientos de reforma que la propia Constitución establece y no se prepare o defienda a través de una actividad que vulnere los principios democráticos o los derechos fundamentales.

Por tanto, de la experiencia de Canadá y Reino Unido debemos aprender que cualquier asunto puede ser objeto de debate público, incluida la integridad territorial del propio Estado. Ese debate debe adaptarse, lógicamente, a las estructuras constitucionales de cada Estado, que son distintas. Por ello, en el caso español no cabe ni la cerrazón a plantear la posibilidad de una reforma constitucional para afrontar la crisis territorial ni las actuaciones unilaterales al margen del ordenamiento constitucional.

\section{MIGUEL SATRÚSTEGUI GIL-DELGADO}

Una primera analogía consiste que en ninguno de esos países está reconocido el derecho constitucional a la secesión: en Canadá, el Dictamen del Tribunal Supremo de 20 de agosto de 1998 dejó claro que la secesión de Quebec tan sólo 
resultaría factible si antes se procedía a una reforma de la Constitución federal (2 Supreme Court Reporter (SCR) 217) y en Escocia, el referéndum de 2014 no se realizó en ejercicio de un derecho constitucional de los escoceses, sino en virtud de una autorización especial del Gobierno británico. Otra analogía, de carácter político, es que en ninguno de esos casos las opciones independentistas obtuvieron un apoyo mayoritario por parte del electorado: $49,42 \%$ de los votos en el referéndum canadiense de 1995; 44,7 \% en el referéndum escocés de 2014 y $47,8 \%$ de los votos en favor de las candidaturas independentistas en las elecciones plebiscitarias de 2015 en Cataluña.

Pero las diferencias entre los tres casos son mucho más importantes que las analogías, empezando por las que se refieren a la incorporación al Estado del territorio en el que se ha planteado la secesión (Quebec forma parte de la federación canadiense desde 1867, Escocia se unió a Inglaterra para formar Gran Bretaña en virtud de un tratado en 1707, y Cataluña se integró en la Monarquía hispánica, en virtud de la unión personal de las coronas castellana y aragonesa, en el siglo XVI y después ha participado en la formación del Estado nacional español, de la mano del constitucionalismo liberal, en un proceso histórico con rupturas y retrocesos y en el que la sociedad catalana ha apoyado recurrentemente las soluciones descentralizadoras). Pero volviendo la mirada a la actualidad, lo que más distingue al caso catalán de los otros dos es que las consultas sobre la independencia en Quebec y en Escocia, aunque no existiera un derecho constitucional a la secesión, se plantearon dentro de la legalidad y las fuerzas independentistas asumieron su derrota en los referéndums correspondientes, mientras que en Cataluña los independentistas han planteado un desafío completamente ilegal y no han aceptado el resultado de las elecciones a las que ellos mismos calificaron de plebiscitarias. Esta circunstancia ha tenido consecuencias para la defensa jurisdiccional de la Constitución. Mientras en Canadá, el Tribunal Supremo ha podido realizar un control preventivo y consultivo de la secesión, mediante su famoso dictamen de 1998 — que se refiere a la interpretación del derecho constitucional canadiense para el supuesto hipotético de que se planteara un nuevo referéndum en Quebec y venciera la opción independentista- en España, ante el desafío ilegal del independentismo catalán, el Gobierno ha tenido que acudir sucesivamente al Tribunal Constitucional para reclamar del supremo intérprete de la Constitución que dejara sin efectos la actuación de la Generalitat en el proceso de secesión.

\section{EDUARDO VIRGALA FORURIA}

Hablando desde el punto de vista jurídico-constitucional es difícil señalar analogías y diferencias con ordenamientos constitucionales tan diversos del nuestro como el canadiense o el británico. En el primero, por tratarse de una Constitución parcialmente escrita y de un Estado federal en el que Quebec tiene un peso y una posición en la federación que nada tienen que ver con la de Cataluña en 
España. En el caso del Reino Unido, por su Constitución no escrita basada en la soberanía del Parlamento, pero muy condicionada por la pertenencia a organizaciones internacionales (Unión Europea y Consejo de Europa) y por la jurisprudencia que ha ido adoptando el TS desde su creación en 2009 y muy destacadamente con el concepto de constitutional statutes en la sentencia HS2 Action Alliance v. The Secretary of State for Transport, de 22 de enero de 2014. En todo caso, sigue siendo el Parlamento británico la última autoridad que puede legislativamente cambiar la «Constitución». Eso permitió los acuerdos entre los Gobiernos británico y escocés que desembocó en el referéndum escocés de 18 de septiembre de 2014 y que conduce a que, por ejemplo, el Catedrático de Derecho Constitucional de Oxford, N. Barber ( $«$ The constitutional regulation of scottish secession», en Oxford Legal Studies Research Paper, 2015: http://papers.ssrn.com/ sol3/papers.cfm?abstract_id=2617680), entienda que Escocia, Irlanda del Norte y probablemente Gales tienen ya un derecho de secesión, que les permite decidir en un referéndum territorialmente limitado a los ciudadanos de la parte que quiere independizarse. Este «derecho de secesión» requiere alguna matización, que posteriormente realizaré en la respuesta a la siguiente pregunta.

Sin embargo, sí creo que puede extraerse alguna enseñanza de esos procesos secesionistas y es la de que cuando las encuestas y los resultados electorales muestran que cerca de la mitad de la población es partidaria de la independencia y, probablemente, un porcentaje aún mayor desea ser consultado sobre la relación de un territorio con el resto del Estado, ese dato no puede ignorarse y tampoco cabe repetir, sin más, que el ordenamiento constitucional nada tiene que decir al respecto. En el caso catalán, las elecciones del pasado 27 de septiembre (27-S) han mostrado, por si no lo habían hecho las Diadas de los últimos años, que un porcentaje muy elevado de la población catalana está dispuesto a separarse de España y que es todavía mayor el favorable a la convocatoria de un referéndum sobre el tipo de relación que desean tener con el resto de España. Negarse a reconocer esa realidad, y no proporcionar una salida jurídico-constitucional, es aplazar un problema que irá deteriorándose aún más con el transcurso del tiempo.

\section{4. ¿Qué valoración técnico-jurídica le merece el llamado derecho a decidir? ¿Y la vía de las denominadas elecciones plebiscitarias?}

\section{ENOCH ALBERTÍ ROVIRA}

El llamado derecho a decidir, entendido como la capacidad para que la población de un determinado territorio se pronuncie y decida autónomamente sobre su estatuto jurídico-político, a mi juicio no existe hoy en términos estrictamente jurídicos, en el sentido de que determinados sujetos - reconocidos como titulares del mismo—-puedan ejercer ciertas facultades — reconocidas como su conte- 
nido-con consecuencias que deban ser soportadas por otros sujetos, en cumplimiento o actuación de normas que habiliten su ejercicio y así lo establezcan. Creo que hoy tal derecho, ni en nuestro sistema constitucional ni en los sistemas constitucionales de nuestro mismo entorno jurídico-cultural, al menos hasta el momento, en el estadio actual, no se puede configurar en estos términos, que le otorgarían naturaleza y contenido propiamente jurídicos, aunque el hecho de que esta vía - no prevista jurídicamente en los sistemas constitucionales - se haya practicado en algunos casos para resolver determinados conflictos políticos da pié a que se vaya construyendo también en términos jurídicos, como muestra el Dictamen del Tribunal Supremo del Canadá, citado.

Sin embargo, aunque del mismo no se desprendan facultades exigibles propiamente en términos jurídicos, creo el derecho a decidir expresa, además de una aspiración política legítima como ha reconocido el propio Tribunal Constitucional español (STC 42/2014, FJ 3 y 4), una vía para resolver de forma pacífica y democrática el conflicto político que se suscita entre una minoría — con una base territorial y unas características que le permiten identificarse en términos nacionales, y que cuenta con una voluntad mayoritaria para convertirse en Estado propio- y el Estado del que forma parte y en el que nunca va a poder disponer de la mayoría necesaria para acceder a sus aspiraciones. Y ello no es nada novedoso: ésta es en realidad la doctrina sentada en el Dictamen del Tribunal Supremo del Canadá en el caso del Quebec, al que me he referido ya anteriormente, y que se ha puesto en práctica tanto en Canadá como en el Reino Unido, en el caso de Escocia. No se trata de un derecho jurídicamente exigible — ni a la secesión ni a la consulta_, pero sí una forma de resolver pacífica y democráticamente un conflicto, consultando en primer lugar a la población del territorio en cuestión para después, en caso de que éste se pronuncie a favor de dotarse de un Estado propio, negociar una solución entre todas las partes afectadas.

El hecho de que la vía que expresa el «derecho a decidir», a pesar de no contar hoy con una formulación jurídica formalizada, se haya utilizado para resolver algunos conflictos políticos como los que se han citado, da pié a que vaya adquiriendo consistencia y vaya construyéndose también en términos jurídicos, al menos como principio para enfocar la resolución de este tipo de problemas.

Por otra parte, en relación a las elecciones plebiscitarias, creo que éstas no existen como tales, como una categoría distinta o diferenciada de unas elecciones parlamentarias. Tampoco se han planteado formalmente así en ningún momento en Cataluña. El carácter plebiscitario que se otorgó políticamente a las elecciones del 27 de septiembre al Parlamento de Cataluña fue debido a la imposibilidad de celebrar un referéndum o una consulta específica sobre la creación de un Estado propio en Cataluña, con la consecuencia de que, en estas elecciones, hubo determinados partidos políticos y coaliciones electorales que situaron esta cuestión en el centro de sus programas políticos, forzando de este modo que el resto de fuerzas concurrentes a las elecciones se pronunciaran asimismo sobre la cuestión. De este modo, tal cuestión se convirtió en el centro de la campaña electoral, y los 
electores, de este modo, fueron llamados y tuvieron la oportunidad de pronunciarse sobre la misma. El alto porcentaje de participación electoral (77,5\%), significativamente mayor del que se produjo en anteriores elecciones al Parlamento de Cataluña, demuestra el carácter político especial que tuvieron las elecciones del 27 de septiembre de 2015 .

Sin embargo, al no tratarse de un referéndum sobre una pregunta clara e inequívoca, sino de unas elecciones parlamentarias, los resultados pueden no tener una lectura inequívoca en relación con la cuestión objeto del plebiscito político, de tal modo que pueden no ser equivalentes - y por ello sustituir- a los de una consulta específica. Y ello, es, en efecto, lo que ocurrió en las elecciones del 27 de septiembre de 2015: por un lado, puede establecerse el porcentaje de votos favorables $(47,74 \%)$ o contrarios $(39,17 \%)$ claramente a la opción por la independencia de Cataluña, contabilizando a tal efecto a los votantes de los partidos que se pronunciaron expresamente en uno u otro sentido. Pero hay un grupo de partidos que no se pronunciaron al respecto (sumando el 1,12\% de los votos emitidos) y, sobre todo, un grupo de partidos que se pronunciaron por el derecho a decidir y que no pueden contabilizarse en ninguna de las dos opciones anteriores (Catalunya SíQue Es Pot, con un 8,94 de los votos, y Unió Democràtica de Catalunya, con el 2,51\%, sumando ambos el 11,45\% de los votos emitidos). A mi juicio, esta circunstancia, el hecho de que los resultados no puedan tener una lectura inequívoca, impide que estas elecciones tengan en realidad carácter plebiscitario - en el sentido de permitir que aflore una expresión clara de la voluntad de la ciudadanía catalana sobre la cuestión de la independencia-. Sólo habría habido una lectura inequívoca de los resultados electorales en relación con la independencia de Cataluña - y por tanto, una lectura plebiscitaria de las elecciones- en caso de que alguno de los dos bloques de partidos claramente posicionados a favor o en contra de esta cuestión hubiera obtenido la mayoría absoluta de los votos emitidos, circunstancia que no se produjo.

\section{ROBERTO BLANCO VALDÉS}

Ese pretendido derecho a decidir sencillamente no existe, no está reconocido en ninguna Constitución democrática del mundo, pues ningún Estado regula el proceso de su propia destrucción. El derecho de autodeterminación, que es lo que intenta de encubrirse bajo esa fórmula equívoca del derecho a decidir, fue construido en el ámbito del derecho internacional, por sucesivas resoluciones de Naciones Unidas (números 1514 y 1541 de 1960, 1654 de 1961 o 2625 de 1970), como un instrumento para posibilitar la liberación de las colonias respecto de los Estados a lo que pertenecían. Por eso el derecho a la autodeterminación de los pueblos ha estado siempre vinculado al que tienen las comunidades sometidas al yugo colonial para alcanzar su libertad. El derecho no se construye, por lo tanto, como el que tendría toda comunidad territorial a decidir lo que estime oportuno sobre 
su futuro, cuando y como quiera, sino como consecuencia de la existencia de una situación colonial, que es la única que explica y justifica su ejercicio. Dicho sin rodeos: es la situación política de dependencia colonial y no la democracia la base teórica (de teoría política) sobre la que ha reposado el denominado derecho a la autodeterminación, derecho que dio lugar, sobre todo tras la Segunda Guerra Mundial, a la aparición de un gran número de Estado en los dos continentes, Asia y África, que estuvieron dominados hasta entonces por las grandes potencias coloniales.

Ese derecho a la autodeterminación no constituye, en conclusión, un derecho sustantivo, sino solamente el medio que ha hecho históricamente posible la libertad de los pueblos a los que aquella se le había arrebatado tras ser objeto de conquista colonial. Buena prueba de ello reside en el hecho de que una de las resoluciones de Naciones Unidas referidas previamente (la número 2625) desautoriza plenamente «cualquier acción encaminada a quebrantar o menospreciar, total o parcialmente, la integridad territorial de Estados soberanos e independientes que se conduzcan de conformidad con el principio de la igualdad de derechos y de la libre determinación los pueblos, y estén, por tanto, dotados, de un gobierno que representa a la totalidad del pueblo perteneciente al territorio, sin distinción por motivo de raza, credo o color», de modo que «todo Estado se abstendrá de cualquier acción dirigida al quebrantamiento parcial o total de la unidad nacional e integridad territorial de cualquier otro Estado o país». En consecuencia con todo lo previamente afirmado, lo cierto es que el derecho de autodeterminación de los pueblos formulado por la ONU, no puede servir en ningún caso para justificar las delirantes pretensiones del nacionalismo catalán, pues ese derecho, en su genuina formulación, resulta absolutamente incompatible con toda tentativa de quebrantar la unidad nacional y la integridad territorial de nuestro país, es decir, con toda acción política encaminada a destruir, total o parcialmente, la integridad territorial de un Estado soberano e independiente que, como suceden en el caso de España, se conduce con toda claridad de conformidad con el principio de la igualdad de derechos y de la libre determinación de los pueblos (entendido éste, según se deriva con claridad del Pacto Internacional de Derechos Civiles y Políticos de 1966, cómo el derecho que tiene el pueblo a autogobernarse a través de instituciones representativas) y con un Estado que está dotado de un gobierno que representa a la totalidad del pueblo perteneciente al territorio, sin distinción por motivo de raza, credo o color.

Por si todo lo apuntado hasta aquí no fuera suficiente, desearía, para cerrar la contestación a esta pregunta, añadir una consideración adicional. La defensa del derecho a decidir como un derecho sustantivo del que dispondría cualquier comunidad política-territorial para adoptar por mayoría las decisiones que, al margen de toda legalidad, estimasen oportunas, supondría a ciencia cierta el comienzo de la simple y directa destrucción de democracia y no, como piensan algunos, entre ellos los nacionalistas, una suprema manifestación de la libertad y una expresión prístina del Estado democrático. ¿Por qué? Me parece evidente: porque 
más allá de la insuperable dificultad para determinar con seguridad jurídica cuál podría ser en cada supuesto la porción del pueblo a quien se atribuiría la titularidad de ese derecho (¿por qué atribuir el derecho a una región y no a una provincia, una ciudad o incluso un barrio, como reclamaron en su día los vecinos burgaleses de El Gamonal, defensores de su derecho a decidir si debía o no se construirse allí un bulevar con un aparcamiento subterráneo?), existe un problema de mucha mayor envergadura: ¿Podría el pueblo — definido éste como fuera- reclamar su derecho a decidir por mayoría todo lo que la mayoría, al margen de la ley, quisiera decidir? ¿Podría, por ejemplo, una nación mayoritariamente atea decidir democráticamente la supresión de la libertad religiosa? ¿O una región mayoritariamente antiabortista de un Estado que ha despenalizado en ciertos casos la interrupción voluntaria del embarazo, la celebrar un referéndum para suprimir a la brava en su territorio la legislación nacional vigente en la materia? ¿Sería legítimo ejercer el derecho a decidir para optar sobre privar o no de derecho de voto a los gitanos o a cualquier otra minoría? La cosa no admite duda: la afirmación de ese supuesto derecho a decidir, sobre cuya base se han construido el dislate del llamado proceso de desconexión de Cataluña con España por parte de los nacionalistas catalanes con el apoyo de los restantes nacionalismos periféricos y alguno otro adicional de fuerzas que son nacionalistas sin saberlo, conduciría inevitablemente al caos y convertiría el pacto social en que se basa el gobierno democrático en una caricatura, donde cualquier mayoría ocasional podría hacer mangas y capirotes con el orden de legalidad, los derechos de las minorías y la libertad y la pluralidad que define a cualquier sociedad de ciudadanos libres e iguales.

Por lo que se refiere a las llamadas elecciones plebiscitarias, la respuesta exige menos consideraciones: las elecciones, todas y cualquiera de ellas, no tienen otro objeto que el figura en el decreto de convocatoria. Por tanto no hay elecciones plebiscitarias ni hay más plebiscitos que los que son legalmente convocados como tales. Ello no quiere decir, claro, que cada líder o fuerza política no puede hacer de una determinada elección la lectura que le venga en gana. De hecho, en democracia estamos ya bien acostumbrados a ese fenómeno: después de unas elecciones suele darse frecuentemente el fenómeno no por habitual menos llamativo de que todos han ganado, lo que resulta cuando menos pintoresco. Una cosa más: lo que no es serio es convocar unas elecciones afirmándolas como plebiscitarias, luego esconder tal pretensión ante el revés de las urnas y más tarde volver con él una vez que los datos han sido convenientemente trucados para hacerles decir lo contrario justamente de lo que de ellos se deduce con toda claridad.

\section{ENRIC FOSSAS ESPADALER}

Como he señalado en la anterior respuesta, el llamado derecho a decidir es uno de los eufemismos en los que se ha basado el proceso catalán. En realidad, ha sido la principal base conceptual sobre la que se ha construido el discurso políti- 
co que ha sustentado el proceso (aunque después ha sido abandonado) y la consigna que ha servido para generar la enorme movilización institucional, política, social y mediática que lo ha acompañado. El término se utilizó en la Ley 9/2008, del Parlamento Vasco (Plan Ibarretxe II), y su significado ya era confuso entonces pues la disposición preveía la convocatoria de una consulta a los ciudadanos vascos para saber si estaban de acuerdo en que los partidos iniciaran un proceso de negociación para alcanzar un Acuerdo Democrático sobre el ejercicio del «derecho a decidir» del pueblo vasco, en el que se establecerían las bases de una nueva relación entre la Comunidad Autónoma y el Estado español. La STC 103/2008 declaró inconstitucional este precepto por entender que presuponía la existencia de un sujeto, el Pueblo Vasco, titular de un derecho a decidir, equivalente al titular de la soberanía del Pueblo español, lo cual afectaba al fundamento del orden constitucional vigente y por ello requería una reforma previa de la Constitución. En esta misma revista expresé en su día mi discrepancia con el fundamento de esa resolución. El derecho a decidir se incorporó con la misma ambigüedad a la Resolución 5/X del Parlamento catalán que aprueba la «Declaración de soberanía y el derecho a decidir del pueblo de Cataluña», con la que comienza el proceso soberanista, en la que se acuerda iniciar un proceso «para hacer efectivo el derecho a decidir para que los ciudadanos y ciudadanas de Cataluña puedan decidir su futuro político», y se habla de la necesidad de que el pueblo de Cataluña determine libremente su futuro mediante una «consulta». La expresión puede entenderse como un derecho a ser consultado, o el derecho a convocar a los ciudadanos para conocer su opinión; o como el derecho a que la voluntad de los ciudadanos manifestada en una consulta vincule a los poderes públicos. En cualquiera de estas acepciones, el derecho a decidir, que ha sido un éxito como consigna política, constituye un postulado jurídico inexistente en nuestro ordenamiento, a pesar de algunos intentos teóricos para crear un nuevo derecho, distinto del de autodeterminación, basado en algunos principios constitucionales. Por ello me sorprendió que el Tribunal Constitucional, en la STC 42/2014, que enjuició la Resolución $5 / \mathrm{X}$, diera carta de naturaleza a este derecho mediante una interpretación conforme según la cual no se trata de una manifestación del derecho de autodeterminación sino de una «aspiración política» a la que solo se puede llegar mediante un proceso ajustado a la legalidad constitucional, y que permitiría la apertura de un proceso con la pretensión de modificar el fundamento del orden constitucional. Lo cual, a su vez, llevó a interpretar que esa interpretación del derecho a decidir avalaba cualquier tipo de actividad preparatoria de la separación, antes de la reforma constitucional, incluido cualquier tipo de referéndum o consulta, excepto el de autodeterminación. Ahora bien, debo insistir en que esta debilidad del derecho a decidir desde el punto de vista jurídico, no ha impedido que siga siendo una consigna política que suscita el apoyo de una mayoría de las fuerzas políticas y de ciudadanos en Cataluña, que lo contemplan como una exigencia de ser consultados, de alguna forma, sobre las relaciones que en el futuro deben establecerse entre Cataluña y España. 
En cuanto a las elecciones plebiscitarias, podría decirse que con ellas ha ocurrido algo parecido al derecho a decidir. Se trata de otro eufemismo sin ninguna base constitucional que ha acabado abriéndose paso en el proceso, con el aval del Consell de la Transició Nacional de Cataluña, y a base de su repetición y difusión en la opinión pública. Tales elecciones no existen en nuestro ordenamiento porque no aparecen en ningún manual de derecho constitucional ni de ciencia política ya que se trata hasta cierto punto de un oxímoron: las elecciones sirven para que los ciudadanos elijan entre varias opciones políticas que presentan distintos programas, y en un sistema parlamentario, para dar lugar a la formación del gobierno por parte de aquélla o aquellas fuerzas que logren una mayoría parlamentaria; mientras en los referéndums los ciudadanos se pronuncian sobre una decisión política manifestando su posición a favor o en contra de la misma (o entre dos opciones), y se adopta aquélla que haya obtenido una determinada mayoría de votos. Son dos mecanismos democráticos que se basan en el voto de los ciudadanos, pero que tienen lógicas totalmente distintas, y por ello no pueden confundirse pues las mayorías parlamentarias son una realidad distinta de las mayorías electorales. De ahí que el intento de utilizar uno para conseguir los objetivos del otro lleve a la confusión o a la manipulación a la hora de interpretar los resultados, en votos y en escaños. Así ocurrió en las elecciones catalanas del 27 de septiembre, a las que las fuerzas independentistas atribuyeron el carácter plebiscitario, proponiendo que los sufragios electorales que obtuvieran sus listas se computaran como votos a favor de su programa para la independencia. $\mathrm{Y}$ al igual que el derecho a decidir, se fue asumiendo por todo el mundo la extraña idea de las elecciones plebiscitarias, y de ahí la confusión posterior. En efecto, a pesar de que los votos ciudadanos que obtuvieron las candidaturas independentistas no alcanzaron el $50 \%(47,8 \%)$, y se perdiera por tanto el supuesto plebiscito, al haber obtenido esas fuerzas una mayoría de escaños (62 de Junts pel Sí, que no obtuvo la mayoría absoluta y debe confiar en los 10 escaños de la CUP), entendieron que habían obtenido un «mandato democrático» para llevar adelante la llamada «hoja de ruta» hacia la independencia. Esa errónea e interesada interpretación de los resultados condujo a una situación paradójica dentro del proceso, ya en sí mismo lleno de paradojas: las elecciones «plebiscitarias» permitieron que una mayoría del Parlament aprobara la Resolución 1/X, que proponía el inicio del proceso de creación de un Estado independiente en forma de República y la desconexión del Estado español, pero no hicieron posible una mayoría (al menos en el momento de escribir esta respuesta) para elegir un Presidente de la Generalitat.

\section{TERESA FREIXES SANJUAN}

El denominado derecho a decidir, mal que les pese a quienes lo defienden, jurídicamente no existe. Ningún texto jurídico, nacional, europeo o internacional, lo reconoce ni lo regula. Se trataría, en suma, de un sucedáneo del derecho de autode- 
terminación o de secesión, instituciones jurídicas sobre las que existe consenso unánime que no son aplicables al caso de Cataluña (lo recordó directamente el propio Secretario General de las Naciones Unidas), que ha sido denominado de tan original manera para no centrar el debate sobre lo que jurídicamente no es invocable.

En el fondo, lo que se pretende con tal expresión es justificar, ante propios y extraños, la creación de un nuevo Estado independiente, nada menos que en el seno de la Unión Europea, mediante la realización de una consulta a la población, sin que se hubieran creado las bases jurídicas que la legitimaran.

Sin embargo, hay que señalar en este punto que no es un Estado quien quiere sino quien puede, es decir, quien consigue avanzar en el procedimiento jurídicamente establecido hasta obtener el reconocimiento de la Comunidad Internacional. Lo que equivale a manifestar que se tienen que seguir una serie de pasos, legalmente establecidos, además de superar lo que podríamos denominar fase política del reconocimiento. Sin ello, cosa que puede durar décadas, no hay Estado, por más proclamación política que se haya hecho de ello (se puede preguntar al respecto a saharauis y a palestinos... Entre otros).

De entrada, para que un Estado sea reconocido en el marco de las Naciones Unidas, ha de obtener la mayoría de los votos como tal en la Asamblea General, a propuesta del Consejo de Seguridad de Naciones Unidas, teniendo que cumplir con las condiciones que le impone el artículo 4 de la Carta de esta organización internacional y que son: por una parte, haberse constituido como Estado. Es decir, que se haya formado como tal de acuerdo con los procedimientos legalmente admitidos por la comunidad internacional (que son el respeto a las reglas del Derecho interno en las secesiones pactadas en el marco de un Estado democrático, o, para el caso de dictaduras o territorios coloniales, el ejercicio del derecho de autodeterminación). Por otra parte, se tiene que ser un Estado pacífico, que acepte las obligaciones de la Carta de las Naciones Unidas, sea capaz de asumir estas obligaciones y esté dispuesto a hacerlo. El Tribunal Internacional de Justicia, además, considera, desde sus orígenes, que el cumplimiento de estas condiciones es necesario y, además, suficiente, sin que puedan exigirse el cumplimiento de otras que no estén explicitadas en la propia Carta, que estas condiciones del artículo 4 han de ser interpretadas en contexto y que el voto de los Estados ha de ser individual y objetivo.

Téngase en cuenta, como elemento de reflexión, que la propuesta para el reconocimiento de un nuevo Estado la realiza el Consejo de Seguridad, en donde los cinco miembros permanentes (China, Estados Unidos, Francia, Reino Unido y Rusia) han de votar unánimemente para que la decisión sea válida (arts. 23 y 27 de la Carta de NN.UU.), lo que implica que la oposición de sólo uno de ellos bloquea automáticamente la propuesta sin que la Asamblea General pueda entonces pronunciarse al respecto. En consecuencia, para que se pudiera plantear la formación de un nuevo Estado en relación con Cataluña se tendría que pasar el «filtro» del reconocimiento por Naciones Unidas. Éste es el contexto jurídico/ político en el que tal reconocimiento debe ser situado. 
¿Se ha seguido este filtro en la formación de los nuevos Estados europeos que han surgido como tales en el siglo Xxi? En la práctica totalidad de los casos (sólo hay uno en que no ha sido así, que es el caso del Kosovo) se han seguido los procedimientos establecidos por el Derecho Interno, casi siempre aprovechando la coyuntura de los cambios profundos que supuso la caída del bloque comunista. Sin pretender exhaustividad, pueden señalarse lo ocurrido en la desmembración de la URSS, la disolución de la antigua Yugoslavia y la división de Checoslovaquia.

En el caso de la URSS, su desmembramiento originó que el territorio que ocupaba un Estado derivara en el territorio de quince, aunque Rusia fue considerada como la «heredera natural» de la antigua Unión Soviética y mantuvo las responsabilidades internacionales de ésta, entre ellas la condición de miembro permanente del Consejo de Seguridad de Naciones Unidas. Hay que señalar que en aquel momento estaba vigente la Constitución de la URSS de 1977, que reconocía el derecho de secesión a sus Repúblicas y se había adoptado además una Ley regulando el procedimiento para realizar la secesión en 1990. En este contexto, todos los Estados que se desgajaron de la URSS siguieron, además de los procedimientos regulados en el Derecho interno, el procedimiento establecido por la Carta de Naciones Unidas para ser admitidos en esta organización, admisión que tuvo lugar el 2 de marzo de 1992 (excepto Georgia que entró unos meses más tarde). Dentro de este proceso, un caso especial es el de las tres repúblicas bálticas, Estonia, Letonia y Lituania, hoy Estados miembros de la Unión Europea. El planteamiento jurídico que se siguió en estos casos tenía su fundamento en que estas repúblicas recuperaban la personalidad internacional que ostentaban antes de que la URSS se las anexionara y, tras la proclamación de independencia, fueron admitidas en Naciones Unidas el 17 de septiembre de 1991. También en estos casos se siguió el procedimiento previsto en la Carta de Naciones Unidas, sin que Rusia ejerciera el veto al respecto. La previsión legal/constitucional de la URSS y el procedimiento legalmente establecido para la entrada en Naciones Unidas constituyeron, pues, en su momento, el fundamento jurídico de la creación de estos nuevos Estados.

En el supuesto de la antigua Yugoslavia, ésta, como Estado federal, estuvo compuesta por las repúblicas socialistas de Bosnia y Herzegovina, Croacia, Eslovenia, Macedonia, Montenegro y Serbia, teniendo además dos provincias autónomas dentro de Serbia que eran Voivodina por una parte y Kosovo y Metojia por otra. La Constitución vigente en Yugoslavia en la época de la desintegración era la de 1974, heredera de la de 1963 que a su vez lo era de las de 1953 y 1946. En la Constitución de 1974, se definía a la República Socialista Federativa de Yugoslavia como una unión voluntaria de repúblicas socialistas y de naciones comprendiendo el derecho a la separación (reconocido en los Principios fundamentales) y en el artículo 244 se reconocía que el fundamento del Estado era la «soberanía» de los «pueblos». La puerta abierta hacia la separación, a través de la constitucionalización de la «unión voluntaria», fundamentada en los principios de soberanía y autodeterminación de los pueblos y auto- 
rizando la secesión, constituyó la base jurídica de las proclamaciones de independencia. Sobre estos postulados, Bosnia-Herzegovina, Croacia y Eslovenia fueron reconocidas por las Naciones Unidas en 1992 y la ex República Yugoslava de Macedonia en 1993. Serbia y Montenegro quedaron agrupados en la República Federativa de Yugoslavia, que fue reconocida por la ONU en el año 2000 y, tras la división entre Serbia y Montenegro, la primera quedó como Estado sucesor de la antigua república y Montenegro fue admitido en las Naciones Unidas en 2006. Kosovo se autoproclamó Estado independiente en 2008, sin base jurídica en el Derecho interno de Serbia, donde estaba integrado como provincia, no como república, pero no hay unanimidad ni en Naciones Unidas ni en la Unión Europea sobre su aceptación como tal. De este modo, a partir de las previsiones constitucionales de la República Federativa Socialista de Yugoslavia, y con proclamaciones de independencia, seguidas de referéndum en algunos casos, en lo que fue el territorio de la antigua Yugoslavia, existen hoy seis Estados reconocidos por la Comunidad Internacional, que son Bosnia-Herzegovina, Croacia, Eslovenia, Antigua República Yugoslava de Macedonia, Montenegro y Serbia. Kosovo todavía espera que su situación jurídica se estabilice pues, aunque el Tribunal Internacional de Justicia reconoció en una Opinión consultiva, el 22 de julio de 2010, que tal autoproclamación como Estado independiente no era contraria al Derecho Internacional porque el Derecho internacional general no contiene ninguna prohibición al respecto, el estatus de Kosovo como Estado continúa siendo contestado y está todavía lejos de obtener la unanimidad de la Comunidad Internacional.

En el caso de Checoslovaquia, la Constitución vigente a la caída del socialismo era la de 1968, con las reformas de 1971, que organizaba el Estado federal en dos naciones, ambas prácticamente con los mismos poderes que la Federación y con nacional dual para los ciudadanos de cada una de ellas que eran, a la vez, checoslovacos y, según su adscripción nacional, checos o eslovacos. En el Preámbulo de esta Constitución se reconocía el derecho de autodeterminación, comprendiendo la secesión a ambas naciones. Sobre esta base, se realizó una reforma constitucional en 1991, de la que derivó la Ley constitucional de 1992 que disolvería a Checoslovaquia. Ello originó inmediatamente, el inicio de procesos constituyentes que dieron lugar a los Estados de Chequia y Eslovaquia. Los dos nuevos Estados ingresaron en las Naciones Unidas, siguiendo el procedimiento previsto por la Carta en 1993.

Una reflexión de conjunto en estos procesos de secesión nos lleva a la consideración de que en prácticamente todos ellos existía una base constitucional previa que allanó jurídicamente el camino no sólo de la formación de los nuevos Estados sino también de su integración en las organizaciones internacionales. Las reglas del Estado de Derecho, presentes en todos los estados democráticos actuales, exigen que cualquier decisión que afecte a la ciudadanía se tome mediante los procedimientos legalmente establecidos. Mucho más si se trata de una decisión tan trascendental como es la relativa a la creación de un Estado. Y, si estos proce- 
dimientos no existen en un lugar concreto, hay que esperar a que se creen, como en toda sociedad civilizada.

Por otra parte, con relación a las denominadas elecciones plebiscitarias, nos encontramos otra vez ante un eufemismo que pretende encubrir una toma de decisión no explícita en el marco de la secesión de Cataluña del resto de España. Todo el denominado «procés» ha estado jalonado de tergiversaciones de las instituciones jurídicas, retorciendo los conceptos jurídicos básicos de las democracias actuales.

En las elecciones autonómicas habidas en Cataluña el 27 de octubre pasado, se ha querido, por una parte, utilizar las elecciones como un sucedáneo de plebiscito en los que se tuvieran que contabilizar, de un lado, los votos obtenidos por las formaciones declaradamente independentistas (Junts pel sí y la CUP) y, del otro, los del resto. Por otra parte, se ha pretendido al mismo tiempo la formación de una mayoría en el Parlament formalizada alrededor de los escaños obtenidos por las candidaturas manifiestamente secesionistas. Se ha estado induciendo a confusión a la ciudadanía, puesto que no les quedaba claro si se trataba de unas elecciones o de un plebiscito.

Si se trata de unas elecciones parlamentarias o plebiscitarias (este último concepto, elecciones plebiscitarias, en realidad tampoco existe, puesto que plebiscito es sinónimo de referéndum, aunque con ciertas connotaciones peyorativas, puesto que recuerda votaciones de ensalzamiento del líder propias de democracias débiles, por no decir directamente regímenes totalitarios) la forma de interpretar los resultados es muy distinta. En las elecciones parlamentarias las mayorías se forman por escaños; en los plebiscitos, por votos.

Efectivamente, o se trata de elecciones o se trata de referéndum. Las primeras sirven para formar los parlamentos y, mediante el juego político de mayorías y minorías, formar gobiernos. Los segundos preguntan una cosa determinada a la población, que tiene únicamente la opción de estar o no de acuerdo.

Si se trata de unas elecciones parlamentarias o plebiscitarias (este último concepto, elecciones plebiscitarias, no existe, puesto que plebiscito es sinónimo de referéndum, aunque con ciertas connotaciones peyorativas, puesto que recuerda votaciones de ensalzamiento del líder propias de democracias débiles, por no decir directamente regímenes totalitarios) la forma de interpretar los resultados es muy distinta. En las elecciones parlamentarias las mayorías se forman por escaños; en los plebiscitos, por votos.

De ahí que, una vez realizadas las elecciones, se hagan lecturas totalmente distintas por unos y por otros. Si en lo que nos fijamos es en los resultados en escaños, entre Junts pel sí y la CUP (punto en común entre ambos: separar Cataluña de España) tienen la mayoría absoluta en el Parlament. Si contamos votos, estas dos fuerzas, claras propulsoras de la independencia de Cataluña, no llegan al $50 \%$ de adhesiones, pues se quedan cerca del $48 \%$ del sufragio expresado y alrededor del $33 \%$ del censo de votantes.

¿Por qué con tan escaso apoyo ciudadano se puede conseguir la mayoría absoluta de los diputados en el Parlament? Hay que ser muy conscientes de que ello 
es debido a la perversión del sistema electoral que rige la celebración de las elecciones parlamentarias en Cataluña. Efectivamente nos estamos rigiendo por una disposición del Estatuto de Autonomía, adoptada con carácter provisional para las primeras elecciones al Parlamento catalán, a la espera de que el Parlament aprobara la ley electoral propia en el marco de sus competencias constitucionales y estatutarias. Esa disposición adicional establecía un reparto de diputados por circunscripciones (que son cuatro, las cuatro provincias catalanas) que respondía a la lógica, loable en principio, de primar a las provincias pequeñas (Girona, Lleida y Tarragona) para que el peso de la gran Barcelona (donde se concentra la mayor parte de la población de Cataluña) no fuera usado en detrimento de las necesidades específicas de los territorios pequeños. Sin embargo, este objetivo, legítimo, fue desnaturalizado ya en sus inicios, al configurarse el reparto de diputados de tal modo que, para obtener un escaño en Barcelona, se tiene que obtener, de media, más del doble de votos, casi el triple, que para conseguirlo en Girona, Lleida o Tarragona.

Hay que decir aquí que semejantes argumentos pueden ser esgrimidos en cuanto al efecto del sistema electoral en las elecciones generales, puesto que el «coste» del voto no es equitativo. Pero no es éste el objeto de la pregunta de esta encuesta, por lo que voy a obviar mayores comentarios.

En democracia, la organización del sufragio universal mediante las leyes electorales siempre se ha enfrentado al problema de la igualdad en el sufragio, es decir, en crear un sistema que se aproxime lo más posible a que valga lo mismo el voto de cada persona. Seguramente, en unas elecciones que no se hubieran planteado en el diabólico contexto de las últimas que han tenido lugar en Cataluña, la quiebra del principio de proporcionalidad no se hubiera evidenciado tan rabiosamente como en estos momentos.

Sobre todo porque esos mismos que machaconamente han querido dar un carácter plebiscitario a las elecciones durante la campaña, ahora, cuando estamos no ante sondeos, opiniones o encuestas, sino ante el voto directamente expresado y efectivamente contabilizado, sólo quieren aferrarse, para conseguir sus ilegítimos y antidemocráticos (por anticonstitucionales y sectarios) objetivos, a un resultado en escaños que, aunque les favorece, deriva de un voto que les ha sido mayoritariamente contrario y que únicamente les otorga la mayoría en escaños en tanto en cuanto tal mayoría parlamentaria es fruto de un sistema que puede derivar en pervertir y subvertir lo que la población ha expresado en las urnas.

\section{JAVIER GARCÍA FERNÁNDEZ}

En sentido jurídico la noción de «derecho a decidir» es ajena al ordenamiento español, como se infiere de la Sentencia constitucional 103/2008, de 11 de septiembre, que declaró inconstitucional la Ley vasca que pretendía conceder a los ciudadanos de esas Comunidad Autónoma el derecho a decidir. Esa misma 
Sentencia contenía una idea muy importante: «tal convocatoria [del referéndum que contemplaba la Ley $9 / 2008$, de 27 de junio] no puede ampararse en genéricas potestades implícitas vinculadas al principio democrático (F.J. 3). Y todavía añadió la misma Sentencia: «[e]n realidad, El contenido de la consulta no es sino la apertura fe un procedimiento de reconsideración del orden constituido que habría de concluir, eventualmente, en una 'nueva relación' entre el Estado y la Comunidad Autónoma del País Vasco» (F.J. 4). Y como los independentistas saben que no tiene encaje en el ordenamiento tratan de llevar ese inventado derecho al ámbito internacional [Xavier Pons Rafols: «El denominado derecho a decidir y el Derecho internacional», en Eduard Sagarra (coord.): ¿Existe el derecho a decidir? (Tibidabo Eds., Barcelona, 2014, p. 73], lo que lo hace más irreal todavía.

Estoy convencido de la instrumentalidad política de ese denominado derecho a pesar de la ingenua interpretación que nos dio el Tribunal Constitucional en su Sentencia 42/2014, de 25 de marzo, que, vista la dinámica independentista, cada vez me parece más errónea por la tibieza al juzgar el independentismo catalán. Por no ser, no es siquiera un instituto de Derecho internacional. Es una de tantas falacias inventadas por el aparato de propaganda y agitación de los independentistas. El derecho a decidir se ejercita votando en elecciones libres y no parece que en Cataluña, gracias, al Presidente Mas, haya sequía electoral. Otro tanto se puede decir de las elecciones «plebiscitarias»: las elecciones se emplean bajo unos supuestos y con unos fines y los «plebiscitos» (es decir, los referenda), las pocas veces que se convocan, parten de unos supuestos y buscan unos fines distintos. Es otra falacia de las tantas que ha elaborado, con dinero público, el aparato de propaganda y agitación de los independentistas.

\section{JOSÉ ANTONIO MONTILLA MARTOS}

El derecho a decidir es un puro eufemismo para referirse al derecho de autodeterminación. Dado que el derecho de autodeterminación tiene unos rasgos definitorios en Derecho Internacional que no son aplicables al caso de Cataluña al no tratarse de una colonia ni estar sometido a una potencia extranjera se pretende sustituir por el derecho a decidir, definido como el derecho inalienable de una comunidad política a pronunciarse sobre su futuro político con el sustento del principio democrático. Esta fórmula, ideada en el País Vasco en torno al Plan Ibarretxe, ha fructificado en Cataluña, incluso con sustento doctrinal. Sin embargo, sus premisas son erróneas pues se pretende sustentar en el principio democrático reconocido en la Constitución. Sin embargo, un derecho a decidir amparado en el principio democrático que permita contradecir la propia Constitución, sólo es posible si la Constitución no es democrática. En una Constitución democrática todo derecho debe estar vinculado a ella. No es posible reconocer un derecho «superior» a la Constitución en cuanto permite contradecir sus contenidos, amparado en una hipotética legitimidad democrática. El Tribunal Constitucional lo 
ha expuesto de forma simple en la sentencia en la que anula la Resolución 1/XI, del Parlamento de Cataluña, que declara solemnemente el inicio del proceso unilateral de independencia: «en el Estado social y democrático de Derecho configurado por la Constitución de 1978 no cabe contraponer legitimidad democrática y legalidad constitucional, en detrimento de la segunda», «en una concepción democrática del poder no hay más legitimidad que la fundada en la Constitución» (FJ 5). Por tanto, no puede existir un derecho a decidir en el marco constitucional si se pretende desarrollar sin utilizar los procedimientos que la Constitución establece, en concreto, la reforma constitucional.

En cuanto a las elecciones plebiscitarias apenas merece algún comentario desde la perspectiva jurídico-constitucional. Es un mero artilugio retórico sin mayor alcance, como se ha demostrado en la práctica tras las elecciones autonómicas de 27 de septiembre de 2015. Los partidos que planteaban las elecciones como un plebiscito sobre la independencia luego rechazan leer los resultados como si de un plebiscito se tratara sino que se acogen a la mayoría parlamentaria obtenida, aunque no cuente con el sustento ni siquiera del cincuenta por ciento de los votantes.

En definitiva, la debilidad de estos planteamientos deriva de que son construcciones dogmáticas sin sustento constitucional que pretenden suplantar los cauces constitucionalmente establecidos para el ejercicio de las aspiraciones secesionistas cual es la presentación ante las Cortes Generales por el Parlamento o el Gobierno de Cataluña de una iniciativa de reforma constitucional que permita hacer posible el ejercicio del derecho de secesión.

En este contexto, el Gobierno ha puesto en marcha los mecanismos ordinarios de garantía jurídica de la Constitución y el Tribunal Constitucional ha subrayado lo obvio. Más dudas ofrece la reciente reforma de la LOTC que pretende convertir al Tribunal en un instrumento para la defensa política de la Constitución, tarea que debe corresponder a otros órganos de naturaleza política como los previstos en el artículo $155 \mathrm{CE}$.

\section{MIGUEL SATRÚSTEGUI GIL-DELGADO}

El derecho a decidir es una petición de principio: «Cualquier pueblo con un sentimiento nacional diferenciado tiene derecho a decidir libremente su futuro, incluso a separarse del Estado del que forma parte». Pero jurídicamente se trata de una proposición ineficaz, porque los derechos dependen del ordenamiento, no de postulados ideológicos. Y ni la Constitución española (que en esto se asemeja a las de los demás Estados occidentales) ni el Derecho internacional contemplan un derecho colectivo semejante.

Es evidente que no es posible interpretar los fundamentos de nuestra Constitución, proclamados en sus dos primeros artículos (soberanía del pueblo español y unidad de la nación española), de forma que ampare el derecho a decidir. Otra 
cosa es, como lo reconoce la STC 42/2014, que sea plenamente legítima una acción política orientada a conseguir el reconocimiento constitucional de ese sedicente derecho.

Por otra parte, aunque el Derecho internacional reconoce el derecho de libre determinación de los pueblos (art. 1 del Pacto de Derechos Civiles y Políticos de 1966), lo que el mismo ampara y legitima es la autodeterminación exterior, es decir, el derecho a sustraerse del dominio de un Estado por parte de los pueblos sometidos a dominación colonial u ocupación. Pero ese derecho no puede ser interpretado como justificación o pretexto para amenazar o vulnerar la integridad territorial de Estados soberanos que garantizan la autodeterminación interior de su pueblo: su participación en la vida estatal con igualdad jurídica y sin discriminaciones (Declaración con ocasión del Quincuagésimo Aniversario de las Naciones Unidas, Resolución de la Asamblea General 50/6, de 9 de noviembre de 1995). Dicho de otro modo, aquellos pueblos que no están colonizados u ocupados solamente tienen derecho a la autodeterminación externa si carecen de derecho a la autodeterminación interna. Ese no es el caso de los catalanes que, en virtud de la Constitución española, tienen garantizados sus derechos fundamentales y participan sin discriminación en el Estado democrático de Derecho que la Constitución organiza. Concretamente, desde 1977, han sido llamados a participar, junto con los demás españoles, en diez elecciones municipales, doce elecciones a las Cortes Generales y tres referéndums. Además, han participado en once elecciones al Parlament de Cataluña y en dos referéndums de ese ámbito territorial.

Las fuerzas independentistas que lograron en las elecciones autonómicas de 27 de septiembre de 2015 una heterogénea mayoría de diputados (pero no de votantes) plantean la secesión como un conflicto de legitimidad política y de poder, que debería traducirse en una ruptura con la legalidad (desconexión»), pero no como un pleito que hubiera de resolverse sobre la base del Derecho. En realidad, la secesión que plantean las fuerzas independentistas ni siquiera sería conforme al derecho a decidir, porque no habría sido decidida por los electores, sino por los elegidos, lo que solamente podría aspirar a justificarse en una razón histórica, en el desarrollo de una dialéctica nacional (el llamado «proceso») que habría de culminar en la independencia de Cataluña, incluso sin respaldo electoral mayoritario.

Pero esa dialéctica no tiene que ver con el Derecho, que no admite que la naturaleza jurídica de unas elecciones dependa del propósito de las fuerzas políticas triunfadoras. Estas no pueden dotar a su victoria, en votos o en escaños, de consecuencias ilimitadas.

\section{EDUARDO VIRGALA FORURIA}

A nadie se le escapa que estamos viviendo un proceso de aceleración de las demandas nacionalistas en Cataluña. Las enormes manifestaciones de las últimas 
Diadas, la posición mayoritaria del Parlamento catalán aprobando la Declaración de soberanía de 23 de enero de 2013, la participación de más de 2.300 .000 personas en el proceso participativo del 9 de noviembre de 2014 y el apoyo del $47 \%$ del electorado a listas independentistas en el 27-S, han puesto de manifiesto que un número muy importante de catalanes está dispuesto a continuar un proceso que les conduzca a la independencia de España. Las razones pueden ser muy variadas, desde una mera reivindicación identitaria al presunto expolio fiscal. Creo que a estas alturas eso es lo de menos. Sean cuales sean, ponen el dedo en la llaga del problema fundamental, como es el de la posibilidad de que en un territorio de España la mayoría de sus ciudadanos puedan no estar de acuerdo en vivir bajo el Estado al que pertenecen, a lo que hay que dar una salida jurídico-constitucional.

Pero, dicho lo anterior, jurídicamente no existe el derecho a decidir, ni desde el punto de vista del derecho de autodeterminación ni del derecho de secesión. El derecho de autodeterminación está vinculado al Derecho internacional, y, en ningún caso, se dan en Cataluña las características exigidas por Naciones Unidas. El derecho de autodeterminación está reservado a las colonias sometidas a un ordenamiento jurídico diverso del de la metrópoli ya desde la Declaración sobre la concesión de la independencia a los países y pueblos coloniales (resolución 1514, XV Asamblea General de las Naciones Unidas de 14 de diciembre de 1960), de forma que «todo intento encaminado a quebrantar total o parcialmente la unidad nacional y la integridad territorial de un país es incompatible con los propósitos y principios de la Carta de las Naciones Unidas» y que «ninguna de las disposiciones (de los Pactos Internacionales) se entenderá en el sentido de que autoriza o fomenta cualquier acción encaminada a quebrantar o menoscabar, total o parcialmente, la integridad de los Estados soberanos e independientes que se conduzcan de conformidad con el principio de igualdad de derechos y de la libre determinación de los pueblos (...) y estén, por tanto, dotados de un gobierno que represente a la totalidad del pueblo perteneciente al territorio, sin distinción por motivos de raza, credo o color. Todo Estado se abstendrá de cualquier acción dirigida al quebrantamiento parcial o total de la unidad nacional e integridad territorial de cualquier otro Estado o país» (Resolución 2625 de la XXV Asamblea General de Naciones Unidas, de 24 de octubre de 1970, que contiene la Declaración relativa a los principios de Derecho Internacional referentes a las relaciones de amistad y a la cooperación entre los Estados de conformidad con la Carta de las Naciones Unidas). Con posterioridad se ha extendido a los pueblos objeto de anexión por otros estados (Letonia, Estonia y Lituania en 1990 con la URSS; Eritrea con Etiopía en 1993) y a los pueblos oprimidos por genocidio, violación masiva de derechos, destrucción de su identidad o discriminación política y social grave y sistemática (Bangladesh respecto de Pakistán en 1974, por ejemplo).

En cuanto al derecho de secesión, que una futura reforma constitucional podría establecer, pero que hoy en día no existe, es el reconocimiento interno del derecho de un territorio a independizarse del resto del Estado, que, como se sabe, se ha dado históricamente en muy pocas Constituciones, y, actualmente, 
en las de St. Kitt y Nevis, Etiopia y Uzbekistán. Tanto en Canadá, a partir de 1998 con la Opinión del TS de ese país en el marco de una Constitución parcialmente escrita, como en la «Constitución» del Reino Unido, a partir de todo el proceso que condujo al referéndum escocés de 18 de septiembre de 2014, puede decirse que existe no tanto un derecho de secesión (a pesar de la afirmación antes recogida de Barber) como un derecho de los Parlamentos regionales a convocar un referéndum de independencia si existe una mayoría política clara a favor de tal convocatoria.

Lo que no existe es un hipotético «derecho» a decidir la forma territorial del Estado, popularizado por los nacionalistas vascos (la inconstitucional Ley «Ibarretxe» de 2008 hablaba del «derecho a decidir» en la segunda pregunta del referéndum) y catalanes, y que es inexistente tanto en el Derecho internacional como en el Derecho constitucional interno. Puede utilizarse políticamente, pero jurídicamente no existe un «derecho» a decidir, salvo que, con ello, se quiera hacer referencia al derecho de autodeterminación o al de secesión o a ambos, pero eso es ya más una cuestión de maquillaje político que jurídica. Evidentemente, el derecho a decidir en un Estado democrático lo es a decidir en el marco de la legalidad y las Comunidades Autónomas españolas ni son sujeto del derecho de autodeterminación en sentido internacional ni nuestra Constitución les reconoce en la actualidad poder decidir la salida de España.

En cuanto a las elecciones del pasado 27 de septiembre, han sido, desde el punto de vista jurídico, unas elecciones autonómicas ordinarias en las que concurría una lista unitaria independentista a partir de la coalición CDC y ERC, y luego múltiples listas de todo tipo, hasta el punto de que seis han obtenido representación parlamentaria, haciendo, por lo tanto, muy difícil que la competición fuera realmente «plebiscitaria». Dicho lo anterior, el 27-S nos dice, por si no lo habían hecho las Diadas de los últimos años, que un porcentaje muy elevado de la población catalana está dispuesto a separarse de España y que es todavía mayor el favorable a la convocatoria de un referéndum sobre el tipo de relación que desean tener con el resto de España. Negarse a reconocer esa realidad, y no proporcionar una salida jurídico-constitucional, es aplazar un problema que irá deteriorándose aún más con el transcurso del tiempo.

Pero el 27-S también nos muestra, como lo han hecho las encuestas de los últimos años, que el independentismo catalán está muy lejos de los elevados porcentajes que han solido obtener los secesionistas (media superior al 60\%) en los referendos de aquellos países que han alcanzado la independencia en los últimos setenta años. Solo si se diera un porcentaje de apoyo al independentismo mucho mayor que el expresado el 27-S podría tener alguna virtualidad una declaración unilateral de independencia sin referéndum previo. Incluso en ese momento, únicamente la capacidad de controlar el territorio (puertos, aeropuertos, fronteras, administración pública) y el reconocimiento por Estados extranjeros, y fundamentalmente los europeos o las grandes potencias, permitiría la realidad de una República catalana. 
5. ¿Qué comentarios desea usted hacer a los pronunciamientos del Tribunal Constitucional sobre los pasos que el Govern y el Parlament han dado en esta andadura? ¿Y sobre los dictámenes del Consell de Garantías Estatutarias?

\section{ENOCH ALBERTÍ ROVIRA}

Creo que a lo largo de este proceso se han producido hasta el momento dos sentencias especialmente relevantes del Tribunal Constitucional: la STC 42/2014, de 25 de marzo, sobre la Declaración de soberanía y del derecho a decidir del Parlamento de Cataluña, aprobada mediante la Resolución 5/X, de 23 de enero de 2013, en primer lugar, y la STC 31/2015, de 25 de febrero de 2015, sobre la Ley del Parlamento de Cataluña de consultas populares no referendarias y otras formas de participación política (Ley 10/2014, de 26 de septiembre), en segundo lugar.

Sobre la primera, creo que es importante señalar que, después de declarar la unidad de la soberanía a favor del pueblo español en su conjunto, el Tribunal Constitucional declara también que el «derecho a decidir» es legítimo en nuestro sistema constitucional, como aspiración política que pueden perseguir legítimamente los actores políticos mediante los cauces constitucionales (con la consecuencia de que pueden desarrollar a este fin actividades preparatorias o encaminadas a sostener tales posiciones), al tiempo que el Tribunal llama también a los poderes políticos a dialogar para resolver esta situación de conflicto. El Tribunal, incluso, cita expresamente el Dictamen del Tribunal Supremo del Canadá en el caso de Quebec, aunque, como he dicho ya, se limita a la primera parte del mismo, en la que se declara que ni en el derecho internacional ni en el derecho interno resulta admisible una decisión unilateral de independencia por parte de un territorio. Las alusiones a la legitimidad de todas las posiciones políticas, a los actos preparatorios, al diálogo e, incluso, aunque sea parcialmente, al Tribunal Supremo del Canadá en esta cuestión, hubieran podido inducir a pensar que el Tribunal Constitucional podría admitir la celebración de una consulta no vinculante en Cataluña sobre esta cuestión.

La segunda de las sentencias indicadas (STC 31/2015), sin embargo, deshace esta impresión, pronunciándose rotundamente en contra de tal consulta. Ciertamente, la Sentencia versa sobre la Ley catalana dictada con la finalidad de dar cobertura legal a la celebración de una consulta, no vinculante, convocada de forma unilateral por el Gobierno de la Generalitat, ante la negativa estatal a acceder a la celebración de una consulta o un referéndum acordado con el Estado. Por tanto, el Tribunal Constitucional no se pronuncia propiamente sobre un referéndum o una consulta convocada por el Estado o con la autorización del Estado ex artículo 149.1.32 CE en Cataluña, sino sobre una consulta convocada unilateralmente por la Generalitat de Cataluña. La decisión del Tribunal fue clara y rotunda, en el sentido de equiparar tal consulta con un referéndum y 
considerarla, en consecuencia, a tenor de su doctrina anterior, también muy restrictiva, inconstitucional. No comparto esta interpretación, que sitúa la entera figura del referéndum bajo la órbita de la competencia del Estado (y no solo la facultad de autorización, que es lo que expresamente le reserva la Constitución en su art. 149.1.32 CE), que equipara las consultas no vinculantes a los referéndums y que no tiene en cuenta que la convocatoria de la consulta en Cataluña, de forma expresa en el propio Decreto de convocatoria, se presentó como una consulta a la ciudadanía en el marco de un proceso de reforma constitucional, previa al ejercicio de la iniciativa de reforma por parte del Parlamento de Cataluña, para que la población pudiera pronunciarse antes de que las instituciones catalanas presentaran una propuesta de tan gran calado político. Creo que había margen suficiente, incluso con la anterior doctrina del Tribunal Constitucional, para considerar que la consulta catalana, en los términos en los que se planteó, podía realizarse. Estoy convencido de que si se hubiera permitido la celebración de la consulta (o el Estado, previamente, la hubiera autorizado o bien hubiera delegado a la Generalitat la competencia para hacerlo, tal como se solicitó a las Cortes Generales), siguiendo el ejemplo del Reino Unido o del Canadá, el escenario actual sería muy distinto.

\section{ROBERTO BLANCO VALDÉS}

En lo sustancial estoy de acuerdo con los pronunciamientos del Tribunal Constitucional, respecto de los desafíos a la Constitución y a las leyes impulsados tanto por el Govern como por el Parlament de Cataluña. En concreto considero especialmente relevante la doctrina constitucional contenida en su sentencia de 2 de diciembre de 2015, mediante la cual se declara, por unanimidad, contraria a la Constitución la Resolución independentista 1/XI, de 9 de noviembre, del parlamento de Cataluña. Coincido plenamente con el TCE en la consideración de que tal Resolución está dotada de plena naturaleza jurídica ( «Se trata, por lo tanto, de un acto parlamentario que, sin perjuicio de su veste política, tiene también una indudable naturaleza jurídica; que pone fin, asimismo, a un procedimiento parlamentario, pues constituye una manifestación acabada de la voluntad de la Cámara de inicio o apertura de un determinado proceso político, con independencia de su posterior control parlamentario y, en su caso, del resultado del mismo; y que emana, además, de un órgano capaz de expresar la voluntad institucional de la Comunidad Autónoma»); y coincido también en que la Resolución se aprueba con la obvia e innegable pretensión de producir efectos jurídicos ( «[... ] la Resolución impugnada en cuanto "declara solemnemente el inicio del proceso de creación de un estado catalán independiente en forma de república” y "proclama la apertura de un proceso constituyente [...] para preparar las bases de la futura constitución catalana", en un anunciado marco de "desconexión" del Estado español, es susceptible de producir efectos jurídicos, ya que tales pronun- 
ciamientos pueden entenderse como el reconocimiento a favor de aquellos órganos y sujetos a los que encomienda llevar a cabo esos procesos, especialmente el Parlamento y el Gobierno de la Comunidad Autónoma, "de atribuciones inherentes a la soberanía superiores a las que derivan de la autonomía reconocida por la Constitución a las nacionalidades que integran la Nación española”»).

Por lo demás, mi coincidencia con el Tribunal Constitucional se extiende también a los argumentos esenciales sobre los que el supremo intérprete de la Constitución construye la inconstitucionalidad de la Resolución impugnada. Entre otros, y a saber:

1. Que esa Resolución «permite entender que el Parlamento de Cataluña, al adoptarla, está excluyendo la utilización de los cauces constitucionales (art. $168 \mathrm{CE}$ ) para la conversión en un "estado independiente" (apartado segundo) de lo que hoy es la Comunidad Autónoma de Cataluña. El Parlamento, en efecto, "proclama la apertura de un proceso constituyente (...) para preparar las bases de la futura constitución catalana" (apartado tercero); se compromete a tramitar en determinado plazo una ley, junto a otras, de "proceso constituyente" (apartado quinto); afirma, en tanto que "depositario de la soberanía" y "expresión del poder constituyente", que en el proceso que emprende no se supeditará a las decisiones de las instituciones del Estado español y, en particular, a las de este Tribunal Constitucional (apartado sexto); por último insta al "futuro gobierno" de la Comunidad Autónoma "a cumplir exclusivamente las normas o los mandatos emanados de esta cámara” (apartado octavo)».

2. Que de la lectura de la Resolución 1/XI se desprende de modo inequívoco su consideración como «el acto fundacional del "proceso de creación de un estado catalán independiente en forma de república" (apartado segundo) y a tal efecto se sirve de un lenguaje (futura "constitución", en el apartado tercero, o "soberanía" y "poder constituyente" en el sexto) que se pretende asimismo materialmente "constitucional". Tales términos, sin embargo, figuran en la Constitución española o están presentes en la jurisprudencia de este Tribunal».

3. Que la Resolución 1/XI pretende, en suma, «fundamentarse en un principio de legitimidad democrática del Parlamento de Cataluña, cuya formulación y consecuencias están en absoluta contradicción con la Constitución de 1978 y con el Estatuto de Autonomía de Cataluña. Ello trastoca no solo los postulados del Estado de Derecho, basado en el pleno sometimiento a la Ley y al Derecho, sino la propia legitimidad democrática del Parlamento de Cataluña, que la Constitución reconoce y ampara».

4. Que «en el Estado social y democrático de Derecho configurado por la Constitución de 1978 no cabe contraponer legitimidad democrática y legalidad constitucional en detrimento de la segunda: la legitimidad de una actuación o política del poder público consiste básicamente en su 
conformidad a la Constitución y al ordenamiento jurídico. Sin conformidad con la Constitución no puede predicarse legitimidad alguna. En una concepción democrática del poder no hay más legitimidad que la fundada en la Constitución».

5. Por último, que «el Parlamento de Cataluña ha optado por aprobar, a través del procedimiento parlamentario propio de las propuestas de resolución, la Resolución 1/XI, cuyo contenido incide directamente [...] sobre cuestiones reservadas en su tratamiento institucional al procedimiento de reforma constitucional del artículo $168 \mathrm{CE}$. Por consiguiente, ha de estimarse también vulnerado el citado precepto constitucional, al no haberse seguido el cauce constitucionalmente establecido para abordar una redefinición del orden constitucional como la que se pretende con aquella Resolución».

En cuanto a los Dictámenes del Consell de Garantías Estatutarias mi conocimiento de ellos es menos profundo y por tanto no considero que deba emitir una opinión en esa materia.

\section{ENRIC FOSSAS ESPADALER}

En la anterior respuesta me he referido a la STC 42/2014, que enjuició la Resolución $5 / \mathrm{X}$, sobre la que ya manifesté mi opinión en un comentario en el que consideré que era una Sentencia incorrecta desde el punto de vista jurídico, sin perjuicio de que se pueda reputar acertada desde otras perspectivas. Creo que el Tribunal no dio ningún argumento convincente para justificar que esa resolución parlamentaria producía efectos jurídicos, y podía ser admitida a trámite como una impugnación prevista en el Título V LOTC. Y una vez admitida, llevó a cabo un control de constitucionalidad de una declaración política, llegando a unos pronunciamientos basados en una fundamentación inconsistente, tanto en lo relativo a la soberanía como en lo referente al derecho a decidir, cuya constitucionalidad se salva mediante un uso cuestionable de la técnica de la interpretación conforme, aplicada nada menos que a un texto político.

En cambio, creo que es jurídicamente correcta la STC 31/2015, que declaró la inconstitucionalidad de los preceptos clave la Ley del Parlamento de Cataluña 10/2004, de 26 de septiembre, de consultas populares no referendarias, cuyo propósito era soslayar la preceptiva autorización por parte del Estado de las consultas por vía de referéndum (art. 149.1.32 CE). La aplicación de la doctrina fijada previamente en la ya citada STC 103/2008 y en la STC 31/2010, permitió al Tribunal fundamentar de forma convincente que las «consultas generales» previstas en la Ley eran una verdadera consulta referendaria, cuya regulación corresponde constitucionalmente al Estado. El Consell de Garanties Estatutaries había emitido el Dictamen 19/2014, de 19 de agosto, que avalaba la constitucionalidad 
de la Ley, pero contaba con cuatro votos discrepantes con argumentos similares a los que después utilizó el Tribunal.

La posterior STC 138/2015 resolvió la impugnación de las actuaciones de la Generalitat en el llamado «proceso de participación ciudadana», es decir, el sucedáneo de referéndum organizado para el 9-N de 2014, a pesar de haberse suspendido ex artículo 161.2 CE el Decreto de convocatoria de esa consulta (anulado por la STC 32/2015). Es necesario recordar que la consulta había sido acordada el 12 de diciembre de 2013 por las fuerzas catalanas de forma unilateral. La Sentencia se dictó una vez realizada la consulta, y no enjuiciaba una resolución sino unas simples actuaciones materiales que claramente contravenían la jurisprudencia del Tribunal sobre el referéndum, que aquél se limita a recordar. De ahí que lo más interesante de ese proceso constitucional fuera lo relativo a la suspensión de esas actuaciones, sobre la cual la Sentencia no se pronuncia.

Finalmente, la STC de 2 de diciembre de 2015, que anula la Resolución 1/ XI del Parlament, creo que podía haber realizado un mayor esfuerzo argumentativo para declarar la evidente inconstitucionalidad de esa declaración y aportar algunas consideraciones originales, además de recurrir de nuevo a la STC 138/2015, y a la citada STC 42/2014.

En conclusión, me parece que los pronunciamientos del Tribunal vinculados al proceso adolecen de una cierta debilidad doctrinal, que se une a la ya mencionada debilidad institucional fruto precisamente de las vicisitudes por las que atravesó la STC 31/2010 sobre el Estatuto catalán, y que redundaron en una pérdida de autoridad y credibilidad que no ha recuperado, a pesar de la unanimidad lograda en esos pronunciamientos. Seguramente no ayudará a esa recuperación la involucración del Tribunal en el proceso catalán, promovida por algunas fuerzas políticas con el fin de trasladarle la resolución de conflictos que deben ser tratados en la esfera política. En este sentido, la reforma ad hoc de la LOTC, pensada únicamente para el proceso catalán, y llevada a cabo por el PP con urgencia y sin consenso (Ley Orgánica 15/2015, de 16 de octubre), para atribuir al Tribunal potestades de ejecución de sus resoluciones, incluida la suspensión de cargos públicos, me parece un tremendo error, además de dudosa constitucionalidad.

\section{TERESA FREIXES SANJUAN}

El Tribunal Constitucional ha cumplido con las funciones que la Constitución y su Ley Orgánica prevén para afrontar los temas que ha tenido que tratar durante los últimos años, en relación con el proceso habido en Cataluña. Es más, ha tenido que hacer frente a una estrategia de desprestigio nunca vista ni aquí en España ni en otros países (salvo, aunque por circunstancias muy distintas, en Polonia en la actualidad). El argumentario en torno su falta de legitimidad para pronunciarse en relación con el Estatut de 2006 y las constantes rebeliones que desde el Gobierno y diversas fuerzas políticas se vienen produciendo con la fina- 
lidad de no dar cumplimiento a sus sentencias y resoluciones, constituye una buena muestra de la falta de calidad democrática de quienes lo repiten hasta la saciedad en todas sus intervenciones públicas, especialmente en los medios de comunicación de ámbito catalán, para así crear una opinión pública que ponga en tela de juicio la misma existencia del propio Tribunal.

Ciertamente, sería necesario que se despolitizara la elección de los miembros del Tribunal Constitucional, que no se ofreciera la imagen de «reparto de cromos» con que nos regalan los medios de comunicación cada vez que hay una renovación. No obstante, vista la actuación del TC, que no se puede ver de otra manera que a partir de sus resoluciones, el problema parece estar más en lo que se informa que en el propio funcionamiento del Tribunal. Ello se puede comprobar en que, dejando de lado la sentencia al Estatuto de 2006, el TC ha tratado de dar respuestas lógicas, coherentes y lo más unánimes posibles a lo largo de todas las sentencias y autos que ha dictado durante estos años, ya sea respecto de las declaraciones de soberanía aprobadas por el Parlament de Catalunya, del pseudo referéndum/consulta del $9 \mathrm{~N}$ de 2014 o de la reciente resolución de «desconexión» de España, por citar las más relevantes. Aunque ello no haga moverse ni un ápice a los independentistas en relación con sus propuestas y que los medios de comunicación de ámbito catalán continúan mostrando la acción del TC como si se tratara de un órgano subordinado a políticas estatales antidemocráticas, lo cierto es que las respuestas que viene dando se sitúan en una línea de acuerdo, entre diversas interpretaciones posibles, que otorga relevancia a sus argumentos y decisiones.

La reciente reforma de la LOTC, dirigida a asegurar el cumplimiento de sus resoluciones ha reforzado también el papel que este Tribunal tiene en nuestro sistema constitucional. Dejando a un lado la oportunidad en el momento temporal en que ha sido adoptada, no puede ser entendida más que como el cierre del Estado de Derecho en cuanto a efectividad de las resoluciones jurisdiccionales, máxime cuando se ha introducido también la reforma del recurso de revisión para dar cumplimiento y ejecución a las sentencias dictadas por tribunales supranacionales. No sería lógico que los jueces ordinarios pudieran hacer efectivas sus sentencias (al menos sobre el papel, otra cosa son los problemas de ejecución que día a día aparecen), que también pudieran ser ejecutadas las de los tribunales supranacionales y que las del Tribunal Constitucional pudieran caer en saco roto.

\section{JAVIER GARCÍA FERNÁNDEZ}

La Sentencia de 2 de diciembre de 2015 sobre la Resolución 1/XI del Parlamento de Cataluña es correcta y adecuada frente al acto más desestabilizador de la democracia que ha conocido España desde el 23-F, si bien en algún momento hace algún guiño a las aspiraciones independentistas. Respecto a la Sentencia constitucional 42/2014, de 25 de marzo, fue demasiado tibia y contenía excesivos 
guiños que podían legitimar el independentismo siempre que se discurriera por cauces con constitucionales, actitud que yo no comparto.

En cuanto al Consejo de Garantías Estatutarias, a lo largo de 2015 no he visto ningún dictamen sobre las iniciativas independentistas. Si se repasa su obra a lo largo del último año, no parece que Cataluña está siendo objeto de una operación secesionista. En cambio, viendo los dictámenes de 2015 parece un segundo Consejo de Estado, pues se ha dedicado a informar sobre todas las Leyes estatales, supongo que a la busca de un extralimitación competencial.

\section{JOSÉ ANTONIO MONTILLA MARTOS}

Han sido varias las sentencias en las que el Tribunal se ha pronunciado sobre las actuaciones del Gobierno o del Parlamento de Cataluña en este proceso. En general, puede decirse que el Tribunal ha intentado abordar esta cuestión de forma razonable. Cuando la Resolución del Parlamento de Cataluña lo ha permitido, ha intentado ofrecer salidas al menos jurídico-formales a las aspiraciones independentistas, aun siendo conscientes todos de que pueden estar obturadas políticamente. Es el supuesto de la STC la STC 42/2014 en la que se enjuiciaba la Resolución del Parlamento de Cataluña sobre el derecho a decidir. A mi juicio, la impugnación del Gobierno no debió ser admitida pues estábamos ante una declaración política en la que se presenta a Cataluña como «sujeto político y jurídico soberano» pero se dice expresamente que esa aspiración se articulará a través de los «marcos legales existentes». De hecho, al enjuiciar el fondo del asunto, una vez admitida la impugnación planteada por el Gobierno, el Tribunal declara inconstitucionales y nulas sólo las referencias a la soberanía mientras que las atinentes al «derecho a decidir de los ciudadanos de Cataluña» no son inconstitucionales siempre que sean encauzadas a través de los procedimientos de reforma constitucional que la Constitución prevé. Distinto es el caso de la Resolución 1/XI, del Parlamento de Cataluña. En este supuesto ya no hay referencias a los «marcos legales existentes» sino que, por el contrario, se declara solemnemente que el Parlamento de Cataluña no se supeditará a las decisiones de las instituciones del Estado español, en particular del Tribunal Constitucional. Ahora, por un lado, no estamos ante una mera declaración política que pueda separarse de sus consecuencias jurídicas, sean o no vinculantes. Es imposible separar la declaración política de la concreta regulación pues se presenta al Parlamento como expresión del poder constituyente, se declara el inicio de un proceso constituyente o la desconexión de las instituciones del Estado. Pero, además, por otro, es evidente que no estamos ante un derecho a decidir susceptible de ser encauzado jurídicamente. Estamos ante el inicio de un proceso unilateral de secesión, con la pretendida configuración de un nuevo poder constituyente. Ante ello no cabe encauzamiento constitucional. Por ello, cuando en este supuesto el Tribunal Constitucional se refiere al procedimiento de reforma como vía constitucional 
para encauzar las aspiraciones independentistas lo que está haciendo a mi juicio es afear al Parlamento de Cataluña que haya optado por una vía unilateral al margen de la Constitución en lugar de iniciar un proceso de reforma constitucional, para lo que está legitimado.

\section{MIGUEL SATRÚSTEGUI GIL-DELGADO}

Salta a la vista el importante papel que ha correspondido al TC en la respuesta al proceso secesionista. Probablemente con él se ha intentado compensar la precaria respuesta política del Gobierno al independentismo.

Centraré mis comentarios en los que a mi juicio han sido los principales pronunciamientos del TC en esta materia. En primer lugar, los que se refieren a declaraciones del Parlament de Cataluña con débil apariencia obligatoria, pero que proclaman principios básicos de un nuevo ordenamiento en ruptura con el actual. Ese es el caso de la Resolución 5/X de 23 de enero de 2013, sobre «Declaración de soberanía y del derecho a decidir del pueblo de Cataluña», que reflejó el giro estratégico del nacionalismo catalán a la vía independentista, y de la Resolución 1/XI de 9 de noviembre de 2015, sobre el «Inicio del proceso político en Cataluña como consecuencia de los resultados electorales del 27 de septiembre de 2015».

Para que pudiera ser viable su impugnación, por la vía del Título $\mathrm{V}$ de la LOTC, era preciso considerar que estas Resoluciones no eran solo documentos políticos, sino también jurídicos. Y las Sentencias del Tribunal Constitucional de 25/03/2014 y 2/12/2015 lo justificaron tomando en cuenta sus diferencias con un precedente relevante, de hacía once años: el Auto 135/2004 por el que se inadmitió la impugnación de dos actos del proceso soberanista que entonces se impulsaba en el País Vasco. Se trataba de actos preparatorios e insertos en un procedimiento legislativo (la propuesta de un nuevo Estatuto Político realizada por el Gobierno Vasco y su admisión por la Mesa del Parlamento Vasco) cuyo resultado final, el eventual Estatuto Político, de todas formas podría ser objeto de control de constitucionalidad. En cambio, la Resoluciones 5/X y 1/XI del Parlamento de Cataluña eran definitivas: la primera pretendía determinar un rasgo del ordenamiento de carácter existencial, la soberanía del pueblo de Cataluña; la segunda declaraba solemnemente el «inicio de la creación de un Estado catalán independiente en forma de república» y la «apertura de un proceso constituyente». Y aunque en su defensa el Parlament alegó que esas declaraciones eran expresión meramente política de una aspiración o deseo, el TC rechazó ese planteamiento, porque los efectos de esas Resoluciones, aunque no fueran vinculantes, se proyectaban sobre el Gobierno autónomo, sobre las instituciones de la Generalidad e incluso sobre la ciudadanía. En definitiva, con toda razón, el TC negó que lo jurídico pudiera reducirse a lo vinculante.

Pero con esa interpretación el TC no ha rectificado su rechazo a un modelo constitucional de democracia militante. La Constitución da amparo a un debate 
político desinhibido y libre de restricciones, en el que son legítimas las posiciones políticas abiertamente disidentes, como las independentistas. Pero el principio de constitucionalidad del artículo 9.1 CE no puede justificar que los poderes públicos aprueben resoluciones que nieguen abiertamente la Constitución e inviten a romper con ella ni que las autoridades jurisdiccionales se inhiban de juzgar esas actuaciones, disculpándolas con el criterio de que todo vale (en el fondo), con tal de que parezca que no vale o que vale poco (en la forma).

Otras sentencias importantes del TC en relación con el «proceso» soberanista versan sobre el referéndum. La STC 31/2015 declaró inconstitucional la Ley del Parlamento de Cataluña 10/2014, de 26 de septiembre, de consultas populares no referendarias, en la medida que incluía consultas de «carácter general», sucedáneas del referéndum.

Las bases de su argumentación procedían de la STC 103/2008, sobre la Ley del Parlamento Vasco 9/2008, de 27 de junio y de la STC 31/2010, sobre el Estatuto de Autonomía de 2006. De esa jurisprudencia se desprendía un entendimiento material, tanto de la institución del referéndum (que consiste en una consulta al conjunto de los ciudadanos con derecho de participación política que se lleva a cabo siguiendo el procedimiento electoral), como de la competencia del Estado en relación con la misma (que no se limita a la autorización para la convocatoria de un referéndum, sino que se extiende a la entera disciplina de esa institución).

La STC 31/2015 no se ha desviado de esa interpretación al estimar que las consultas de «carácter general» de la Ley 10/2014 son en realidad referéndums, aunque contemplen un cuerpo electoral ampliado a los mayores de dieciséis años y a los ciudadanos extranjeros residentes en Cataluña y aunque dispongan de una administración electoral ad hoc. En definitiva, queda claro que el referéndum es una excepción en el modelo constitucional de democracia representativa y que no puede haber más referéndums que aquellos previstos en la Constitución y regulados por la ley orgánica que en ese aspecto la desarrolla. Una conclusión diametralmente opuesta a la del Consell de Garanties Estatutàries, cuyo dictamen - aprobado por una mayoría de sus miembros- había avalado una interpretación amplia de las consultas no referendarias que podría convocar la Generalidad.

El Decreto 129/2014 de 27 de septiembre, del Presidente de la Generalitat, de convocatoria de la consulta del 9 de noviembre sobre el futuro político de Cataluña fue también objeto de impugnación conforme al Título V de la LOTC, dando lugar a su suspensión y posterior declaración de inconstitucionalidad (STC 32/2015), en coherencia con la doctrina establecida en la sentencia anterior. Sin embargo, la consulta del 9 de noviembre de 2014 se llevó a cabo, aunque bajo una forma disimulada para fingir respeto a lo decidido por el TC. La realidad puso así en evidencia las limitaciones de la defensa jurisdiccional de la Constitución frente a un movimiento político poderoso - por la importancia de su posición institucional y de sus bases populares- que impulsa un proceso de ruptura, más o menos manifiesto. 


\section{EDUARDO VIRGALA FORURIA}

Creo que los pronunciamientos del TC han sido, por decirlo gráficamente, una de cal y otra de arena. Ha sido coherente, y a mi entender con acierto, en su jurisprudencia sobre los intentos de referéndum y consulta. Por el contrario, creo que no atinó en su sentencia sobre la Declaración de soberanía del Parlamento catalán.

Sobre las leyes de consulta, con el antecedente de las SSTC 103/2008 (Ley Ibarretxe) y 31/2010 (Estatuto catalán), varios juristas (Pérez Alberdi, Roig, Castellà y yo mismo, por ejemplo) ya adelantamos un negro pronóstico para las leyes catalanas 4/2010, de 17 de marzo, de consultas populares por vía de referéndum y otras formas de participación ciudadana (actualmente recurrida y sin sentencia al escribir estas líneas), y 10/2014, de 26 de septiembre, de consultas populares no referendarias, declarada inconstitucional por la STC 31/2015. Desde la STC 103/2008, la convocatoria a, como mínimo, el cuerpo electoral para que ejerza el derecho de sufragio decidiendo cualquier disyuntiva que se le plantee es un referéndum, aunque no reciba esa denominación.

A pesar de que el Consejo de Garantías Estatutarias de Cataluña consideró «que la población potencialmente convocada a una consulta no referendaria no se identifica con el cuerpo electoral y el objeto de la consulta no debe limitarse a las competencias estrictas y tasadas en el Título IV del EAC, sino que podría extenderse al conjunto de funciones y facultades de iniciativa e impulso político que se atribuye en dicha norma a la Generalidad de Cataluña» (FJ 4..$^{\circ}$ ), el TC en su sentencia 31/2015 ha declarado la inconstitucionalidad de la Ley 10/2014. Coincido totalmente con el TC y el referéndum, aunque se le denomine consulta, es competencia de los órganos centrales del Estado en la regulación de sus elementos esenciales y en la convocatoria. Diversas Comunidades Autónomas han previsto en sus Estatutos consultas, que son constitucionales si se trata de «encuestas, audiencias públicas y foros de participación» (STC 31/2010, de 28 de junio, FJ 69), es decir, siempre que no se pregunte para obtener una respuesta vinculante o no, como mínimo, a la totalidad del cuerpo electoral. En este caso, queda la duda de si cabría que la ley orgánica de referéndum se modificara e introdujera el referéndum autonómico. En principio, nada impide que lo haga, ya que no se ha discutido la constitucionalidad de los referendos locales, no previstos constitucionalmente pero sí en la LO 2/1980, de 18 de enero, sobre regulación de las distintas modalidades de referéndum (Disposición Adicional). La LO podría establecer esa posibilidad siempre que los aspectos básicos del referéndum autonómico estuvieran en la propia ley orgánica y la autorización de la convocatoria la realizara el Gobierno central, en virtud del artículo 149.1.32 CE, aunque es cierto que la rotundidad del TC, cuando señala que la regulación estatal «ha de extenderse a la entera disciplina de esa institución, esto es, a su establecimiento y regulación» (STC 31/2010, FJ 69), no augura un futuro prometedor a una hipotética reforma legal en tal sentido. 
De la misma forma, entiendo correcta la STC 32/2015 que anula el Decreto catalán 129/2014, de 27 de septiembre, de convocatoria de la consulta popular no referendaria sobre el futuro político de Cataluña para el 9 de noviembre de 2014, consecuencia directa de la inconstitucionalidad en sentencia previa del mismo día de la Ley 10/2014 de la que traía causa. Como reacción a las previas suspensiones de la Ley y del Decreto de 2014, el Presidente de la Generalitat Artur Mas intentó esquivarlas convocando informalmente, para evitar su impugnación, un proceso participativo para el 9 de noviembre de 2014 en el que voluntariamente se podía responder a las preguntas previstas en el Decreto de 27 de septiembre. Como es conocido, el Presidente del Gobierno impugnó ante el TC las actuaciones de la Generalitat y la STC 138/2015 las declaró inconstitucionales.

Opinión muy distinta me merece la STC 42/2014 que declaró parcialmente inconstitucional la Resolución del Parlamento de Cataluña de 23 de enero de 2013, «por la que se aprueba la Declaración de soberanía y del derecho a decidir del pueblo de Cataluña». La Constitución exige que la impugnación del 161.2 se dirija contra «disposiciones», es decir, normas jurídicas reglamentarias, de rango inferior a la ley, o contra «resoluciones», sobre las que siempre había entendido el TC que eran equivalentes a los actos que ponen fin a un procedimiento administrativo (STC 44/1986) o, en una interpretación amplia, a un procedimiento parlamentario (ATC 135/2004). La Declaración de 2013 no era ninguna de esas dos cosas, por lo que debió inadmitirse la impugnación. La Declaración de soberanía no era una decisión definitiva que produjera efectos jurídicos externos concretos y reales ni que concluyera un procedimiento convirtiéndose, por ello, en acto de carácter resolutorio. En el Derecho parlamentario las mociones, resoluciones, acuerdos o proposiciones no de ley manifiestan la voluntad de un Parlamento y carecen de carácter vinculante desde el punto de vista jurídico.

El TC con una floja e ininteligible argumentación, entendió que «lo jurídico no se agota en lo vinculante» y que la Declaración «es susceptible de producir efectos jurídicos», ya que «puede entenderse como el reconocimiento en favor de aquellos a quienes se llama a llevar a cabo el proceso en relación con el pueblo de Cataluña (especialmente el Parlamento de Cataluña y el Gobierno de la Generalitat), de atribuciones inherentes a la soberanía superiores a las que derivan de la autonomía reconocida por la Constitución a las nacionalidades que integran la Nación española». Uno se pregunta cómo una declaración parlamentaria puede producir atribuciones inherentes a la soberanía. No para ahí el Tribunal, sino que llega a decir que «reclama el cumplimiento de unas actuaciones concretas y este cumplimiento es susceptible del control parlamentario previsto para las resoluciones aprobadas por el Parlamento (art. 146.4 del Reglamento del Parlamento de Cataluña)». Las actuaciones concretas serían decisión autónoma del Gobierno catalán y no producidas mecánicamente por la Declaración y, entonces, serían aquellas actuaciones las controlables, como cualesquiera otras, no solo parlamen- 
taria sino jurisdiccionalmente si se impugnaran. En todo caso, establecido lo anterior, era lógico declarar que parte de su contenido chocaba frontalmente con la soberanía nacional que reside en el pueblo español.

6. ¿Cree usted aplicable y útil para los supuestos indicados en las preguntas inmediatamente anteriores el que el Estado actuase al amparo de las previsiones del artículo 155 CE?

\section{ENOCH ALBERTÍ ROVIRA}

No creo que la resolución del conflicto político existente pase por la aplicación de medidas coercitivas, por el recurso a la fuerza y la imposición, como representa el artículo $155 \mathrm{CE}$. Creo que ello no sería ni adecuado (el conflicto político debe resolverse por medios políticos) ni eficaz (¿qué medidas se aplicarían? ¿por cuánto tiempo? ¿qué sucedería después?).

\section{ROBERTO BLANCO VALDÉS}

El artículo 155 forma parte de la Constitución como cualquiera de los otros que la conforman y fue aprobado en su día, como es obvio, con la misma mayoría parlamentaria y popular. Su texto está tomado de forma casi literal del artículo 37 de la Ley Fundamental de Bonn, que regula la llamada coacción federal: «1. Si un Land no cumpliere los deberes federales que la Ley Fundamental u otra ley federal le impongan, el Gobierno Federal, con la aprobación del Bundesrat, podrá adoptar las medidas necesarias para obligar al Land al cumplimiento de dichos deberes por vía coactiva federal. 2. Para la ejecución de las medidas federales coactivas, el Gobierno Federal o su representante tiene el derecho de impartir instrucciones a todos los Länder y a las autoridades de los mismos». ¿Quiero ello decir que la aplicación de ese artículo sería, en su caso, equivalente políticamente a la de la mayoría de los que componen nuestra ley fundamental? En absoluto: quiere decir sólo que su inclusión en nuestro texto constitucional no es una adherencia extraña de naturaleza autoritaria, sino una previsión perfectamente explicable en un Estado descentralizado, que cuenta con antecedentes en textos constitucionales que han tenido una gran influencia en el derecho federal comparado; y quiere decir que si llegase a darse el supuesto de hecho que justifica la aplicación del 155 habría que hacerlo, pues ha sido incluido en la Constitución con esa finalidad y no con la de que sea letra muerta.

Aclarado lo cual, debo añadir que estoy plenamente de acuerdo con la decisión del Gobierno de Mariano Rajoy de no haber recurrido hasta la fecha a la aplicación de ese precepto, pero también convencido de que si las instituciones autonómicas 
catalanas —el Govern y la mayoría del Parlament — optasen finalmente, como se han cansado de anunciar, por dar cumplimiento a cualquiera de las previsiones en ella contenidas y por desobedecer, así, de forma evidente e incontestable, la sentencia de 2 de diciembre de 2015 del Tribunal Constitucional que, en los clarísimos términos que antes he apuntado, ha declarado contraria a la ley fundamental la resolución independentista del Parlament de 9 de noviembre del mismo año, antes o después, y probablemente mejor antes que después, habría que adoptar medidas a partir de las previsiones contenidas en el artículo 155 de la Constitución. Y ello porque el gravísimo desafío del secesionismo catalán no puede acabar convirtiéndose en un interminable juego de ping-pong, en el que el nacionalismo catalán va subiendo la apuesta de la desobediencia y el Estado se limita a ir impugnando todas y cada una de las resoluciones a través de las cuales aquella desobediencia se concreta. Esa forma de hacer frente al desafío secesionista tendría sin duda, y a no mucho tardar, una traducción tan peligrosa como fácil de prever: que la posición de los independentistas sería cada vez más fuerte y la del Estado, paralelamente, cada vez más débil, como fruto de una estrategia del Estado que no cabría sino calificar como suicida. Por tanto, y en conclusión, la aplicación o no de medidas que encontrasen su justificación en la puesta en práctica de las previsiones contenidas en el artículo 155 de la Constitución sólo depende del secesionismo catalán, como dependió en su día del nacionalismo vasco. Entonces no hubo necesidad de recurrir al citado precepto, porque los nacionalistas vascos acabaron por aceptar las reglas de juego. Si los nacionalistas catalanes siguen empeñados en destruirlas, como hasta ahora, antes o después la aplicación del artículo 155 será sencillamente inevitable. Y ellos y sólo ellos serán los responsables de esa aplicación.

\section{ENRIC FOSSAS ESPADALER}

Los supuestos a los que se refiere la pregunta imagino que son la realización de la consulta del 9-N, a pesar de la suspensión por parte del TC del Decreto de convocatoria y de las actuaciones subsiguientes; y la aprobación por el Parlament de la Declaración 1/XI, también suspendida, que inicia el proceso de desconexión del Estado, a cuyas instituciones dice que no se someterá, en particular al TC, e insta al futuro gobierno a cumplir solo las normas emanadas del Parlament. Podría pensarse que, en principio, ambos encajan en el alguno de los supuestos previstos en el artículo $155 \mathrm{CE}$ : suponen un incumplimiento de obligaciones constitucionales y legales; o una actuación que atentara al interés general de España. Pero es discutible que la desobediencia de una resolución del TC, en este caso suspensiva, sea en sí misma suficiente para aplicar el artículo 155 CE. Por otra parte, este precepto no se ha aplicado hasta hoy, como tampoco se ha aplicado nunca la coerción federal de la Ley Fundamental de Bonn (art. 37), en la cual se inspiró el artículo $155 \mathrm{CE}$, quizá porque de lo que se trata es de «saber no usarlo», o de hacerlo con mucha prudencia. Por otra parte, el precepto español 
exige que sea primero el Gobierno quien requiera al Presidente de la Comunidad Autónoma, y solo en caso de no ser atendido ese requerimiento se adopten las medidas necesarias para el cumplimiento forzoso de las obligaciones, previa aprobación por mayoría absoluta del Senado. Entre esas medidas está previsto que el Gobierno dé instrucciones a todas las autoridades de la Comunidad Autónoma, que las suspenda en sus funciones o incluso que las sustituya. No estoy seguro que todas esas medidas fueran proporcionadas, como requiere el precepto, ni que fueran útiles para poner fin a ese eventual incumplimiento de una resolución del TC, que por otra parte es perseguible penalmente, como ya se ha hecho. Ello quizá explique la mencionada reforma exprés de la LOTC, impulsada con urgencia por el PP para hacer frente a nuevos incumplimientos de la Generalitat en el desarrollo futuro del proceso. Sin embargo, ya he señalado que la reforma atribuye al TC potestades para la ejecución de sus resoluciones de dudosa constitucionalidad, en concreto, la suspensión en sus funciones de las autoridades responsables de su incumplimiento. Estas medias se contemplan en muchos ordenamientos europeos, en los que se ha atribuido al Tribunal Constitucional funciones de impeachmen para juzgar a altas autoridades del Estado o de las autonomías mediante ese procedimiento nacido en el Derecho inglés.

\section{TERESA FREIXES SANJUAN}

Si se dieran los supuestos necesarios, ¿por qué no? La Constitución española es toda ella normativa, es decir, que sus artículos pueden y deben ser aplicados en toda su extensión (algunos directamente y otros mediante ley de desarrollo, cuando así sea dispuesto por ella misma). El artículo 155 instaura un procedimiento mediante el cual se garantiza que las autoridades autonómicas cumplan con sus funciones constitucionales.

Aquí cabe señalar que, frente a las opiniones, que las ha habido, consistentes en que este artículo 155 precisa de una ley de desarrollo para ser aplicado, ello no es necesario puesto que es el propio artículo quien describe con cierto detalle cómo debe aplicarse. Así, el artículo establece:

- El supuesto habilitante: el incumplimiento de obligaciones constitucionales o legales, o una actuación que atente gravemente al interés general de España. Se trata de situaciones alternativas que puedan ser originadas por una Comunidad Autónoma: incumplimiento legal o inconstitucional o actuación que atente gravemente al interés general de España. No es necesario que concuerden ambas situaciones, pues la Constitución las relata con una disyuntiva «0».

- El inicio del procedimiento: requerimiento del Gobierno al Presidente de la Comunidad Autónoma para que cese la actividad incorrecta de la Comunidad. 
— Traslado de la situación al Senado si la Comunidad Autónoma no proporciona debida respuesta cesando en la actividad que ha generado el problema.

- Análisis de la situación por parte del Senado, fijando debidamente el origen de la controversia y aceptando, o no, por mayoría absoluta, la propuesta de intervención que realice el Gobierno para zanjar la situación. Si el Senado no acepta, la intervención propuesta por el Gobierno no puede realizarse.

- Emisión de instrucciones a las autoridades de la Comunidad Autónoma, para hacer efectiva la resolución del Senado.

Estamos, pues ante un procedimiento perfectamente definido, que no precisa de ley de desarrollo para ser aplicado. Tras las elecciones generales habidas el 20 de noviembre de 2015, corresponde ya al Pleno del Senado, donde el Partido Popular cuenta con mayoría absoluta, la toma de decisión al respecto, salvo en el caso de una hipotética disolución de las cámaras si no se llega a un acuerdo, debido a la fragmentación política del Congreso de los Diputados, para la investidura de un Presidente del gobierno; entonces volvería a ser competente la [nueva] Comisión Permanente del Senado.

Es necesario también señalar que no se trata, como vulgarmente ha sido denominado, de una «suspensión de la autonomía». De lo que se trata es de una intervención en las competencias de la Comunidad Autónoma, en los sectores precisos señalados en la resolución que, en su caso, emita el Senado, que deberá ser llevada a cabo por la propia Comunidad Autónoma o, en caso de resistencia a la misma, por las autoridades que sean designadas a tal efecto por el Gobierno. La intervención puede tener distintos grados de intensidad, en dependencia de las materias competenciales afectadas, no sólo en cantidad, sino teniendo en cuenta su relevancia política. Nótese también que la iniciativa para desencadenarlo es política y que son órganos políticos los que intervienen en el mismo; pero son medidas que tienen un alcance jurídico indiscutible, puesto que de su incumplimiento derivan responsabilidades que no excluyen las propiamente penales. Este procedimiento político, como todos los de tal naturaleza, sería controlable jurisdiccionalmente en todos sus elementos reglados.

Evidentemente, éste es uno de los instrumentos con que cuenta el Estado de Derecho para asegurar el cumplimiento de la Constitución y las leyes. No se trata de la única respuesta posible a un desafío por parte de las Comunidades Autónomas, puesto que existen muchas otras medidas en el ordenamiento jurídico que contribuyen a asegurar el orden constitucional, Código Penal incluido, aunque no únicamente éste.

\section{JAVIER GARCÍA FERNÁNDEZ}

Sin duda. El artículo 155 es un precepto incorporado a la Constitución para hacer frente a ciertas situaciones de quebrantamiento del orden constitucional, 
no por parte de grupos o individuos (para lo que está el artículo 116) sino de manera específica por parte de una Comunidad Autónoma. No me ofrece dudas que si se hace necesario, conviene aplicarlo y, añado, si es necesario, en concurrencia con el Código Penal, aunque la reforma de 2015 ha sido una ocasión perdida para tipificar conductas de apariencia pacífica (y hasta «democrática» (adjetivo que los independentistas prostituyen varias veces al día) pero cargadas de una agresividad institucional.

Evidentemente, el problema político es determinar cuándo es el momento oportuno de aplicar las medidas excepcionales del artículo 155 pues no conviene precipitarse y hay que tener el temple del caballero del Libro del Conde Lucanor que demostró su valor sin lanzarse antes de tiempo a combatir a los sarracenos.

\section{JOSÉ ANTONIO MONTILLA MARTOS}

Hasta este momento, el conflicto se ha desarrollado básicamente en el marco de las declaraciones políticas sin que se advierta de forma flagrante el presupuesto habilitante de las medidas coercitivas a que se refiere el artículo $155 \mathrm{CE}$ : incumplimiento de las obligaciones que la Constitución u otras leyes le impongan o actuaciones que atenten gravemente al interés general de España. Sin embargo, de hacerse efectivas las previsiones de la Resolución 1/XI del Parlamento de Cataluña parece evidente que estaremos ante ese supuesto de hecho. No habrá más remedio que aplicar el mecanismo constitucional con las dificultades que ello conlleva tanto desde una perspectiva política como jurídica. Desde lo político pues supondrá sin duda un agravamiento de la crisis territorial, entrando en una dialéctica acción-reacción de consecuencias imprevisibles. Desde lo jurídico pues no existen precedentes de su utilización y no hay ningún desarrollo normativo que concrete el procedimiento de actuación, el alcance de las medidas, etc. En cualquier caso, me parecen más adecuadas estas medidas de coerción que las previstas en la LO 15/2015, de modificación de la LOTC al hilo de la ejecución de sentencias constitucionales. En primer lugar, porque este cauce tiene un reconocimiento constitucional, y es difícil aceptar limitaciones a la autonomía en virtud de previsiones legislativas, sin sustento constitucional. En segundo lugar, porque el 155 CE atribuye la adopción de las medidas a órganos políticos como son el Gobierno y el Senado mientras que la LO 15/2015 deriva la actuación al Tribunal Constitucional, situándole en el centro de un grave conflicto político-territorial.

\section{MIGUEL SATRÚSTEGUI GIL-DELGADO}

Hasta ahora no ha habido necesidad de utilizar el artículo 155 CE, pero está sin duda disponible, porque los preceptos de una Constitución normativa no decaen por desuso y si la Generalitat intenta llevar a cabo un proceso de ruptura 
o «desconexión» conforme a la hoja de ruta marcada por la declaración independentista del Parlament del 9 de noviembre de 2015, esa situación podría subsumirse sin ningún esfuerzo interpretativo en el supuesto que legitima la aplicación del artículo $155 \mathrm{CE}$ : «Si una Comunidad Autónoma no cumpliere las obligaciones que la Constitución u otras leyes le impongan o actuare de forma que atente gravemente al interés general de España,..». Sin embargo no parece tan sencillo interpretar lo que este precepto permite hacer al Gobierno. Apuntaré, a modo de tentativa, algunas ideas y comentarios.

La activación del artículo $155 \mathrm{CE}$ requiere cumplir dos requisitos procesales: el requerimiento al Presidente de la Comunidad y si no fuera atendido, la aprobación por el Senado de las medidas propuestas. Respecto de lo primero, hay que tener en cuenta que sería imposible cumplir con el requisito del requerimiento si faltase un destinatario en condiciones de atenderlo, que es lo que podría suceder en caso de que estuvieran suspendidos en sus funciones todos los miembros del Gobierno autonómico, por aplicación de la reciente reforma de la LOTC (art. 92). En esa situación la Generalidad carecería de un Presidente capaz de actuar, porque la Ley catalana 13/2008 llama a la suplencia o a la sustitución del Presidente exclusivamente a los miembros del Consejo de Gobierno, conforme a un orden determinado. Por eso, mientras estuvieran todos ellos suspendidos en sus funciones, no parece que pudiera activarse el artículo 155 CE. En relación con el segundo requisito, el Reglamento del Senado, en su artículo 189, señala que lo que se debe someter a la aprobación de esa cámara es un escrito en el que el Gobierno manifieste «el contenido y alcance de las medidas propuestas». En otras palabras, el objeto de la votación no son las «medidas» mismas (es decir, los actos o normas jurídicas que se dicten para darles forma), sino una propuesta descriptiva de ellas suficientemente precisa (que el Senado puede aprobar con «condicionamientos o modificaciones»). A la vista del artículo 155.2 CE tampoco parece que se deban votar por el Senado las instrucciones que el Gobierno dirija a las autoridades autonómicas para ejecutar las «medidas». Y aunque para aprobar el escrito con las «medidas propuestas» bastaría la mayoría absoluta de los senadores, en atención a la importancia de esta decisión, sería conveniente que esa mayoría fuera muy inclusiva, por la diversidad política y territorial de quienes la compongan.

Entrando en el contenido del artículo $155 \mathrm{CE}$, este tiene el significado principal de habilitar al Gobierno para intervenir directamente en la actuación de la Comunidad Autónoma, sin necesidad de llevarla a juicio. Por lo tanto ese precepto hace posible una respuesta al proceso secesionista que no sería en primer término jurisdiccional, sino gubernativa y en consecuencia, más ágil e inmediata. Su aplicación tendría la ventaja — no menor- de evitar que se desgaste el Tribunal Constitucional ejerciendo de dique de contención del proceso secesionista. Como contrapartida, el Gobierno tendría que soportar el coste y la responsabilidad política de enfrentarse a ese proceso sin escudarse en los tribunales (en este sentido, Tomás de la Quadra-Salcedo, «El ar- 
tículo 155 de la Constitución: ¿entre Escila y Caribdis?», AHORA, n 4, 13-19 de noviembre de 2015).

El artículo 155 CE no tipifica las «medidas» que permite adoptar al Gobierno y posibilita una utilización del mismo flexible y adecuada al desafío de la Comunidad Autónoma. Pero las «medidas» en ningún caso pueden suspender formalmente la autonomía, que conservaría sus rasgos estructurales, aunque en sus aspectos funcionales estaría afectada por la habilitación al Gobierno para intervenir en su actividad con dos parámetros finalistas: obligar a la Comunidad Autónoma al cumplimiento forzoso de sus obligaciones o proteger el interés general. Significativamente la Constitución añade este segundo objetivo con una conjunción disyuntiva, que avala la posibilidad de una intervención gubernamental con una finalidad distinta a la de restablecer la legalidad. Dicho de otro modo, al amparo del artículo $155 \mathrm{CE}$, el Gobierno podría prohibir no solo las actuaciones autonómicas ilegales sino también las que resultaran inconvenientes o perturbadoras para el interés general (por ejemplo, las gravemente perjudiciales para la situación económica).

Desde el punto de vista sustantivo, las «medidas» podrían tener un significado muy variado; sus mandatos podrían consistir por ejemplo en prohibir, paralizar, dejar sin efecto, derogar o revocar, pero también en ordenar o en regular. Y aunque la Constitución no señala ningún límite material explícito para las «medidas», parece que el artículo 155 CE no está destinado en principio a destituir o suspender a las autoridades autonómicas, porque ellas deben cumplir las instrucciones que el Gobierno les dirija para el cumplimiento de las «medidas» (y asumir también las consecuencias administrativas o penales que se puedan derivar del incumplimiento de esas instrucciones).

En cuanto a su naturaleza jurídica, puede aventurarse la interpretación de que las «medidas» del artículo $155 \mathrm{CE}$, cuyo contenido y alcance haya aprobado el Senado, tendrán fuerza de ley porque desplazarán o excepcionarán los efectos del Estatuto de Autonomía y del conjunto del ordenamiento autonómico. Y eso será así con independencia de que las «medidas» revistan la forma de simples decretos. Por el contrario, las instrucciones que el Gobierno pueda dirigir a las autoridades autonómicas para el cumplimiento de esas «medidas», tendrán carácter administrativo. En todo caso, unas y otras deben estar sometidas a los controles propios del Estado de Derecho y la Comunidad Autónoma podrá impugnar las «medidas» ante el TC, conforme a lo previsto en el artículo 27.2.b de la LOTC, y las instrucciones ante los tribunales ordinarios.

En vista de todas estas características parece, en principio, que el artículo $155 \mathrm{CE}$ podría ser un instrumento útil para contener el desafío secesionista de una Comunidad Autónoma, pero por virtud de su aplicación no está garantizado en modo alguno que aquél se desactive ni que disminuya el número de los independentistas. Ese resultado no se logrará a no ser que durante el período de aplicación del artículo $155 \mathrm{CE}$-que preferentemente debería ser breve- se alcancen acuerdos entre las fuerzas políticas para encaminar la situación política de la Comunidad Autónoma en un sentido constructivo. 


\section{EDUARDO VIRGALA FORURIA}

La coacción estatal prevista en el artículo 155 de la Constitución es la medida más extraordinaria en el Estado autonómico y ha de ser el último recurso cuando no quede ninguna otra posibilidad de que los órganos de una Comunidad Autónoma retrocedan en su ataque al interés general de España. En todo caso, antes de iniciarse este procedimiento deben realizarse los correspondientes requerimientos a los órganos autonómicos y agotarse todos los medios posibles de control judicial a los que me he referido en la respuesta a la última pregunta. En su virtud no cabría una suspensión general e indefinida de la autonomía catalana, por vulnerar el artículo $2 \mathrm{CE}$, pero mientras las medidas permitan el retorno al funcionamiento ordinario de los órganos autonómicos en un plazo prudencial (fijado expresamente), creo que no puede descartarse ninguna que ayude al restablecimiento de la situación y, en concreto, la suspensión y sustitución de los órganos autonómicos al estilo de la Sequestration alemana, admitida por su doctrina. En todo caso, ¿qué puede hacerse al día siguiente de suspenderse la autonomía si una mayoría parlamentaria ha tomado la decisión de declarar la independencia? Podría llegar a proclamarse el estado de sitio (arts. 116.4 y 55.1 CE) si existiera una insurrección o acto de fuerza desde los órganos autonómicos catalanes que hiciera necesaria la intervención del Ejército y la dependencia de éste de los Mossos d'Esquadra (art. 32 Ley Orgánica 4/1981, de 1 de junio, de los estados de alarma, excepción y sitio), pero no estamos en 1934, cuando así se resolvió la insurrección de la Generalitat, sino en 2015 y hoy esa situación es inconcebible dentro de la Unión Europea.

7. Considera que algún tipo de reforma constitucional o estatutaria sería capaz de potenciar la integración de Cataluña, satisfaciendo, cuando menos, a parte de quienes apoyan la opción «soberanista? ¿Querría usted dejarnos constancia de alguna otra reflexión o sugerencia sobre la fase presente de la cuestión catalana?

\section{ENOCH ALBERTÍ ROVIRA}

Creo que el problema fundamental en relación con Cataluña es la ruptura del consenso constitucional sobre su estatuto jurídico-político. Y, en consecuencia, la gran cuestión que se plantea, a mi juicio, es la posibilidad de reconstruirlo. Hoy ello parece muy difícil y, sobre todo, no hay propuestas al respecto formuladas por fuerzas políticas con capacidad para aprobarlas, propuestas que, para ser consideradas por las fuerzas políticas catalanas que hoy sostienen posiciones soberanistas, deberían al menos plantearse sobre la base del reconocimiento nacional de Cataluña y el carácter plurinacional del Estado — ya sin las ambigüedades del texto de 1978-, y de garantías efectivas del autogobierno en los ámbitos de las 
competencias, de la participación en el Estado en asuntos de interés común, de la participación en los asuntos comunitarios europeos, de la presencia internacional y de la financiación.

\section{ROBERTO BLANCO VALDÉS}

Comenzando por la segunda cuestión, deseo dejar claro qué es lo que a mi juicio está hoy de verdad en juego en Cataluña: nada más ni nada menos que la aceptación o no del devastador principio político según el cual una mayoría parlamentaria podría violar la Constitución y las leyes amparándose en la idea, real o supuesta, de que ha recibido un mandato popular al que sólo puede darse cumplimiento efectivo por medio de esa violación. Por decirlo de otro modo, lo que los nacionalistas catalanes han puesto en el primer plano de la política española, con un grado de irresponsabilidad verdaderamente digno de mejor causa, es la contradicción que, según aludía más arriba, destacó con acierto, en su sentencia de 2 de diciembre, el Tribunal Constitucional: una abierta contraposición entre legitimidad democrática y legalidad constitucional en detrimento de la segunda. Siendo así que, como señala con pleno acierto el propio Tribunal, en democracia la legitimidad de las acciones que lleva a cabo el poder público consiste, pues no puede ser de otra manera, en su conformidad a la Constitución y con el resto del ordenamiento jurídico: «En una concepción democrática del poder no hay más legitimidad que la fundada en la Constitución», proclama el Tribunal y es este principio vertebral de la democracia constitucional el que el nacionalismo pretende burlar de un modo absolutamente inaceptable. Aceptar ese desafío a la legalidad constitucional —incluso más, no denunciarlo con la claridad que merece tal abuso- podría suponer para la democracia española el comienzo mismo de su destrucción. Y este, más allá del desafío territorial a la unidad del Estado del nacionalismo catalán, es el más grave problema que hoy tenemos planteado. De que lo resolvamos bien o mal depende, sin duda, no sólo el futuro de España como Estado unido sino el de la propia democracia española como forma civilizada de convivencia de una sociedad pluralista.

Por lo que se refiere a la primera de las cuestiones que plantea la pregunta, he de reconocer que tengo poca confianza en que una reforma constitucional que el nacionalismo catalán (aunque no sólo el catalán) viene exigiendo con el objetivo declarado de facilitar la ruptura del Estado (eso que los nacionalistas llaman la desconexión de Cataluña) puede servir para todo lo contrario: es decir, para integrar a Cataluña. La hipótesis en la que esta última idea se sostiene parte de la convicción de que un cambio constitucional que tuviese por objetivo reacomodar constitucionalmente la posición de Cataluña en el Estado colmaría las aspiraciones políticas de los partidos que se han subido al furioso caballo del secesionismo. Su simple formulación — que resulta en realidad una mera petición de principios-, permite sin embargo comprobar a simple vista que tal supuesto adolece por com- 
pleto de esa condición que es exigible a cualquier propuesta política (de reforma constitucional o de otra clase) que pretenda ser algo más que una manifestación de buena voluntad o de ingenuo ilusionismo: a saber, la coherencia entre los fines que con ella se persiguen y los medios con los que aquellos tratan de alcanzarlos.

Y desde este punto de vista —el de la indispensable coherencia entre los medios y los fines- hay que reconocer que la oferta de revisar la posición constitucional de la que disfruta Cataluña en el conjunto de nuestro Estado federal como llave con la que abrir la puerta de solución al desafío sin precedentes (o, mejor, con el único y trágico precedente de la II República española) planteado a la brava por el independentismo catalán parece todo menos una oferta racional. Pues, en efecto, ¿dónde reside la racionalidad de la presunción de que aceptarán quedarse en condiciones distintas a las actuales quienes (los nacionalistas, que no los catalanes en conjunto) han demostrado sobradamente en los últimos tiempos que sólo están dispuestos a debatir, desde una firme decisión tomada previamente, la forma de marcharse? ¿A través de que razonamiento tortuoso han llegado a su tan berroqueña como gratuita convicción sobre las posibilidades sanadoras de la reforma constitucional respecto de las pretensiones del nacionalismo catalán los partidos y los líderes que defienden que aquella es la única solución al problema suscitado a cara de perro por fuerzas abiertamente secesionistas que actúan sin que les preocupe lo más mínimo la legalidad o la constitucionalidad de sus propuestas?

Estas preguntas, que sorprendentemente nadie se molesta siquiera en contestar, pese a que de su respuesta depende al fin y el cabo la prudencia o imprudencia de meterse en una operación de reforma de nuestra organización territorial que podría crear muchos problemas sin resolver en modo alguno el que la impulsa, no son sin embargo las únicas que suscita una propuesta que presenta otros dos perfiles abiertamente conflictivos. El primero guarda una relación directa con el que he tratado previamente. Y ello porque, disfrutando la Comunidad Autónoma de Cataluña de un grado de autonomía realmente extraordinario, resulta difícil de imaginar cuales podrían ser, llegado el caso, las medidas descentralizadoras adicionales que cabría adoptar sin que aquellas chocasen frontalmente con la cohesión política y económica de la que un Estado digno de tal nombre no puede prescindir. La cuestión, sobre la que tampoco los proponentes de la reforma constitucional suelen decir una palabra, fue suscitada ya con toda la razón, a principios del año 2006, por el Consejo de Estado en un Dictamen sobre la reforma constitucional cuyo extraordinario interés no permite explicar su escaso impacto. Como es bien sabido, sostenía allí el Consejo un juicio con el que concuerdo plenamente: que era «obvio que el ámbito competencial de muchas de nuestras Comunidades está cerca de agotar el campo que el artículo 149 les reserva, cuando no lo ha agotado ya, y que está situación incrementa el riesgo de que una nueva ampliación traspase los límites que este artículo establece». Un juicio que emitía el supremo órgano consultivo del Gobierno pocos meses antes de la adopción del nuevo Estatuto catalán, texto que iba a significar un salto de gran enver- 
gadura en el amplísimo grado de autonomía del que, ya antes de su aprobación, gozaba Cataluña.

No habiendo, pues, terreno sustancial que explorar en esa esfera cuando, de hecho, el recorrido hasta la fecha ha superado en no pocos casos con toda claridad los límites fijados por la Constitución, sólo cabría singularizar la posición de Cataluña — digámoslo con la claridad que no pocos quieren ocultar — asignándole una posición constitucional privilegiada que permitiese a esa Comunidad distinguirse de todas (o de la práctica totalidad) de las demás. Un solo ejemplo, que ya fue hace años manejado, por iniciativa de Pasqual Maragall, originario responsable de la deriva terrible en que hoy estamos: otorgándole un veto sobre la legislación del Estado en un hipotético Senado diferente al actual, veto ese del que disfrutarían Cataluña (y quizá algún otro territorio) pero no la mayoría de las Comunidades españolas.

Esta segunda opción de reforma de nuestra ley fundamental destinada a dejar constancia constitucional de la supuesta singularidad de Cataluña —que, repito, no hay ninguna razón a día de hoy que permita suponer sería aceptada por los secesionistas como una respuesta satisfactoria a las descabelladas pretensiones que vienen desde hace varios años sosteniendo- pondría en el primer plano de la política española otro gravísimo conflicto, que, aunque ha marcado decisivamente la historia de nuestro Estado autonómico, para algunos parece no existir. Me refiero al agravio insoportable - y por tanto, inadmisible-, que los privilegios concedidos eventualmente a Cataluña por vía de reforma constitucional supondrían para las restantes Comunidades españolas, cuyos representantes y ciudadanos no podrían entender que la deslealtad y el desafío a las leyes y la Constitución fueran premiados con concesiones que a los demás se les negarían por haber demostrado justamente lo contrario: el respeto a las leyes y la lealtad constitucional sin los que ningún Estado, descentralizado o no, puede subsistir.

Sin duda hay aspectos importantes de nuestra Constitución necesitados de reforma. Pero meterse en esa compleja operación política y jurídica con la primordial intención de resolver el llamado problema catalán cuando ninguno de los que lo plantean quieren saber nada ni de España ni de su Constitución es una forma evidente de caminar hacia la frustración, en el mejor de los casos, y, en el peor, hacia una irresponsable apertura de la caja de los truenos. En uno u otro supuesto sería, por tanto, muy recomendable extremar la prudencia pues, y parafraseo ahora al gran periodista Henry Mencken, una solución equivocada no constituye jamás una solución.

\section{ENRIC FOSSAS ESPADALER}

Creo que la respuesta a la primera pregunta corresponde solo en parte a los constitucionalistas, que debemos encontrar el lugar adecuado a la hora de proponer soluciones al problema catalán, que es un problema constitucional de España. 
Y ello porque a menudo se lanzan propuestas por parte de los juristas, que no son un ejercicio de Derecho Constitucional (de interpretación de la Constitución), sino de política constitucional, o si se quiere de constitutione ferenda, es decir, en realidad son propuestas políticas que corresponde formular a las fuerzas políticas. Debemos pues ser honestos, y no ofrecer programas políticos como dogmática constitucional. Por otra parte, debemos también ser humildes y saber situarnos en un papel auxiliar de las fuerzas políticas, a las que realmente corresponde adoptar decisiones políticas, y reconocer las limitaciones del Derecho para resolver algo tan complejo como es el problema catalán. Dicho esto, me parece que no solo es legítimo, sino un deber de los constitucionalistas realizar sugerencias, no ocurrencias; valorar técnicamente las propuestas políticas; y aportar soluciones técnicas que sean sometidas a un debate riguroso que, a diferencia de otros países, creo que no se ha dado en España.

Cualquier propuesta debería partir de un buen diagnóstico, y no perder de vista la realidad social y política, que experimenta en estos momentos grandes cambios y con gran rapidez. En este sentido, la actual situación a la que ha conducido el proceso soberanista pone de manifiesto que existen dos propuestas que no constituyen soluciones viables: la primera, conseguir la independencia de Cataluña de forma unilateral y al margen de la ley; la segunda, negar la existencia del problema, rechazar cualquier diálogo, y no ofrecer ninguna respuesta a las demandas de Cataluña. Ya he señalado que a mi juicio no existe «la solución» al problema catalán, y seguro que no existe solo una solución. Y también he apuntado que se requiere tiempo y negociación para llegar a encauzarlo a través de un proceso constitucional, lo cual tampoco asegura un arreglo definitivo, como demuestran el caso de Quebec y Escocia. Eso es algo que deberíamos asumir todos, dentro y fuera de Cataluña: el problema catalán formará parte durante mucho tiempo de la vida política y del debate constitucional de España.

En el momento de responder a esta encuesta el proceso catalán creo que ha llegado a un impasse porque las elecciones llamadas plebiscitarias ni han dado una mayoría de electores a favor de la hoja de ruta independentista, ni han permitido una mayoría parlamentaria para formar gobierno. El proceso, tal como se ha desarrollado hasta hoy, creo que ha sido una acumulación de errores y despropósitos por parte de muchos actores políticos y sociales, y me parece que se deberá reiniciar partiendo de unos planteamientos completamente distintos a los que se han seguido hasta hoy. Sería otro error creer que el proceso está acabado: sin duda va a seguir, pero no por el camino emprendido. En este momento, me parece que existen dos propuestas a tener en cuenta, que no son excluyentes. La primera seria explorar las posibilidades de un referéndum constitucional y acordado, que no podría ser vinculante, en el que se preguntara a los ciudadanos de Cataluña sobre su voluntad de continuar formando parte de España, y al que después siguiera una reforma constitucional. En contra de lo que se sostiene, ello no supondría reconocer ninguna soberanía ni ningún poder constituyente a Cataluña, sino solo conocer la voluntad de los catalanes de forma clara y no mediante instrumentos 
nada fiables como los que se han utilizado hasta hoy. La segunda sería intentar llevar a cabo una reforma constitucional, que incluyera propuestas destinadas a conseguir una mejor integración de Cataluña en una España constitucionalmente distinta, y que debería también ser sometida a referéndum, en este caso del cuerpo electoral español. Esta modificación constitucional debería recoger dos ideas que vengo defendiendo de forma constante desde hace más de veinte años: el reconocimiento constitucional de Cataluña como nación, y una articulación territorial que profundizara en la asimetría federal para conferir un estatuto especial a Cataluña. No hace falta señalar que las dos propuestas presentan en este momento enormes dificultades, esencialmente políticas, y es improbable que prosperen a corto plazo. De ahí que lo que se consiga posiblemente en los próximos meses y años sea solo un apaño para encauzar durante un tiempo el problema catalán.

\section{TERESA FREIXES SANJUAN}

Esta pregunta se responde en la siguiente.

\section{JAVIER GARCÍA FERNÁNDEZ}

En principio, tras el quietismo del Gobierno del Presidente Rajoy, parece necesario que el siguiente Gobierno (si no vuelve a presidirlo el señor Rajoy) debería plantearse una reforma constitucional que tratara de racionalizar el modelo autonómico. El problema reside en que casi cuarenta años de vigencia de la Constitución han creado una fuerte conciencia autonómica en todos los territorios de España, por lo que es muy difícil configurar un régimen especial para una Comunidad Autónoma singular (como podría ser la bilateralidad) sin que esa especialidad no sea reivindicada por otras Comunidades. Y las circunstancias especiales (como el idioma) tienen un recorrido muy corto a menos que se le quiera añadir la cultura, lo que no se debe admitir nunca porque el Estado no puede renunciar a gestionar la cultura común, que existe. A pesar de esas dificultades, es obligado intentar una reforma constitucional y negociar con las fuerzas políticas catalanas no independentistas, negociación que permitiría preparar una reforma del Estatuto de Autonomía.

\section{JOSÉ ANTONIO MONTILLA MARTOS}

Sin duda, la salida a la crisis es la reforma constitucional. A mi juicio, debe tener dos objetivos. Por un lado, resolver los problemas de funcionamiento que han dejado inerme al Estado en este conflicto. Por otro, atender a la situación específica de Cataluña, con el crecimiento del independentismo. En el primer 
sentido, son diversas las reformas que pueden coadyuvar a un mejor funcionamiento del Estado autonómico. En cualquier caso, la más relevante, a mi juicio, es la conversión del Senado en un Consejo territorial, adaptando a nuestras necesidades específicas el modelo del Bundesrat alemán. Cuando repasamos los problemas de funcionamiento del Estado autonómico siempre podemos terminar apelando a la importancia que tendría para abordarlos la existencia de un órgano constitucional de encuentro permanente entre los territorios que pudiera participar en las decisiones del Estado que les afectan. Por ello, no se trata de reformar el Senado para darle más funciones o acercar su composición a las CCAA sino de sustituirlo por un Consejo territorial. Es importante destacarlo pues en el debate sobre la reforma constitucional existe el riesgo de conformarnos con una reforma cosmética del Senado que le dé apariencia de cámara de representación territorial pero no sirva para resolver los problemas de funcionamiento. Pensemos en la legislación básica. En la actualidad es una constante fuente de conflicto que amainaría si lo básico establecido en el Congreso tuviera que ser aceptado también por las regiones en el Consejo territorial. De esta manera podrá producirse un desarrollo más armónico de esas bases estatales en normas autonómicas. Podrá conocerse que normas deberán ser modificadas por ser contrarias a lo básico y que plazo tienen para ello las Comunidades. Y, por supuesto, podría reducirse la conflictividad que ha convertido a nuestro modelo en un auténtico federalismo de conflicto.

El problema de la legislación básica es, seguramente, el que hace más necesaria la creación de un Consejo territorial con facultades en ese ámbito pero no el único. En las relaciones intergubernamentales resulta preciso clarificar el entramado actual de instituciones y procedimientos de relación. La ausencia de un Consejo territorial ha facultado la aparición de diversos lugares de encuentro, de la Conferencia para Asuntos Relacionados con la Unión Europea al Consejo de Política Fiscal y Financiera, con un carácter desformalizado, sin la condición de órgano constitucional, sin poder exigir, por tanto, responsabilidad política e incluso generando en algunos casos inseguridad jurídica. Por otro lado, es evidente la importancia de la participación de las Comunidades en la aprobación de otras leyes como las de financiación autonómica o las de transferencia o en la designación de los miembros de los diversos órganos constitucionales. También la no participación de las Comunidades en el procedimiento de reforma constitucional quedaría cubierta si, pese a no intervenir directamente, el Consejo territorial en el que están presentes tuviera que aprobar esa reforma constitucional.

En todas estas cuestiones, actualmente problemáticas, la existencia de un Consejo territorial garantiza la participación efectiva de los territorios a través de sus órganos de dirección política. Estarían ejerciendo, con ello, el derecho de autodeterminación interna, que es el que corresponde a los pueblos no coloniales ni sometidos a una potencia extranjera, conforme a la legislación internacional.

Pero con ello no se abordaría, obviamente, el problema de Cataluña. En relación a Cataluña la solución más directa sería la inclusión de una cláusula espe- 
cífica en la Constitución. Sin embargo, una fórmula de este tipo difícilmente será aceptada por el resto de territorios en cuanto no será advertida como un modelo diferenciado sino privilegiado. La evolución de nuestro modelo territorial se ha caracterizado por el recelo a la diferenciación en cuanto pudiera conllevar privilegios. Ese fue el origen del rechazo a las consecuencias de la Disposición Transitoria segunda, que quería singularizar a las Comunidades históricas (Cataluña, País Vasco y Galicia) en los orígenes del Estado autonómico.

Por ello, debemos buscar un punto de encuentro aceptable por la mayoría tanto en Cataluña como en el resto de España. Más que en el reconocimiento constitucional de un Estatuto singular para Cataluña éste puede estar en la configuración de un marco flexible que haga posible el desarrollo de las singularidades de cualquier territorio y, por tanto, también de Cataluña. Esto se logra a través de distintos instrumentos jurídico-constitucionales que deben reconocerse en la Constitución: a) En primer lugar, con el reconocimiento expreso de aquellos hechos diferenciales que tienen un sustento objetivo, no estrictamente político. Es el caso de los hechos diferenciales vinculados a la geografía (insularidad), a las tradiciones jurídicas (derecho civil foral) o a la propia cultura (lengua propia); b). En segundo lugar, resulta precisa una clarificación constitucional del reparto competencial que más allá de establecer con claridad las facultades y materias de competencia del Estado deje margen a los territorios para el efectivo ejercicio de su autogobierno. En este sentido, debe ser de competencia exclusiva de la Comunidad Autónoma todo aquello que no afecte a los restantes territorios o al interés general. Esto incluye lógicamente a las cuestiones identitarias; a la organización interna, no sólo institucional sino también territorial y a los aspectos vinculados a sus elementos propios. En relación a las competencias compartidas, supone la garantía del desarrollo de políticas propias por parte de los territorios. Para ello, el criterio de control del desarrollo normativo de unas bases consensuadas en el Consejo territorial es la no contradicción con estas. De esta forma, a partir del mínimo común se pueden producir desarrollos adicionales que pueden ser diferentes; b). En tercer lugar, sostengo la importancia de las leyes orgánicas de transferencia y delegación del artículo 150.2 CE para ese reconocimiento de la singularidad. Es casi un lugar común defender la eliminación de este artículo. Sin embargo, la crítica no está justificada ni atendiendo a la práctica ni a la configuración constitucional de este instrumento. En el primer sentido, hasta aquí se ha hecho un uso moderado del cauce de atribución extraestatutaria de competencias previsto en el artículo 150.2 CE. En realidad, sólo la delegación del tráfico a Cataluña en 2007 sirvió para diferenciar a una Comunidad de las restantes y era una competencia que ya gestionaban País Vasco y Navarra. Pero es que si atendemos a su configuración constitucional, se atribuye el ejercicio, no la titularidad; el Estado puede establecer controles sobre el ejercicio de la facultad competencial delegada y puede revocar la transferencia a través de otra ley orgánica si lo considera necesario. Por tanto, no es el germen de la disolución del Estado. Por el contrario, puede ser un instrumento adecuado para el reconocimiento de singu- 
laridades a determinados territorios en el marco constitucional; sin que conlleve agravios en cuanto ha sido sometido a la aprobación por la representación de la voluntad general tras un debate público; c). Finalmente, en cuarto lugar, podría plantearse en relación a algunas materias actualmente consideradas como compartidas la figura de la legislación divergente, introducida en Alemania con la reforma federal de 2006. Supone que los territorios puedan apartarse de la normativa previa de la Federación, aun cuando ésta puede tener mecanismos para cerrar el paso a esta legislación divergente. Merecería un análisis más profundo pero es evidente que abre una vía constitucional al territorio que quiera desarrollar su singularidad en el marco constitucional.

En fin, a mi juicio, el reconocimiento de la singularidad debe hacerse a través de instrumentos constitucionales a disposición de todos y no mediante una mención singular en la Constitución a Cataluña. La flexibilidad constitucional que haga posible la configuración de un estatuto singular en un marco común puede ser lógica en el contexto actual. La imposición constitucional de un estatus jurídico diferenciado para un determinado territorio resultará difícil de aceptar por los restantes.

\section{MIGUEL SATRÚSTEGUI GIL-DELGADO}

Hay que desechar el pensamiento de que ya es tarde para una solución no traumática al problema catalán. El dictamen, «demasiado poco, demasiado tarde» que en distintas situaciones históricas ha servido para negar validez a las soluciones intermedias, destinadas a preservar los lazos comunes y evitar la independencia, parece completamente inadecuado en este caso. Porque aunque en la actualidad no se ve a mano una solución constitucional que satisfaga a los «soberanistas», mucho más difícil parece que una mayoría de catalanes, suficientemente amplia, apoye una independencia que es inadecuada a las necesidades de la hora presente y que, al plantearse a contracorriente del Derecho, resulta difícilmente viable. En realidad, lo único seguro es lo impredecible de la situación actual (como lo atestiguan las dificultades para formar el gobierno autonómico después de las elecciones del 27 de septiembre). Y lo que se necesita es una aproximación realista y posibilista para conseguir una reforma que puedan respaldar una gran mayoría de españoles y también de catalanes.

Pero no es probable que esa reforma permita incorporar las demandas sustantivas de los nacionalistas, como pueden ser la extensión a Cataluña del régimen fiscal del concierto foral o la inclusión en la Constitución de la posibilidad de celebrar un referéndum de autodeterminación. Para esos cambios, seguramente no habría acuerdo de los grandes partidos españoles. En cambio, tal vez fuera viable una reforma centrada en los aspectos generales de la organización territorial del Estado, con objetivos como los siguientes: simplificar esa organización y reflejarla mejor en el Senado, reconocer de forma más consecuente el plurilingüis- 
mo de España, en especial en el funcionamiento de las Cortes Generales, e incorporar a la Constitución algunos principios del sistema de financiación de las comunidades autónomas, para dotarlo de mayor claridad, equidad y estabilidad.

Y aunque las elecciones generales de 20 de diciembre de 2015 han configurado un parlamento muy fragmentado, no cabe excluir que ese escenario pueda resultar a la postre propicio para alcanzar un acuerdo sobre la reforma constitucional que probablemente sería bien valorado por la ciudadanía, porque hay señales inequívocas de su preferencia por soluciones pactadas, con concesiones recíprocas. En todo caso, un acuerdo de ese tipo aun sería más apreciado si viniese acompañado de políticas económicas y sociales capaces de atender mejor las necesidades de empleo y justicia social presentes en la sociedad española (y en particular en la catalana).

\section{EDUARDO VIRGALA FORURIA}

Hace tiempo que entiendo que la solución definitiva al problema de la integración territorial de Cataluña en España podría ser la realización de una reforma constitucional agravada del artículo 168 de la Constitución para incorporar el derecho de secesión. Y cuanto más se tarde peor será. Puede llegar un momento en que los acontecimientos políticos hagan inevitable la convocatoria de un referéndum de independencia, bien en Cataluña o en Euskadi, o en ambas Comunidades Autónomas, y no exista regulación alguna al respecto. Me situaría en la línea que ha señalado el profesor Wayne Norman, de la Universidad de Duke, de que los más entusiastas partidarios de constitucionalizar el derecho de secesión son académicos con escasa simpatía por la secesión, con la esperanza de que la secesión no se ejerza en la práctica nunca. Coincido también con el citado profesor de Duke en que la constitucionalización de un derecho de secesión puede frenar el propio afán secesionista y, si no, permite la posibilidad de que la secesión se decida democrática y legalmente. Si no hay regulación previa, las respuestas se darán en el momento de intentarse la secesión con los inconvenientes que eso conlleva.

Es cierto que parte de la doctrina constitucionalista comparada entiende que la unidad e indisolubilidad nacional es irreformable, pero nuestro TC ha reiterado que no estamos ante una democracia militante y que la Constitución es reformable en todos sus apartados. Es más, en la sentencia 42/2014, de 25 de marzo, el TC señala que la atribución de soberanía a Cataluña es «una aspiración política a la que solo puede llegarse mediante un proceso ajustado a la legalidad constitucional con respeto a los principios de 'legitimidad democrática', 'pluralismo' y 'legalidad', expresamente proclamados en la Declaración [de soberanía de 2013] en estrecha relación con el 'derecho a decidir'» (FJ 3). En este aspecto hay que partir de la diferencia entre unidad e indivisibilidad. La primera ha de mantenerse siempre (unidad de lo previo y unidad de lo posterior) aunque no la segunda. La soberanía seguiría en manos del pueblo español si decidiera la posible disolubilidad territorial del Estado 
en una reforma constitucional ratificada en referéndum (art. $168 \mathrm{CE}$ ), permitiendo que una Comunidad Autónoma pueda convocar una consulta sobre la independencia, sin que eso impugne ninguno de los principios del constitucionalismo.

No voy a entrar en el debate de si es aceptable o no la secesión desde un punto de vista filosófico, politológico o, incluso, ético. Simplemente, creo que constitucionalmente nada impide una reforma que reconozca el derecho de secesión y que en la situación que vive España es la única solución democrática para mantener la legitimidad de la pertenencia al Estado de los habitantes de determinados territorios. Creo, además, que la regulación del derecho de secesión, al impedir el uso en sentido victimista de los argumentos secesionistas, llevará a que el mismo sólo se ejerza en situaciones límite en que las autoridades de una Comunidad Autónoma estén absolutamente convencidas de ganar un referéndum en sentido independentista. Mientras, el debate secesionista no será un tema cotidiano, con el asentimiento tácito de la pertenencia voluntaria al Estado, que viene de siglos atrás, pero que, con el reconocimiento del derecho de secesión permite afirmar un asentimiento tácito actual y, desde luego, destierra la violencia como arma política.

Propugno, por lo tanto, la convocatoria primero de un referéndum en Cataluña por el Gobierno central, de acuerdo al artículo 92 o previa solicitud del catalán y en el marco de una nueva LO de referéndum que incluya los autonómicos. La pregunta, para que no se vea afectada la soberanía nacional, lo que impide la jurisprudencia constitucional, tendría que versar sobre la voluntad de los catalanes para que se inicien los cambios legales y constitucionales necesarios para poder realizar un definitivo referéndum de secesión.

$\mathrm{Si}$ el resultado en el anterior referéndum fuera positivo a iniciar esos cambios, sería necesaria una posterior reforma constitucional por el procedimiento del artículo $168 \mathrm{CE}$ que estableciera lo que Norman denomina «clausula rigurosa de secesión», es decir, en sus palabras, una clausula más dificultosa que la que los secesionistas aplicarían si pudieran imponerla en solitario. Pero debe hacerse de forma que los independentistas no utilicen continuamente el derecho constitucional de secesión como arma de chantaje, ni los requisitos sean tan elevados que les impida alcanzarlos y se vuelva a la situación previa al reconocimiento del derecho de secesión.

8. Como constitucionalista ¿qué consideraciones quiere aportarnos sobre una bipotética declaración de independencia unilateral por parte del Parlament tras las llamadas elecciones autonómicas plebiscitarias? ¿Y sobre una posible subsiguiente redacción y aprobación de una Constitución catalana?

\section{ENOCH ALBERTÍ ROVIRA}

Como constitucionalista, y más allá de las cuestiones concretas que se puedan presentar en el futuro en el actual proceso político de Cataluña y de las diversas 
hipótesis que se puedan formular, creo que la actual situación plantea cuestiones de interés general sobre las que vale la pena reflexionar, algunas novedosas y otras ya clásicas pero que quizá merezcan un replanteamiento. Entre ellas, naturalmente, la relación entre legalidad y legitimidad democrática, mucho más compleja de lo que se ha sostenido a menudo a lo largo de este proceso; los derechos de las minorías territoriales en el seno de Estados democráticos, cuyas aspiraciones, legítimas, nunca pueden llegar a satisfacerse mediante la regla mayoritaria; la definición, en su caso, de estas minorías de base territorial a las que quepa reconocer como sujetos con capacidad para decidir sobre su estatuto jurídico-político; la forma de resolución de conflictos territoriales en Estados democráticos, cuando no existe un cauce constitucional específico y adecuado para ello; la posibilidad de modificación de fronteras, con la redefinición de los Estados actuales y el nacimiento de nuevos Estados, en el siglo XxI y en un contexto democrático y de respeto de los derechos fundamentales de las personas; $y$, en fin, y entre otras, la posibilidad de modificación de las fronteras estatales existentes en el seno de la Unión Europea, el papel que ésta deba o pueda jugar al respecto y la llamada ampliación interna como resultado del eventual nacimiento de nuevos Estados a partir de los miembros de la Unión. Como se ve, cuestiones todas ellas de gran calado, sobre las que se plantean, al menos, incógnitas, debates y discrepancias importantes y que merecerían una doctrina clara y comúnmente aceptada.

En definitiva, se trata de responder a la cuestión de si los Estados existentes, que son productos históricos, resultan inamovibles en los términos en que se formularon en el pasado, o bien si pueden redefinirse mediante medios democráticos y pacíficos, distintos y mucho más civilizados de los que históricamente se han empleado para ello. Y esto en un contexto nuevo de interdependencia internacional y, en el caso europeo, de integración supranacional, que obliga a redefinir el papel de los Estados, y que propiciaría que los viejos y los nuevos convivieran bajo las mismas estructuras superiores, que, a su vez y necesariamente, deberían también reconfigurarse.

\section{ROBERTO BLANCO VALDÉS}

La extremada complicación de la situación política en Cataluña tras las llamadas elecciones plebiscitarias (comicios que, por cierto, en la medida en que quisieran entenderse de ese modo, perdió el nacionalismo catalán) convierte en muy arriesgado hacer cualquier pronóstico sobre la posible evolución de los acontecimientos. En todo caso, y sea finalmente como fuere, si, tal y como se plantea en la pregunta, llegase a producirse otra declaración unilateral de independencia por parte del Parlament, sucesiva a la ya producida a través de la Resolución 1/XI, considero que la reacción del Estado tendría que ser coherente con la gravedad de tal desafío a la legalidad constitucional. El nacionalismo catalán no puede pretender que su enloquecida carrera hacia el precipicio, es decir, su delirante decisión 
de actuar como si la Constitución y las instituciones encargadas de asegurar su cumplimiento no existieran, no tenga las consecuencias que generaría en cualquier Estado constitucional y democrática digno de tal nombre. Por tanto, reitero, a este respecto, lo que ya antes dejé apuntado: que una alza constante en la apuesta ilegal y vulneradora del Estado de derecho por parte de las instituciones autonómicas de Cataluña acabaría por tener inevitablemente, a la postre, gravísimas consecuencias sobre la propia materialidad del régimen autonómico catalán, que no puede ser utilizado —o mejor, burdamente manipulado- por las referidas instituciones en contra del principio esencial en el que reposa cualquier orden jurídico civilizado: el escrupuloso respeto al principio del imperio de la ley.

En cuanto a la eventual redacción de una Constitución catalana a la que se alude en la pregunta, la hipótesis me parece tan descabellada que sencillamente no soy capaz de imaginar el contexto político que podría posibilitar su elaboración y sucesiva aprobación. Por decirlo de otro modo y, si cabe, con mayor claridad: en el supuesto de que una parte, mayor o menor, del parlamento catalán, se dispusiese a la redacción, primero, y a la ulterior aprobación de un texto que rompería de un modo tan flagrante como dramático el orden constitucional, parece evidente que las instituciones del Estado encargadas de cumplir y hacer cumplir la Constitución pondrían, como es su obligación, todos los métodos legales a su alcance para evitar que tal Constitución pudiese ser redactado y aprobada por un órgano parlamentario que carecería — que carece- de toda competencia para ello. El dramatismo de la situación no sería, por desgracia, incompatible con que España y Cataluña se convirtieran en el hazmerreir del mundo político y jurídico en el que se sitúa nuestro Estado, en el que, he hecho, gran parte de las cosas que vienen sucediendo en Cataluña en los últimos años, como consecuencia de una actuación descabellada e ilegal de la que el nacionalismo catalán es el exclusivo responsable, suponen, dicho en una palabra, un auténtico esperpento. $Y$ es que el nacionalismo catalán se ha empeñado con todas sus fuerzas en convertir a España y, dentro de ella, a la Cataluña moderna que tantos admiramos y queremos, en un inmenso Callejón del Gato, recuerdo de una España que durante años creímos felizmente superada. Una tragedia.

\section{ENRIC FOSSAS ESPADALER}

En el momento de responder la encuesta se han realizado las llamadas elecciones plebiscitarias del pasado 27 de septiembre, a las que ya me he referido, pero no esa hipotética declaración unilateral de independencia, que por supuesto no podría ampararse ni en la Constitución ni en el Derecho internacional. Y en el caso de llevarse adelante, Cataluña no sería reconocida por los Estados de la comunidad internacional y quedaría fuera de las organizaciones internacionales, incluida la UE. Lo que aprobó el Parlament, como he señalado, fue la Resolución $1 / \mathrm{XI}$, sobre el inicio del proceso político en Cataluña como consecuencia de los 
resultados de septiembre de 2015. No se trata de una declaración de independencia sino de otro eufemismo: es lo que he calificado como «declaración de insurgencia» pues proclama el inicio del proceso de creación del Estado catalán en forma de república, la apertura de un proceso constituyente, la desconexión democrática de España, la no supeditación a las instituciones españolas, en particular al TC, y el cumplimiento exclusivamente de las normas emanadas del Parlament. La resolución fue impugnada, suspendida y declarada inconstitucional por la STC de 2 de diciembre de 2015. Esa declaración parlamentaria, prevista en la Hoja de ruta, y acordada después entre Junts pel sí y la CUP, fue un auténtico despropósito y un tremendo error que suscitó el rechazo de la comunidad internacional, puso en máxima alerta a la poderosa maquinaria del Estado, y desencadenó gran inquietud en importantes sectores sociales, así como en muchos ciudadanos de Cataluña, incluso entre los votantes de las opciones independentistas. Estos efectos negativos de la Declaración, junto a la imposibilidad de formar un gobierno en Cataluña tres meses después de las elecciones del 27 de septiembre, han situado el proceso soberanista en un punto muerto y han abierto una nueva etapa presidida por la incertidumbre, que también marca el panorama político español tras los resultados de las elecciones generales del 20 de diciembre.

\section{TERESA FREIXES SANJUAN}

Los dos grupos secesionistas con que cuenta el Parlament de Cataluña, Junts pel Sí (JxS, formado por Convergencia, Esquerra Republicana, independentistas no adscritos a partidos y antiguos miembros de Iniciativa) y la Candidatura d'Unitat Popular (la CUP, que se proclaman antisistema), presentaron una propuesta de resolución para que fuera votada, como así sucedió, en el primer pleno que realizara el nuevo Parlament recién elegido. Frente a ello, los diputados de los tres partidos políticos claramente contrarios a la secesión de Cataluña, el Partido Socialista de Cataluña (PSC), el Partido Popular (PP) y Ciudadanos, presentaron recurso de amparo ante el Tribunal Constitucional, por entender que sus derechos fundamentales han sido vulnerados, ya que la decisión de la Mesa admitiendo la propuesta había sido tomada sin que su participación hubiera sido legalmente posible y efectiva; el Tribunal Constitucional ha admitido a trámite, por unanimidad, tal recurso. Además, Ciudadanos y el PP solicitaban también, como medida cautelar, que el Tribunal suspendiera la realización del mencionado pleno, pero éste ha considerado, también por unanimidad, que no procedía tal suspensión.

Por otra parte, la resolución aprobada por el Parlament, ha sido también objeto de recurso ante el Tribunal Constitucional, como acto no legislativo de una Comunidad Autónoma, recurso que ha sido admitido a trámite por el Tribunal, asimismo por unanimidad, con la automática e imperativa suspensión que impide jurídicamente poner en marcha el contenido de tal resolución. 
Con este panorama, se impone hablar claro. Se impone un análisis riguroso que muestre sin paliativos las intenciones de quienes dicen, melifluamente, que lo único que van a decidir es el inicio de un proceso que llevará a la independencia derivada de un «mandato democrático» (otra vez las comillas) expresado en las urnas, en las pasadas elecciones al Parlamento de Cataluña.

Hablemos, pues, claro. Punto por punto.

— Lo que pretenden JxS y la CUP (grupo antisistema que tiene en sus manos la investidura del President de la Generalitat), que siguen en todos sus términos el Full de Ruta adoptado por la denominada «Assemblea Nacional Catalana» (organización social independentista que ha sido punta de lanza en las movilizaciones en favor de la independencia), no puede ser calificado más que como un golpe de Estado. Efectivamente, en la propuesta de resolución: «Se declara solemnemente el inicio de creación del estado catalán independiente en forma de república». No existe ninguna base legal, interna o internacional, que pueda fundamentar tal declaración. Ello consiste en una mera vía de hecho golpista, al margen de cualquier fundamento jurídico, contraria a la Constitución que democráticamente adoptamos los catalanes, junto con el resto de españoles, en 1978.

- La resolución es radicalmente contraria al ejercicio democrático de la soberanía nacional, que la Constitución atribuye al pueblo español, pues pretende atribuir la titularidad de la soberanía y del poder constituyente al Parlament, proclamando al mismo tiempo la apertura de un proceso constituyente para adoptar una constitución catalana.

- En la resolución se insta al gobierno catalán que emane del flamante Parlament a que en el plazo de 30 días inicie la tramitación de tres leyes que el Full de Ruta del secesionismo considera indispensables para la «desconexión» de España: la del proceso constituyente, la de la seguridad social y la de la hacienda pública. Ello implica la rápida presentación de sendos proyectos legislativos al respecto. Además, el Govern queda supeditado al cumplimiento, en exclusiva, de las normas y resoluciones adoptadas por el presente Parlament, con la finalidad de «blindarse» ante las de procedencia española.

- El Parlament, por su parte, queda también sujeto a la acción golpista, puesto que no se supeditará a las instituciones españolas ni, sobre todo, a las decisiones del Tribunal Constitucional.

La declaración de inconstitucionalidad emitida sobre esta resolución aprobada por la mayoría secesionista del Parlament no ha generado ningún apaciguamiento de la situación. Los dos grupos secesionistas, JxS y la CUP no tienen intención de respetarla. JxS, en boca del President de la Generalitat en funciones ha declarado que si bien el TC se ha pronunciado jurídicamente, ello nos les vincula 
políticamente, por lo que el proceso de independencia continúa. La CUP ha reclamado desobedecer directamente al Tribunal Constitucional.

El problema con el que se encuentran es con que no han conseguido, todavía, estas dos formaciones, llegar a un acuerdo de investidura para formar el Govern de la Generalitat y, por lo tanto, los mandatos que se le hacen no pueden ser cumplidos por ahora. Llevan más de dos meses «negociando» sobre ello y los auspicios no parecen llevar a buen puerto, por la oposición de la CUP a investir al President en funciones y porque este partido impone unas condiciones a la investidura que rebasan el marco constitucional e, incluso, el europeo. Aunque $\mathrm{JxS}$ ofrece seguir con el proceso de independencia y, concretando, el inicio de la redacción de una Constitución para una República Catalana, que llevaría a la independencia en 18 meses desde la investidura del nuevo President, la postura de la CUP no está clara al respecto, pues depende de lo que sus bases decidan en asamblea en próximas fechas. Si el 11 de enero no se cuenta con un President investido, estaremos, otra vez, ante nuevas elecciones autonómicas.

Todo ello, en un contexto general altamente complicado, tras las elecciones generales del 20 de diciembre de 2015, en las que el Congreso de los Diputados ha quedado fragmentado, sin mayoría absoluta para ningún partido y con grandes dificultades para obtener una mayoría que permita la investidura en un tiempo razonable. La posición de algunos partidos políticos de ámbito español, como Podemos y sus aliados y lo que queda de Izquierda Unida, favorables a la realización de un referéndum de autodeterminación en Cataluña, habida cuenta de los resultados obtenidos en estas elecciones, no facilita tampoco la realización de acuerdos para la formación de un gobierno estable en España.

Por otra parte, aparece también el tema de si una hipotética reforma constitucional, seguida de un nuevo Estatuto de Autonomía para Cataluña (ésta es la posición del Partido Socialista, asumida también por el Partit Socialista de Catalunya) podría desbloquear la situación. Ello está muy en el aire, porque tras las pasadas elecciones generales, el Partido Popular cuenta sobradamente con la minoría de bloqueo, pues ha obtenido 123 diputados y el bloqueo se sitúa en los 117. Ello puede, por una parte, petrificar la situación, lo cual no creo que resolviera ningún problema. Pero, esto es positivo, garantiza que la reforma constitucional tenga que ser realmente de consenso y que no se pudiera repetir lo que sucedió con el Estatuto catalán de 2006, adoptado contra el PP.

¿Quedarían los secesionistas satisfechos con esta reforma constitucional? Evidentemente no, salvo que digan «diego» donde dijeron «digo». Al menos, por ahora, tanto la antigua Convergencia Democrática de Cataluña, como Esquerra Republicana de Catalunya y la CUP han manifestado que ellos no están en esta línea, que la reforma constitucional no va con ellos y que su «hoja de ruta» hacia la independencia continúa plenamente en vigor.

Tenemos, pues, ahora mismo, cuando redacto estas líneas, dos gobiernos en funciones, en España y en Cataluña y un horizonte que, según declaraciones de diversos líderes políticos, no descarta nuevas elecciones en ninguno de los dos 
casos. Si no se impone la cordura y la razonabilidad, así como un mínimo sentido de Estado por parte de los partidos políticos, ese horizonte no es nada diáfano y anticipa tormentas poco edificantes. Ojalá que ello no sea así y que cuando estas líneas vean la luz, el escenario ya sea distinto. Lo digo por la rapidez con la que se suceden acontecimientos en estos tiempos.

\section{JAVIER GARCÍA FERNÁNDEZ}

La respuesta a la primera declaración de independencia está en la Sentencia constitucional de 2 de diciembre de 2015. Todo acto formalizado del Parlamento o del Gobierno de Cataluña para iniciar la redacción de una Constitución ha de ser recurrido también ante el Tribunal Constitucional y, de persistir, debería aplicarse el artículo 155 suspendiendo incluso al Presidente de la Generalidad o a los Consejeros que participaran en la preparación de un texto constitucional. Insisto, sin embargo, en que sólo se deben atacar los actos formalizados, no la multitud de elucubraciones que producen los independentistas.

\section{JOSÉ ANTONIO MONTILLA MARTOS}

Apenas nada que decir. La Resolución 1/XI supone la declaración solemne del inicio del proceso de secesión. A partir de ahí cualquier actuación deberá ser recurrida con las consecuencias administrativas e incluso penales que procedan. Esto provocará un agravamiento de la crisis política. Es necesario que ambas partes dialoguen pero teniendo en cuenta que el campo de juego es el marco constitucional, susceptible de reforma, obviamente, pero siempre a través de los procedimientos constitucionalmente establecidos. La DUI, o su versión edulcorada de inicio del proceso de secesión, supone la pérdida de cualquier atisbo de legitimidad tanto interna como externa para los impulsores del proceso de secesión.

\section{MIGUEL SATRÚSTEGUI GIL-DELGADO}

En mis respuestas a las preguntas anteriores creo haber contestado también a esta última.

\section{EDUARDO VIRGALA FORURIA}

Si la mayoría del Parlamento de Cataluña aprobara una Declaración unilateral de independencia (DUI), entraría en juego, en primer lugar, el TC, ya que el Gobierno central impugnaría tal Declaración. A partir de ahí, las incógnitas son 
muchas. La Declaración quedaría suspendida (art. 161.2 CE) y habría que ver la reacción de las instituciones catalanas a tal suspensión (y muy probablemente una final declaración de inconstitucionalidad).

Si hubiera resistencia a aceptar la suspensión automática y se pretendiera actuar fuera del marco constitucional, entraría en juego el nuevo artículo 92 LOTC (Ley Orgánica 15/2015, de 16 de octubre, de reforma de la Ley Orgánica 2/1979, de 3 de octubre, del Tribunal Constitucional, para la ejecución de las resoluciones del Tribunal Constitucional como garantía del Estado de Derecho), necesario tras lo sucedido el 9 de noviembre de 2014. El TC no tiene policía judicial y, hasta ahora, tampoco la posibilidad de emitir una orden de ejecución. Y no parece que, como atinadamente ha explicado E. Gimbernat en El Mundo (19 de septiembre de 2015), pueda dejarse todo a un hipotético proceso penal por el delito de desobediencia, tanto por los plazos en los que se mueve ese proceso como por las dificultades del tipo de desobediencia en su entendimiento por el TS. Ahora puede ya acordarse «la suspensión en sus funciones de las autoridades o empleados públicos de la Administración responsable del incumplimiento, durante el tiempo preciso para asegurar la observancia de los pronunciamientos del Tribunal» (art. 92.4.b LOTC). Si lo anterior no fuera suficiente, procedería la aplicación del artículo 155, en lo que me remito a la respuesta a la sexta pregunta.

Sobre el fondo, y por lo expuesto con anterioridad, una DUI es imposible jurídicamente en el actual ordenamiento constitucional español, como el propio Consell Assesor per a la Transició Nacional ha reconocido diciendo que «no se ajusta a las disposiciones del ordenamiento constitucional español» (p. 151). Es cierto que el Derecho internacional no tiene una respuesta codificada ante el intento de un territorio de independizarse de facto, pero, desde luego, no reconoce el derecho a proclamar una DUI ni aunque esté basada en un referéndum en el que esa opción haya sido mayoritaria. No puede traerse como respaldo el caso de Kosovo, en el que el marco constitucional considerado por la Corte Internacional de Justicia (22 de julio de 2010) no fue la Constitución de Serbia sino la Resolución del Consejo de Seguridad de la ONU 1244 (1999), que establecía un régimen interino de autogobierno. Lo que la Opinión de la Corte Internacional de Justicia dice con claridad es que «es enteramente posible que un acto en particular, como una declaración unilateral de independencia, no infrinja el derecho internacional sin que necesariamente constituya el ejercicio de un derecho que éste le confiere» (párr. 56). Eso es verdad en el caso de Kosovo, pero, también, que, como ha señalado A. Mangas ( Cataluña: ¿habrá independencia?», en El Cronista del estado social y democrático de derecho, n. $\left.{ }^{\circ} 42,2014\right)$, se trata de un «un caso excepcional, único, sui generis, especial (estas adjetivaciones se repiten por doquier en las Exposiciones escritas de los Estados), caso que no creaba precedente debido a los antecedentes del conflicto (intervención de la OTAN), la naturaleza del mismo, la prolongada administración internacional del territorio, la comunidad internacional involucrada y el 'intenso y largo esfuerzo’ para una solución negociada». El problema, 
además, como ha planteado J. Vidmar («Unilateral Declaration of Independence in International Law», en D. French, Statehood and Self-Determination, Cambridge: Cambridge University Press, 2013), es que tampoco hay consenso sobre cuándo, tras una DUI, hay un reconocimiento de facto de un nuevo Estado a nivel internacional: no hay mínimo fijado de Estados, ni parece ser suficiente el reconocimiento de los grandes Estados.

Sobre una hipotética Constitución catalana solo cabe imaginar dos hipótesis. La primera, una Constitución ilegal posterior a una DUI, que seguiría la suerte de ésta, es decir, la suspensión y posterior declaración de inconstitucionalidad. La otra, una Constitución federada en el marco de un Estado federal, previa reforma vía artículo 168 de la Constitución de 1978, aunque me pregunto qué ventajas aportaría un cambio federal de la forma de Estado territorial. No conozco ninguna técnica federal que sea inaplicable en el Estado autonómico. Por el contrario, el diseño de 1978, asimétrico y capaz de absorber una singularidad de tanto calado como la foral, es más dúctil de lo que puede ser un Estado federal. Incluso una reforma constitución podría establecer la aprobación directa de los Estatutos sin ratificación en las Cortes, pero con control de constitucionalidad.

$* * *$

Title: Academic survey about Catalonia

ABSTRACT: In this academic survey a group of Constitutional Law Professors answer some questions about the political and legal situation on Catalonia and the constitutional challengues that must be faced; specifically about the legal position of Catalonia in Spain, the movement for Independence of Catalonia, the right to decide, the "Estatuto de Autonomia» of Catalonia and the posibility of a constitutional reform.

Resumen: En esta encuesta un grupo de Catedráticos de Derecho Constitucional contestan un conjunto de preguntas sobre la situación jurídico-politica en Cataluña y los desafíos constitucionales que plantea, especialmente en lo relativo a la posición de Cataluña en el Estado autonómico español, el movimiento independentista, el derecho a decidir, el Estatuto de Autonomía de Cataluña y la posibilidad de una reforma constitucional.

KEY WORDS: Spanish territorial organisation, Catalonia, movement for Independence, right to decide, Estatuto de Autonomía.

Palabras Clave: Organización territorial del Estado español, Cataluña, movimiento independentista, derecho a decidir, Estatuto de Autonomía. 